\author{
UNIVERSIDADE DE BRASÍLIA - UNB \\ FACULDADE DE CIÊNCIAS DA SAÚDE - FS \\ PROGRAMA DE PÓS-GRADUAÇÃO EM ENFERMAGEM - PPGENF
}

ROBERTO NASCIMENTO DE ALBUQUERQUE

\title{
AS NECESSIDADES ESPIRITUAIS NO CUIDADO DE ENFERMAGEM: UM ESTUDO À LUZ DA TEORIA TRANSPESSOAL DE JEAN WATSON
}

Dissertação apresentada como requisito parcial para obtenção do título de Mestre em Enfermagem pelo Programa de Pós-Graduação em Enfermagem da Universidade de Brasília.

Área de Concentração: Políticas, Práticas e Cuidado em Saúde e Enfermagem.

Linha de Pesquisa: Processo de Cuidar em Saúde e Enfermagem.

Orientadora: Prof. ${ }^{a}$ Dr $^{a}$ Moema da Silva Borges

BRASÍLIA - DF

2015 
ROBERTO NASCIMENTO DE ALBUQUERQUE

\title{
AS NECESSIDADES ESPIRITUAIS NO CUIDADO DE ENFERMAGEM: UM ESTUDO À LUZ DA TEORIA TRANSPESSOAL DE JEAN WATSON
}

\begin{abstract}
Dissertação apresentada como requisito parcial para a obtenção do título de Mestre em Enfermagem pelo Programa de Pós-Graduação em Enfermagem da Universidade de Brasília.
\end{abstract}

Aprovado em 28 de agosto de 2015.

BANCA EXAMINADORA

Professora Doutora Moema da Silva Borges - Presidente da Banca

Universidade de Brasília - Campus Darcy Ribeiro

Professora Doutora Ivone Kamada - Membro Efetivo

Universidade de Brasília - Campus Darcy Ribeiro

Professora Doutora Janaína Meirelles Sousa - Membro Efetivo

Universidade de Brasília - Campus Ceilândia

Professora Doutora Diana Lúcia Moura Pinho - Membro Suplente

Universidade de Brasília - Campus Darcy Ribeiro 
A todos os pacientes que clamam por profissionais mais atenciosos $e$ que esses pacientes sejam vistos além da doença, além de um procedimento. Vocês foram e sempre serão a inspiração dos meus cuidados de enfermagem. 


\section{AGRADECIMENTOS}

A Deus, inteligência suprema, causa primária de todas as coisas.

Aos meus pais, por sua capacidade de acreditar e investir em mim. Mãe, seu cuidado e sua dedicação foram a esperança e o incentivo para seguir. Pai, sua presença significou a segurança e a certeza de que não estou sozinho nesta caminhada. Minhas saudades eternas e o meu amor mais profundo.

Aos meus irmãos, José Herculano, Denise e Daisy, que nunca deixaram de acreditar em mim e no meu potencial. Obrigado pela paciência, pelo incentivo, pela força e, principalmente, por todo o carinho. Esta vitória também é de vocês!

Aos meus sobrinhos, Ana Carolina, Brunno, Carla Desirée, Maria Clara, Mariana, Rodrigo, Marina, Alexia, Ana Gabriela, que estiveram próximos a mim, fisicamente e/ou emocionalmente, fazendo esta vida valer cada vez mais a pena. Amo todos vocês!

Juca e Jullie, "papai” ama vocês!

Aos meus familiares e "agregados", meu muito obrigado!

Ao Danilo, que de forma especial e atenciosa me deu força e coragem desde o início desta caminhada. Ao Stone, que me incentivou e cuidou dos meus passos nas últimas semanas desta jornada. Meu muito obrigado!

Aos meus amigos, pelas alegrias, tristezas e angústias compartilhadas. Com vocês, as pausas entre um parágrafo e outro de produção me trouxeram muita paz e alegria.

Aos meus alunos, pessoas com quem amo partilhar a vida. Com vocês me sinto vivo de verdade. Obrigado por cada olhar, cada sorriso, cada abraço que recebo todos os dias. Tudo isso me traz paz na correria de cada semestre e a certeza de que estou no caminho certo. 
À Universidade de Brasília, onde aprendi a refletir, questionar e nunca encarar a realidade como pronta. Aqui aprendi a ver a vida de uma maneira diferente. Sou grato desde a minha graduação.

Ao curso de Enfermagem, que me ensinou a ver o ser humano de uma maneira holística, de verdade. Ensinou-me a perceber que exerço uma das mais belas profissões; que cuidar de alguém vai além de uma profissão, é um estilo de vida.

Às professoras Dra. Ivone Kamada, Dra. Janaína Meirelles Sousa e Dra. Diana Lúcia Moura Pinho que puderam fazer parte deste momento tão importante da minha vida e que compartilharam suas experiências e vivências neste campo tão importante que é a espiritualidade na saúde.

Aos meus professores e colegas do mestrado, pessoas com quem convivi nesses dois últimos anos. Obrigado pelas risadas, companheirismo e troca de conhecimentos.

E, por fim, a minha orientadora e companheira de sonho, professora Dra. Moema da Silva Borges. Agradeço, do fundo do meu coração, por mais de quinze anos de amizade e companheirismo. Obrigado pela persistência, pela dedicação, pelo desempenho, pelo profissionalismo, pelos puxões de orelha, pelo respeito e pela competência durante essa longa jornada. Muito do que sou como pessoa e profissional devo a você! 
Como reconciliar, ligar, ou seja, o que diz respeito ao corpo e ao espírito, em ligação com os danos fisiológicos, as concepções e símbolos culturais, com a racionalidade dita científica. É este todo o problema e o desafio dos cuidados. 


\section{Resumo}

ALBUQUERQUE, R. N. As necessidades espirituais no cuidado de enfermagem: um estudo à luz da Teoria Transpessoal de Jean Watson. 2015. 105 f. Dissertação (Mestrado em Enfermagem) - Departamento de Enfermagem, Faculdade de Ciências da Saúde, Universidade de Brasília, Brasília, 2015.

Nos últimos anos, pesquisas no âmbito da saúde têm apontado que a fé e a esperança representam aspectos imprescindíveis para a apreensão do processo de recuperação da saúde e o enfrentamento das doenças. Dessa forma, a espiritualidade tem se configurado como uma variável relevante na composição do indicador de saúde na busca da promoção de um cuidado integral. Objetiva-se, nesta pesquisa, analisar as vivências de enfermeiros e pacientes acerca da abordagem da dimensão religiosa/espiritual nos cuidados de enfermagem com vistas a sua integralidade, à luz da Teoria Transpessoal do Cuidado de Jean Watson. Trata-se de uma pesquisa exploratória, descritiva, de abordagem qualitativa, realizada com enfermeiros e pacientes de um hospital universitário do Distrito Federal. Foram realizadas entrevistas a partir de um roteiro semiestruturado no período de agosto e setembro de 2014. A análise do conteúdo do corpus gerado foi realizada com auxílio do software Alceste. Da análise dos resultados das entrevistas dos enfermeiros, emergiram dois eixos. O primeiro eixo, Formação Profissional, apontou uma lacuna na formação do profissional enfermeiro em relação aos cuidados frente à dimensão espiritual. No segundo eixo, Desafios e Possibilidades para o Cuidado Integral, emergiram duas categorias que assinalam os fatores que impedem a prática do cuidado espiritual e as possibilidades para a prática dos mesmos. Em relação à análise de conteúdo das entrevistas com os pacientes, emergiram também dois eixos. O primeiro, denominado Suporte Terreno, foi composto pelas categorias: a travessia pessoal, a travessia com a família e os outros ajudantes na travessia e fazem referência ao caminho trilhado pelos pacientes ao longo do diagnóstico da doença-internação-tratamento-cura. $\mathrm{O}$ segundo eixo, denominado Suporte Divino, relata o papel do sagrado na busca do enfrentamento da doença. Esse eixo foi composto pelas categorias: as fontes do Sagrado, os enviados do Sagrado e Deus - a fonte da fé. Os resultados apontam que é importante que as instituições formadoras e promotoras do cuidado de enfermagem rompam com a lógica capitalista de organização de serviços e formação profissional. Além disso, os enfermeiros devem estar atentos para a dimensão espiritual de seus pacientes. Os cuidados de enfermagem para essa dimensão devem contemplar ações voltadas para a integralidade do ser humano, priorizando tanto o Suporte Terreno quanto o Suporte Divino. Assim, torna-se necessário considerar a complexidade da natureza humana, incluir as discussões filosófico-espirituais no plano de cuidado de enfermagem e resgatar a essência do cuidado de enfermagem. A enfermagem precisa se mover para além do objetivável, do cientificismo, da preocupação extenuante com a técnica. É o momento do enfermeiro se dedicar às verdades ocultas, desenvolver novos conhecimentos que fomentem a discussão da dimensão espiritual e sua importância no âmbito do cuidado integral de enfermagem; significa buscar uma nova maneira de cuidar do outro numa sociedade que se recusa a valorizar esse cuidar.

Palavras-chave: Espiritualidade; Integralidade em saúde; Enfermagem; Teoria de enfermagem. 


\begin{abstract}
In recent years, health surveys have pointed out that faith and hope represent essential aspects for the apprehension of the health recovery process and confront the disease. Thus, spirituality has been configured as a relevant variable in the composition of the health indicator in the pursuit of promoting a comprehensive care. The objective this research is analyze experiences of nurses and patients about the religious/spiritual dimension approach in nursing care with a view of Transpersonal Care Theory of Jean Watson. It is an exploratory, descriptive, qualitative approach, performed with nurses and patients of a university hospital in the Federal District, Brazil. The interviews were conducted from a semi-structured between August and September 2014. The analysis of the corpus generated content was performed using the software Alceste. Analyzing the results of interviews with nurses, two axes emerged. The first axis, Vocational Training, pointed out a gap in nursing professional education in relation to the spiritual dimension. In the second axis, Challenges and Possibilities for Integral Care, two categories emerged that indicate the factors that impede the practice of spiritual care and the opportunities to practice them. Regarding the content analysis of interviews with patients also emerged two axes. The first, called Ground Support was composed by categories: a personal journey, the journey with the family and other helpers in the journey and reference the path taken by patients during the diagnosis of the disease-hospitalization-treatment-cure. The second axis, called Divine Support, reports the role of the Sacred in the pursuit in fighting the disease. This axis is composed of the categories: the Sacred supplies, the envoys of the Sacred and God - the source of faith. The results show that it is important that educational institutions and promoters of nursing care break with the capitalist logic of organizing services and vocational training. In addition, nurses should be aware of the spiritual dimension of their patients. Nursing care for should include actions for the completeness of the human being, emphasizing both the Ground Support as the Divine Support. Therefore, it is necessary to consider the complexity of human nature, include the philosophical and spiritual discussions in nursing care plan and rescue the essence of nursing care. Nursing needs to move beyond the objectifiable, of scientism, of strenuous concern with the technique. It is time nurses devote to hidden truths, develop new skills that foster discussion of the spiritual dimension and its importance within the whole nursing care; It means seeking a new way of caring for others in a society that refuses to value this care.
\end{abstract}

Keywords: Spirituality; Integrality in Health; Nursing; Nursing Theory. 


\section{Resumen}

En los últimos años, las investigaciones en salud han señalado que la fe y la esperanza representan aspectos esenciales para la aprehensión del proceso de recuperación de la salud y enfrentar la enfermedad. Por lo tanto, la espiritualidad se ha configurado como una variable relevante en la composición del indicador de salud en la búsqueda de la promoción de una atención integral. El objetivo de esta investigación es analizar las experiencias de los enfermeros y los pacientes sobre el enfoque de la dimensión religiosa/espiritual en la atención de enfermería, con miras a su totalidad a la luz de la Teoría Transpersonal de la Atención de Jean Watson. Es un estudio exploratorio, com enfoque descriptivo, cualitativo, realizado con los enfermeros y los pacientes de un hospital universitario en el Distrito Federal, Brasil. Se realizaron entrevistas a partir de um guión semiestructurado entre agosto y septiembre de 2014. El análisis de los contenidos generados fue realizado a partir del software Alceste. Analizando los resultados de las entrevistas con los enfermeros, surgió dos ejes. El primer eje, Formación Profesional, señaló uma brecha en la educación professional en enfermería en relación con el cuidado con la dimensión espiritual. En el segundo eje, Desafíos y Posibilidades de Atención Integral, emergieron dos categorías que indican los factores que impiden la práctica del cuidado espiritual y las oportunidades para practicar ellos. En cuanto al análisis de contenido de las entrevistas con los pacientes también surgió dos ejes. El primero, llamado de Apoyo en Tierra, fue compuesta por tres categorías: un viaje personal, el cruce con la familia y otros ayudantes en el cruce que hacen referencia a la ruta tomada por los pacientes durante el diagnóstico de la enfermedad, la hospitalización, el tratamiento y la cura. El segundo eje, llamado Apoyo Divino, informa el papel del Sagrado en la lucha contra la enfermedad. Este eje se compone de las categorías: las fuentes del Sagrado, los enviados del Sagrado y Dios - la fuente de la fe. Los resultados muestran que es importante que las instituiciones educativas y promotoras de la atención de enfermería puedan romper con la lógica capitalista de la organización de los servicios y de la formación profesional. Además, los enfermeros deben estar conscientes de la dimensión espiritual de sus pacientes. La atención de enfermería debe incluir acciones para la integridad del ser humano, priorizando tanto el apoyo en la tierra como el apoyo. Es necesario tener en cuenta la complejidad de la naturaleza humana, incluir las discusiones filosóficas y espirituales en el plan de cuidados de enfermería y rescatar la esencia de los cuidados de enfermería. Enfermería tiene que ir más allá del objetivable, del cientificismo, de la preocupación extenuante con la técnica. Es tempo de los enfermeiros dedicarsen a las verdades ocultas, desarrollar nuevas habilidades que fomentan la discusión de la dimensión espiritual y su importancia dentro de toda la atención de enfermería; Esto significa la búsqueda de una nueva forma de cuidar a los demás en una sociedad que se niega a valorar esta atención.

Palabras clave: Espiritualidad; Integralidad en salud; Enfermería; Teoría de enfermeria. 


\section{LISTA DE FIGURAS}

Figura 1. Dendograma com os eixos e categorias que emergiram da análise das entrevistas dos enfermeiros. Brasília, 2014. 54

Figura 2. Dendograma com os eixos e categorias que emergiram da análise das entrevistas dos pacientes. Brasília, 2014. 


\section{LISTA DE TABELAS}

Tabela 1. Perfil dos enfermeiros que atuam no cenário da pesquisa. Brasília, 2014..............52

Tabela 2. Perfil dos pacientes que participaram da pesquisa. Brasília, 2014 ..........................75 


\section{LISTA DE QUADROS}

Quadro 1. Distinção entre Religião e Espiritualidade..........................................................28

Quadro 2. Fatores para investigação, perguntas e abordagens da dimensão

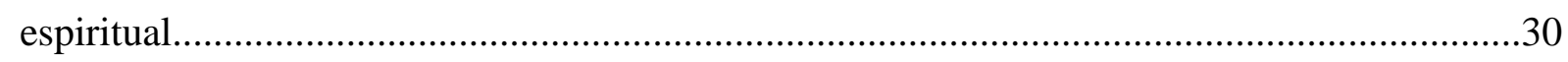

Quatro 3. Comparativo entre o Caritative Factors e o Clinical Caritas Process.....................43

Quadro 4. Aspectos importantes para um ambiente de cura...................................................64 


\section{LISTA DE SIGLAS}

AC - Análise de Correspondência

BMMRS-p - Brief Multidimensional Measure of Religiousness and Spirituality

CHD - Classificação Hierárquica Descendente

COFEN - Conselho Federal de Enfermagem

CRE - Coping Religioso-Espiritual

EBSERH - Empresa Brasileira de Serviços Hospitalares

FIOCRUZ - Fundação Oswaldo Cruz

HUB - Hospital Universitário de Brasília

IBGE - Instituto Brasileiro de Geografia e Estatística

INCA - Instituto Nacional do Câncer

NANDA - North American Nursing Diagnosis Association

OMS - Organização Mundial de Saúde

QV - Qualidade de Vida

SAE - Sistematização da Assistência de Enfermagem

SUS - Sistema Único de Saúde

TCLE - Termo de Consentimento Livre Esclarecido

UCE - Unidades de Contexto Elementar 


\section{SUMÁRIO}

APRESENTAÇÃO_............................................................................... 17

INTRODUÇÃO ............................................................................ 19

$\begin{array}{ll}\text { Objetivo Geral } & 20\end{array}$

$\begin{array}{ll}\text { Objetivos Específicos } & 20\end{array}$

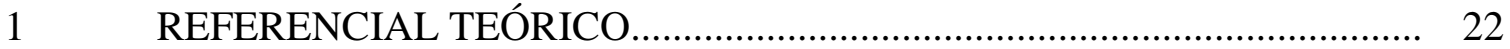

$1.1 \quad$ A INTEGRALIDADE E SUAS POLISSEMIAS ..................................... 22

1.2 A INTEGRALIDADE NO CUIDADO EM SAÚDE................................. 24

1.2.1 As dimensões do ser humano e a importância da dimensão espiritual no cuidado em saúde.

1.2.2 Distinção entre espiritualidade e religiosidade...................................... 26

1.2.3 A dimensão espiritual na perspectiva da integralidade e dos cuidados de saúde e de enfermagem............................................................... 28

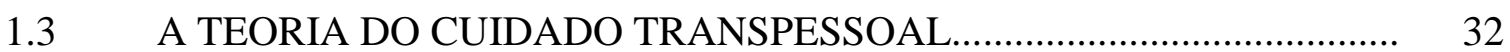

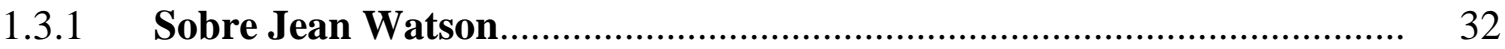

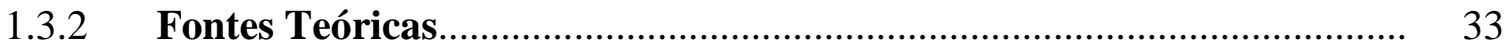

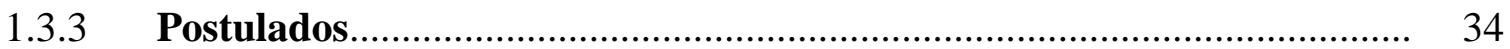

1.3.4 Marco filosófico e conceitual da Teoria do Cuidado Transpessoal.......... 34

1.3.5 Definição operacional dos principais conceitos...................................... 35

1.3.6 O poder do campo energético no cuidado transpessoal........................... 38

1.3.7 Caritative Factors/Clinical Caritas Process ................................................ 40

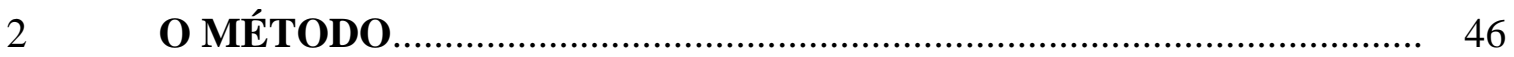


$2.1 \quad$ TIPOLOGIA DO ESTUDO............................................................... 46

$2.2 \quad$ SUJEITOS DO ESTUDO...................................................................... 47

2.3 LOCAL DO ESTUDO...................................................................... 47

$2.4 \quad$ CRITÉRIOS DE INCLUSÃO_................................................................ 47

2.5 CRITÉRIOS DE EXCLUSÃO............................................................. 47

2.6 PROCEDIMENTOS DE COLETA DE DADOS......................................... 48

$2.7 \quad$ PROCEDIMENTO DE ANÁLISE.......................................................... 49

$2.8 \quad$ PROCEDIMENTOS ÉTICOS .......................................................... 50

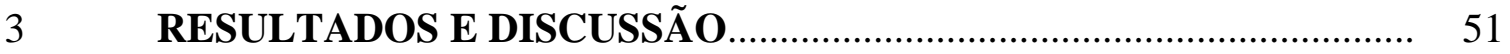

3.1 PERFIL DOS ENFERMEIROS......................................................... 51

3.2 VIVÊNCIA DOS ENFERMEIROS FRENTE À ESPIRITUALIDADE........ 53

3.2.1 Eixo da Formação Profissional................................................................. 55

3.2.1.1 A lacuna na formação.............................................................................. 56

3.2.2 Eixo dos Desafios e Possibilidades para o Cuidado Espiritual................... 60

3.2.2.1 Os fatores que influenciam a (des)integralidade do cuidado.......................... $\quad 60$

3.2.2.2 Os fatores que favorecem o atendimento das necessidades espirituais do paciente.

3.3 PERFIL DOS PACIENTES ................................................................

3.4 VIVÊNCIA DOS PACINTES ACERCA DA DIMENSÃO ESPIRITUAL E DOS CUIDADOS DE ENFERMAGEM................................................... 76

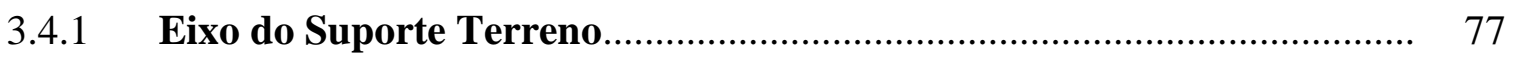

3.4.1.1 A Travessia Pessoal............................................................................. 78

3.4.1.2 A Travessia com a Família........................................................................ 79 
3.4.1.3 Outros Ajudantes na Travessia........................................................... 80

Eixo do Suporte Divino.................................................................. 84

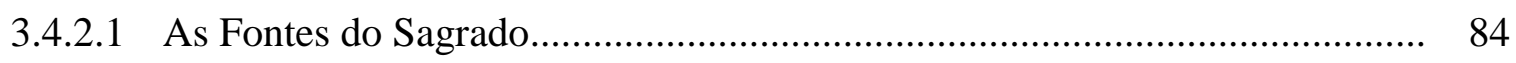

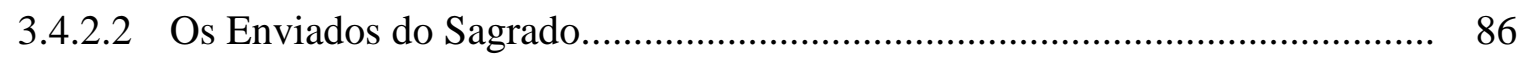

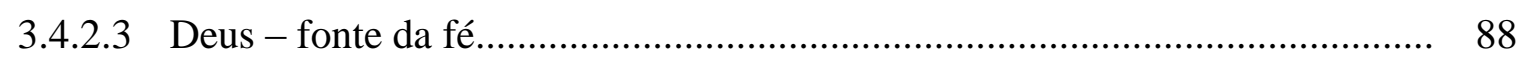

$4 \quad$ CONCLUSÃO

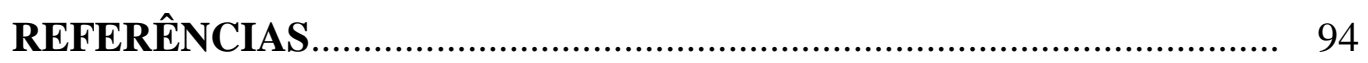

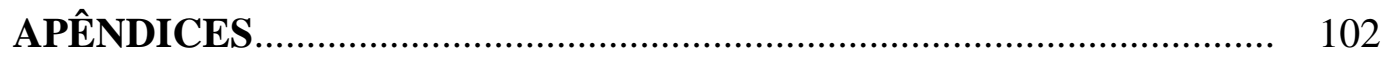




\section{APRESENTAÇÃO}

Meu interesse por questões espirituais vem desde criança. Nascido em uma família religiosa, a busca pela religiosidade/espiritualidade sempre esteve presente na minha vida.

Durante minha graduação em enfermagem, na Universidade de Brasília, busquei conhecer e aprender sobre como a espiritualidade poderia influenciar nos meus cuidados de enfermagem. Em meus estágios curriculares, percebia que muitos dos pacientes internados nos hospitais por onde passei apresentavam necessidades religiosas/espirituais afloradas. Apoiavam-se bastante nessas necessidades para enfrentar as adversidades da vida.

Após viver alguns anos nos Estados Unidos (2006-2009), tive a oportunidade de conhecer outros profissionais da área de saúde e fazer cursos que foram extremamente importantes para o meu crescimento pessoal e profissional; conheci e conversei com enfermeiros de diversas partes do mundo e muitos me mostraram uma enfermagem que se preocupava, também, com as questões espirituais dos seus pacientes. Isso me instigou bastante.

Ao retornar ao Brasil, continuei a trilhar meus caminhos na enfermagem. E um deles foi a docência universitária. Lecionei em três diferentes regiões do país: Centro-Oeste (Brasília), Sudeste (Minas Gerais) e Nordeste (Aracaju). Em todas elas, os pacientes internados demonstravam necessidades espirituais bem afloradas no processo de adoecimento e internação.

Em 2013, em Aracaju, em uma das minhas caminhadas pela orla de Atalaia, conheci uma feira de cultura sergipana. Nessa feira me deparei com um estande que vendia livros espíritas. E o título de um desses livros me chamou atenção: Espiritualidade no Cuidado com o Paciente: por quê, quando, como, o quê. Neste momento a curiosidade foi maior: comprei. Ao chegar a minha casa, pensei que o livro fosse de temática espírita ou de cunho religioso. Porém, para a minha surpresa, era um livro que apresentava diversas pesquisas científicas realizadas sobre a influência da espiritualidade na saúde. O interesse foi tanto que li suas 140 páginas em menos de três horas.

As pesquisas contidas no livro evidenciavam que a espiritualidade auxilia as questões relacionadas à saúde tanto física quanto mental e à qualidade de vida; demonstravam resultados benéficos do envolvimento religioso em relação à dor, debilidade física, doenças do coração, pressão sanguínea, dentre outras; demostravam que pessoas que apresentavam envolvimento religioso tinham menor probabilidade de usar/abusar de álcool, cigarros e 
drogas, menores taxas de suicídio e lidavam melhor com doenças graves como câncer e AIDS.

Chamou-me tanta atenção que resolvi compartilhar sobre a leitura desse livro nas minhas redes sociais, principalmente com meus alunos e colegas de profissão. Não muito depois recebo uma mensagem dizendo que o autor do livro, Harold Koenig, médico americano, era um dos maiores expoentes do assunto no mundo. Depois dessa notícia, resolvi comprar outros livros sobre o tema - Medicina e Saúde: o encontro da ciência e da espiritualidade; Handbook of Religion and Health - e ler artigos e revistas que versavam sobre saúde e espiritualidade.

Então comecei a me questionar: que tipo de formação eu tive na graduação para poder atender às necessidades espirituais do meu paciente? O que são realmente necessidades espirituais? Espiritualidade e religiosidade são a mesma coisa? Por que ciência e religião/espiritualidade se distanciaram tanto? Na minha vivência assistencial como enfermeiro, percebi que muitos pacientes buscam questões religiosas/espirituais para lidar com a doença. Por que nós, enfermeiros, não sabemos lidar com essa dimensão do ser humano? Por que a dimensão espiritual é "dispensável” dos cuidados de enfermagem, delegando essa assistência aos religiosos e religiosas que visitam os hospitais? Será que essa questão de integralidade do ser e a necessidade de o enfermeiro ver o seu paciente como um ser biopsicossocial e espiritual são uma utopia?

Frente a esses questionamentos, os resultados desta pesquisa podem auxiliar a enfermagem na busca de novo olhar sobre a dimensão espiritual e a inclusão de cuidados voltados a ela. Tenho certeza de que os pacientes poderão se beneficiar desses resultados. Mas tenho convicção de que eu fui o primeiro beneficiado.

Considerando-se, sobretudo, a necessidade de agregar conceitos de integralidade e espiritualidade no cuidado dos pacientes, novos estudos como este são necessários, em especial no Brasil. Estes estudos podem prover dados empíricos que possam ser utilizados no planejamento de intervenções de enfermagem espiritualmente embasados.

Nesse contexto, esta pesquisa buscou fundamentar, ancorar e ampliar as discussões sobre a necessidade de inclusão da dimensão espiritual no cuidado integral de saúde e de enfermagem. Além disso, por meio do discurso dos pacientes, ratificou-se a importância de se abordarem questões relacionadas à espiritualidade no contexto do cuidado de enfermagem e entender que espiritualidade vai além de oferecer assistência religiosa. 


\section{INTRODUÇÃO}

Estudos apontam que instituir a fé e a esperança como mecanismos de compreensão multidimensional do ser humano se torna imprescindível para a apreensão do processo de recuperação da saúde e enfrentamento saudável das doenças (Penha, 2012; Koenig, 2012; Moreira-Almeida; Stroppa, 2012). Dessa forma, aos poucos, o envolvimento religioso/espiritual vai se configurando como variável relevante na composição do indicador de saúde na busca da promoção de um cuidado integral (MOREIRA-ALMEIDA; STROPPA, 2012).

Paralelamente, na atualidade, os sistemas de saúde demandam por novas alternativas de cuidar, propondo uma inovação no paradigma do cuidado de enfermagem. Essa tendência vai ao encontro da teoria transpessoal de Jean Watson, uma vez que essa teoria se propõe a ir além dos modelos de cuidado tradicionais e estáticos da enfermagem. No modelo de cuidado proposto por Watson, o enfermeiro precisa estar aberto para as questões espirituais e dimensões existenciais do ser humano, compreendendo a si e aos outros como seres em evolução, com base na sacralidade do ser cuidado (GOMES et al., 2013).

Sendo assim, na perspectiva de Watson, o cuidado transpessoal traduz um ideal moral para a enfermagem, uma maneira de olhar para além da expressão física da doença. Busca encontrar as fontes mais profundas de cura interior, definida mais em termos espirituais do que na eliminação física da doença (WATSON, 2002a). A teoria de Watson não descarta a ciência convencional e as práticas de saúde modernas, mas configura-se por seu caráter complementar e potencializador dos processos de autorrecuperação, como facilitador da cura e da reconstituição interior (WATSON, 2002).

Desse modo, o cuidado transpessoal transcende a ideia simplificada de realização de uma tarefa ou cumprimento de protocolos, pois exige uma compreensão multidimensional dos aspectos da saúde, da doença e da relação entre quem cuida e quem é cuidado (BORGES, 2013).

Entretanto, observa-se que o cuidado de enfermagem praticado na atualidade ainda mantém a lógica cartesiana, reducionista, fragmentada, configurando-se em um modelo que privilegia a atenção da dimensão física em detrimento do cuidado das conexões que constituem a pessoa em toda a sua existência, incluindo-se a espiritual (BORGES, 2013).

Diante dessas considerações iniciais, entende-se ser importante e justificável proceder a um estudo que busque analisar a percepção dos enfermeiros sobre o papel da espiritualidade na integralidade do cuidado à luz da Teoria Transpessoal de Jean Watson. Espera-se 
contribuir para a melhoria da prática clínica e para a inclusão de cuidados de enfermagem que atendam às necessidades espirituais dos pacientes.

Dessa forma, este estudo teve como objetivo geral analisar as vivências de enfermeiros e pacientes acerca da abordagem da dimensão religiosa/espiritual nos cuidados de enfermagem com vistas a sua integralidade.

Pretende-se ainda atingir os seguintes objetivos específicos:

- apreender as vivências dos enfermeiros quanto à dimensão espiritual do cuidado sob o ponto de vista da integralidade do cuidado em saúde;

- identificar as estratégias utilizadas no manejo das necessidades espirituais dos pacientes;

- compreender a percepção dos pacientes sobre os cuidados de enfermagem em relação ao atendimento das suas necessidades espirituais.

Embora não conste do objetivo geral do estudo, optou-se também por identificar as necessidades espirituais dos pacientes nos cuidados em saúde. Espera-se que o levantamento dessas necessidades possa subsidiar de forma mais precisa os cuidados prestados pela equipe de enfermagem.

O presente estudo está estruturado em quatro partes, organizando-se da seguinte forma:

- Parte I - O Referencial Teórico

- A Integralidade e Suas Polissemias: busca discutir as diversas abordagens que o termo integralidade assume nos cuidados em saúde e define a abordagem adotada neste estudo;

- A Espiritualidade e a Integralidade no Cuidado em Saúde: objetiva o esclarecimento das dimensões do ser humano e a importância da dimensão espiritual no cuidado em saúde; a distinção entre espiritualidade e religiosidade; a compreensão da dimensão espiritual na perspectiva da integralidade e dos cuidados de saúde e de enfermagem; discute sobre algumas questões que devem permear a formação do enfermeiro para o cuidado integral;

- A Teoria do Cuidado Transpessoal: apresenta a teoria proposta por Jean Watson, suas fontes teóricas, seus postulados, o marco filosófico e conceitual da teoria; a definição operacional dos principais conceitos; o poder do campo energético no cuidado transpessoal; os Caritative 
Factors/Clinical Caritas Process e; a integralidade nos cuidados de enfermagem na visão transpessoal de Jean Watson.

- Parte II - Método: expõe a opção metodológica adotada, a fim de alcançar os objetivos do estudo.

- Parte III - Resultados e Discussão: explicam, de forma detalhada, os resultados obtidos, explicitando a visão dos enfermeiros e pacientes sobre as necessidades acerca da dimensão espiritual das mesmas.

- Parte IV - Conclusão: apresenta as respostas aos objetivos propostos nesta pesquisa e reflexões frente aos cuidados de enfermagem voltados à dimensão espiritual; analisa a expressão das necessidades espirituais dos pacientes, bem como sugere estratégias para que os cuidados espirituais sejam incluídos na assistência de enfermagem. 


\section{REFERENCIAL TEÓRICO}

\subsection{A INTEGRALIDADE E SUAS POLISSEMIAS}

A integralidade tem sido um tema atual e recorrente em pesquisas científicas no âmbito da saúde. Contudo, devido ao seu caráter polissêmico que inclui, segundo Teixeira (2003), diferentes sentidos, abordagens e usos, faz-se necessário explicitar alguns entendimentos do que vem a ser integralidade. Apesar dessa polissemia de conceitos, o termo integralidade possui um núcleo semântico bem claro e preciso que significa estar, todo, inteiro, completo; tornar-se inteiro, completar, inteirar, integralizar (FERREIRA, 1988).

E pensando no contexto da saúde, a integralidade pode ser discutida sob dois diferentes aspectos. O primeiro aspecto diz respeito ao conceito de integralidade como um princípio articulador do Sistema Único de Saúde (SUS) brasileiro que permeia o atendimento à população. Na atual Constituição Brasileira, o Estado deve garantir o acesso universal e igualitário aos serviços de saúde para sua promoção, proteção e recuperação. Nesse sentido, a integralidade aparece como um dos princípios do SUS que busca um atendimento integral, com prioridade para as atividades preventivas, sem prejuízo dos serviços assistenciais (MATTOS, 2004).

Esse atendimento integral busca incluir políticas e ações de saúde capazes de atender as demandas e as necessidades do usuário do sistema de saúde referentes ao acesso à rede de serviços. Nessa perspectiva, a integralidade é um conjunto articulado e contínuo de ações e serviços preventivos, curativos, individuais e coletivos nos diferentes níveis de complexidade do sistema, caracterizando-se como um princípio articulador do Sistema Único de Saúde (FRACOLLI et al., 2011).

Um segundo aspecto sobre o termo integralidade relaciona-se com um movimento que ficou conhecido nos Estados Unidos como medicina integral. Trata-se de uma crítica ao atendimento cada vez mais fragmentado e reducionista do ser humano por parte da equipe médica, que tem ressaltado exclusivamente a dimensão biológica, em detrimento das considerações psicológicas, culturais, sociais e espirituais do paciente. Esse movimento da medicina integral critica o sistema atual da saúde que privilegia as especialidades médicas que tendem a recortar analiticamente seus pacientes, tão-somente para os aspectos ligados ao funcionamento do sistema ou aparelho no qual os médicos se especializaram (MATTOS \&PINHEIRO, 2009). 
Assim, a medicina integral discute a integralidade como uma visão holística do ser humano. Isso significa compreender o indivíduo como um todo, isto é, considerando as dimensões de seu corpo físico, intelecto, sentimento e espírito; todas essas dimensões constituem a totalidade indivisível do ser humano. Como se pode perceber, essa abordagem integral busca anular a visão de um ser humano fragmentado, visto como partes distintas, num esforço para contemplar na prática do cuidado em saúde os seus aspectos: biológico, psicológico, social e espiritual (LINARDI; CASTRO, CRUZ, 2011).

Nessa linha argumentativa, Morin (2002) refere que um olhar sistêmico, no contexto da integralidade, é essencial para a compreensão do ser humano, da sua saúde e da sociedade. Para o autor, é impossível conhecer o todo sem conhecer as partes, e conhecer as partes sem conhecer o todo. Portanto, ao se discutir o termo integralidade exprimem-se conceitos como unidade, multiplicidade, totalidade, diversidade, organização e complexidade do cuidado (MORIN, 2002).

Complementando a visão de Morin, Gelbcke et al. (2011), ao tratar sobre o tema no âmbito da ciências sociais, humanas e, sobretudo, na área da saúde, referem que não se pode pensar no ser humano de maneira individualista e objetiva; é preciso olhar esse Ser humano de maneira completa, levando-se em conta suas emoções, sentimentos, paixões e sensações, como um ser subjetivo, embora tenha manifestações objetivas.

Santos et al. (2012), por sua vez, acrescentam outros aspectos importantes para a discussão e o entendimento do termo integralidade: para os autores, o ser humano integral é composto por matéria, alma e espírito. Nessa perspectiva, cuidar do ser humano em sua integralidade é atender seus sentimentos, emoções e desejos, progredindo para um patamar além das necessidades fisiológicas (SANTOS et al., 2012).

Assim, frente à polissemia do termo integralidade, é nesse último sentido que este estudo buscará compreender a integralidade do ser humano e dos cuidados de enfermagem. Considera-se que a qualificação do cuidado em saúde e enfermagem deve atender as necessidades manifestadas pelo ser humano em todas as suas dimensões, avançando para além do olhar fragmentado e reducionista do cuidado biomédico. 


\subsection{INTEGRALIDADE NO CUIDADO EM SAÚDE}

\subsubsection{As dimensões do ser humano e a importância da dimensão espiritual no cuidado em saúde}

Para compreender a integralidade do cuidado em saúde, faz-se necessária uma breve apresentação das dimensões que compõem o ser humano. De acordo com Röhr (2011), observa-se, num primeiro olhar, cinco dimensões básicas do ser humano: a primeira, a dimensão física, inclui a corporalidade físico-biológica. A segunda é a sensorial, que representa as sensações físicas, calor-frio, dor-prazer físico, doce-amargo, ou seja, a percepção advinda dos cinco sentidos: tato, visão, audição, olfato e paladar. A terceira referese à dimensão emocional, que abrange a psique, os estados emocionais como o medo, a insegurança, a euforia, a apatia, a tristeza, a melancolia, a impaciência, a solidão, a saudade, a indecisão, o pessimismo, dentre outras. A quarta dimensão, a mental, inclui o raciocínio lógico, tais como a lógica e a matemática, a capacidade de reflexão e questões que envolvem a recordação, a memória, a imaginação, a fantasia, a compreensão, a criação de ideias e a intuição. E a quinta dimensão, a espiritual, abrange a experiência que o ser humano teve durante a vida por meio das outras quatro dimensões e abrange também os valores éticos, religiosos e filosóficos. Assim, a dimensão espiritual do ser humano tem a principal função de guiar e dar sentido à vida (RÖHR, 2011).

Levando em conta a importância da dimensão espiritual do ser humano, a Organização Mundial de Saúde (OMS), em 1995, incluiu esse aspecto no conceito multidimensional de saúde. Logo, na perspectiva do cuidado integral, o bem-estar espiritual deve ser considerado nos cuidados em saúde, juntamente com as dimensões físicas, psíquicas e sociais do ser

humano. Como resultante da inserção da dimensão espiritual no conceito de saúde, a definição de saúde da OMS é um estado dinâmico de completo bem-estar físico, mental, espiritual e social, e não meramente a ausência de doença ou enfermidade (OMS, 1995).

Ao se incluir a dimensão espiritual no conceito de saúde, percebe-se a importância da dimensão religiosa/espiritual, em especial na área da saúde, pois muitos pacientes são religiosos, e crenças religiosas os ajudam a lidar com muitos aspectos de vida; crenças religiosas influenciam na saúde, nas decisões médicas e nos cuidados de enfermagem, especialmente quando os pacientes estão seriamente doentes; atividades e crenças religiosas estão relacionadas à melhor saúde e qualidade de vida e muitos pacientes gostariam que os 
profissionais de saúde abordassem essa dimensão espiritual e comentassem sobre ela durante a consulta e o tratamento (KOENIG, 2005).

Sabe-se que a presença de emoções e do diálogo possibilitam manifestações de afeto, altruísmo, solidariedade, respeito e confiança no outro e estabelecem conexões importantes em busca da espiritualidade do ser e, consequentemente, o respeito à integralidade do ser humano (Coscrato, 2013). Desta maneira, são claras as demandas que justificam a discussão da dimensão espiritual no cuidado em saúde.

Estudos têm demonstrado que a mobilização da dimensão espiritual nos cuidados em saúde pode promover alívio da angústia e ansiedade, melhorando o estado de saúde emocional e física do ser humano (Pedrão; Berezin, 2010). Como exemplo dessas pesquisas na área da saúde e espiritualidade, Koenig (2001) investigou 225 estudos que evidenciaram resultados benéficos do envolvimento religioso/espiritual em relação à dor, debilidade física, doenças do coração, pressão sanguínea, infarto, funções imunes, neuroendócrinas, doenças infecciosas, câncer e mortalidade (KOENIG, 2001).

$\mathrm{O}$ autor comprovou que pessoas que apresentam envolvimento religioso têm menor probabilidade de usar/abusar de álcool, cigarros e drogas, ou de apresentar comportamento de risco, como atividades sexuais extramaritais, delinquência e crime. Observou, também, a influência da religiosidade nos adolescentes, sendo a sua falta relacionada negativamente ao suicídio e atividade sexual/gravidez prematuras (KOENIG, 2001).

Outras pesquisas também demonstraram que a espiritualidade/religiosidade tem relação direta com a melhora da qualidade de vida $(\mathrm{QV})$ do indivíduo, família e comunidade. Os estudos evidenciaram que as organizações religiosas contribuem para a integração da comunidade, consequentemente aumentando a QV; além disso, os princípios da religião podem atrair pessoas com disposição para a felicidade e podem justificar um propósito na vida que promova bem-estar (FERRIS, 2002).

No âmbito da enfermagem, um dos primeiros trabalhos de revisão de literatura sobre o significado de espiritualidade foi desenvolvido por Dyson (1997) com o objetivo de identificar como a Espiritualidade era tratada na literatura corrente, bem como estabelecer quais seriam os possíveis entendimentos sobre necessidades espirituais.

O autor identificou a espiritualidade como uma aspiração para o bom relacionamento com o Sagrado, com o outro e consigo mesmo, seguido de um sentido para a vida. Verificou que a esperança é uma necessidade espiritual dos pacientes pesquisados; outro dado foi a necessidade da escuta ativa e da sensibilidade aguçada dos enfermeiros para que eles pudessem acessar a dimensão espiritual de seus pacientes (PENHA, 2012). 
Um aspecto importante no estudo de Dyson (1997) apontou para a relação direta do termo espiritualidade com a ideia de religiosidade, pois, na época, os escassos estudos que tratavam do tema da espiritualidade propriamente dita procuravam acessar a influência religiosa dos pacientes nas questões de saúde-doença (PENHA, 2012).

Nessa perspectiva, ao acessar a dimensão espiritual nos cuidados em saúde, questões importantes são levadas em consideração como o Sentido (significado ontológico para a vida, advindo das mais diversas experiências), os Valores (crenças e padrões culturalmente aceitos, vistos por meio de comportamentos comuns para determinados povos), a Transcendência (experiências que permeiam o campo da subjetividade), a Conectividade (relacionamento com o Sagrado, com os outros, com a natureza e consigo mesmo), e por fim o Tornar-se que é a busca do Ser Humano por um desdobramento da vida e a busca por um sentido pleno para a existência (ROSS, 2006).

\subsubsection{Distinção entre Espiritualidade e Religiosidade}

O uso dos termos espiritualidade, destacado de religião, e religiosidade é bastante recente e teria ocorrido em torno das décadas de 1960 e 1970 (MOREIRA-ALMEIDA; STROPPA, 2012).

A dificuldade existente com relação aos conceitos pode se constituir numa deficiência séria no campo de estudos da religiosidade/e ou espiritualidade e saúde, pois, se os termos não forem utilizados apropriadamente e consistentemente, esse campo de pesquisa enfrentará sérios problemas quanto a sua validade e coerência (HUFFORD, 2005).

Religião é entendida como uma prática institucionalizada de um sistema de crenças, rituais e símbolos, compartilhado por uma comunidade. Espiritualidade, por sua vez, trata-se de uma busca pessoal por significado e sentido maior no existir e sua relação com o sagrado e o transcendente, podendo ou não estar vinculada a uma religião formalizada ou uma designação religiosa (DAL-FARRA; GEREMIA, 2010).

Observa-se que o conceito abordado por Dal-Farra \& Geremia (2010) está em consonância com os conceitos defendidos por Harold Koenig, maior expoente na área da pesquisa em saúde e espiritualidade, atualmente. Para Koenig (2001), a religiosidade pode ser conceituada como um conjunto de crenças e práticas observadas por uma comunidade, apoiadas por rituais que reconhecem, idolatram e comunicam-se com o Sagrado ou aproximam-se dele. Este Sagrado refere-se a Deus (em culturas ocidentais) ou à Verdade Absoluta, à Realidade ou ao Nirvana (em culturas orientais), enquanto a espiritualidade 
retrata a multidimensionalidade da experiência humana. Assim, para Koenig, a espiritualidade possui três aspectos: o cognitivo, o experiencial e o comportamental (KOENIG, 2001).

$\mathrm{O}$ aspecto cognitivo ou filosófico da espiritualidade inclui a busca de um significado, de um propósito e de uma verdade na vida, bem como as crenças e os valores de acordo com os quais uma pessoa vive. Os aspectos experienciais e emocionais envolvem sentimentos de esperança, amor, conexão, paz interior, conforto e suporte. Eles se refletem na qualidade de recursos internos de um indivíduo, na capacidade de dar e receber amor espiritual e nos tipos de relações e conexões que existem consigo mesmo, com a comunidade, como o meio ambiente, com a natureza e com o transcendental (KOENIG, 2001).

O aspecto comportamental da espiritualidade envolve o modo como a pessoa manifesta externamente as crenças espirituais individuais e o estado espiritual interno. Muitas pessoas encontram a espiritualidade por meio da religião ou de um relacionamento pessoal com o Divino. Porém, outros podem encontrá-la por meio de uma conexão com a natureza, com a música e as artes, por meio de um conjunto de valores e princípios ou por uma busca da verdade científica (Koenig, 2001). Portanto, uma pessoa pode ser espiritualizada sem necessariamente ser religiosa.

Outra maneira que se pode distinguir a religiosidade da espiritualidade é a proposta por Wilkinson \& Van Leuven (2010). Eles associam os conceitos de religião e espiritualidade aos de mapa e viagem, sendo a religião o "mapa" e a espiritualidade "a viagem". Para se chegar a um determinado lugar, muitas pessoas usam um mapa para guiá-las. Essa alusão entre mapa e religião diz respeito às crenças das pessoas e aos valores essenciais da vida. Assim, rituais, símbolos, sacramentos e escrituras sagradas associados a religiões servem como um mapa, um suporte e proporcionam maneiras distintas para transcender o físico e acessar o Sagrado, o Divino (WILKINSON \& VAN LEUVEN, 2010).

Seguindo essa lógica, se a religião serve como um mapa, a espiritualidade é vista como a viagem que a pessoa precisa seguir - a viagem do dia a dia. Como uma viagem, a espiritualidade se constrói ao longo do tempo e envolve o acúmulo de experiências de vida combinadas com a compreensão obtida. Isto é, a espiritualidade busca encontrar um significado, um valor e um objetivo na vida. (WILKINSON \& VAN LEUVEN, 2010).

O Quadro 1 ilustra a distinção de religião e espiritualidade, conforme Wilkinson \& Van Leuven. 
Quadro 1 - Distinção entre Religião e Espiritualidade

\begin{tabular}{|c|c|}
\hline Religião (O Mapa) & Espiritualidade (A Viagem) \\
\hline $\begin{array}{l}\text { Define crenças, valores e códigos de } \\
\text { conduta ética. }\end{array}$ & Refere-se à viagem através da vida. \\
\hline $\begin{array}{l}\text { Tradição ou sistema de adoração que } \\
\text { fornece rituais, respostas, normas, ligação } \\
\text { com o Sagrado, o Divino. }\end{array}$ & $\begin{array}{l}\text { Busca pessoal para definir significado, } \\
\text { plenitude e satisfação na vida. }\end{array}$ \\
\hline $\begin{array}{l}\text { Define em que se deve crer; como as } \\
\text { crenças afetam a vida, a autoimagem e a } \\
\text { identidade da pessoa. }\end{array}$ & $\begin{array}{l}\text { Desejo de viver; autoconfiança; relação } \\
\text { dinâmica com aquilo que transcende. } \\
\text { Questões: fé, esperança amor. }\end{array}$ \\
\hline $\begin{array}{l}\text { Questões importantes como: fé, confiança, } \\
\text { natureza do bem e do mal, o significado do } \\
\text { sofrimento, julgamento ou iluminação. }\end{array}$ & $\begin{array}{l}\text { Capacidade de conhecer e ser conhecido; } \\
\text { conectividade consigo, com outros, com a } \\
\text { natureza e com um poder superior. }\end{array}$ \\
\hline & $\begin{array}{l}\text { Processo constante de absorver a "verdade" e } \\
\text { depois acrescentar revelação individual para } \\
\text { chegar a uma maneira de perceber e agir no } \\
\text { mundo. }\end{array}$ \\
\hline
\end{tabular}

Fonte: Adaptado de Wilkinson \& Van Leuven (2010).

\subsubsection{A dimensão espiritual dos cuidados de saúde e de enfermagem}

Desde que surgiu a vida, os cuidados existem, já que é necessário "cuidar da vida" para que ela se perpetue. Porém, é necessário reconciliar, ligar, ou seja, relacionar o que diz respeito ao corpo e ao espírito; unir sentimento, espiritualidade e racionalidade científica aos cuidados de enfermagem ao ser humano. O desafio da enfermagem é unir esse cuidado que tem sido cada vez mais fragmentado (COLLIÈRE, 2003).

Quando uma pessoa vivencia situações de crise, que fogem ao seu controle, ou mesmo encontra dificuldade de contorná-las, ela tende a procurar recursos, muitas vezes relacionados à fé e à espiritualidade. Essa busca pela dimensão espiritual a mantém o mais conectada possível com o mundo que a rodeia trazendo tranquilidade, esperança, conforto e melhor perspectiva de vida (Souza, Maftum, Bais, 2008; Carvalho, 2008). Essa crise pode ser 
compreendida como um estado psicológico, em que o fator desencadeante é o desequilíbrio entre a percepção da dificuldade, a importância do problema e os recursos disponíveis para a solução (SOUZA, MAFTUM, BAIS, 2008).

E para cuidar de uma pessoa em crise exige-se um olhar integral para a situação enfrentada; e para isso deve-se incluir a dimensão espiritual. Vale destacar que muitos enfermeiros têm se preocupado com a integralidade do cuidado de enfermagem, valorizando tanto as necessidades físicas, quanto emocionais e espirituais dos doentes. Florence Nightingale, precursora da enfermagem moderna, reitera a interligação entre a pessoa e o ambiente, entre a pessoa e a natureza, entre os mundos internos e externos, entre o privado e o público, entre o físico e o espiritual. Alguns dos modos de interpretar o conhecimento de Nightingale incluíam uma visão e uma imagem de integralidade, de beleza e de harmonia de vida (WATSON, 2002).

Nightingale já ressaltava a necessidade de incluir a espiritualidade nos cuidados em saúde e afirmou que a profissão de enfermagem deve estar baseada em valores que respeitem a singularidade da mente-corpo-espírito do ser humano. Nesse aspecto, Nightingale se preocupava em integrar as práticas básicas do cuidar e a arte da enfermagem; preocupava-se com as questões humanísticas, altruísticas, espirituais, científicas e existenciais do ser humano (WATSON, 2002a).

Desde o século XIX, com Florence Nightingale, a educação, a pesquisa e a prática de enfermagem compreendiam que a espiritualidade do ser humano permeia os cenários de cuidado e que deve ser resgatada na enfermagem contemporânea (Watson, 2002a). Porém, na metade do século XX, com o desenvolvimento do método científico tradicional, a enfermagem começou a se distanciar da dimensão espiritual e sua inter-relação com o cuidado do paciente. Recentemente a enfermagem - bem como a comunidade geral em saúde - voltou a discutir a dimensão espiritual como parte vital da sua identidade; reconheceu seu poder de influenciar a saúde (WILKINSON \& LEUVEN, 2010).

Nessa perspectiva, McSherry \& Cash (2003) referem que a retomada da espiritualidade e o grande interesse por ela, por parte dos enfermeiros, estão relacionados, principalmente, à noção de integralidade do cuidado que abrange todas as dimensões do ser humano. Atualmente, pesquisadores no âmbito da enfermagem buscam novas abordagens que atendam não somente as competências tecnológicas, mas também as competências ontológicas, que são essenciais à maturidade e à sobrevivência da profissão. 
E, para acessar a dimensão espiritual dos pacientes, diferentes autores buscaram compreender a espiritualidade e sua inclusão nos cuidados integrais do ser humano. Shelly e Fish (1988), Dossey (1998), Balzer-Riley (2004) e Taylor; Lillis e LeMone (2008) ofereceram subsídios importantes para que os enfermeiros possam acessar a dimensão religiosa/espiritual de seus pacientes conforme demonstrado no Quadro 2.

Quadro 2 - Fatores para investigação, perguntas e abordagens da dimensão espiritual.

\begin{tabular}{|c|c|}
\hline Fatores a Investigar & Perguntas e Abordagens \\
\hline Dor espiritual & $\begin{array}{l}\text { Você já se sentiu ferido ou com dor associada às crenças } \\
\text { espirituais ou religiosas que sustenta? }\end{array}$ \\
\hline Alienação espiritual & Você se sente frequentemente distante de Deus? \\
\hline Ansiedade espiritual & $\begin{array}{l}\text { Você está com medo de que Deus não esteja presente quando } \\
\text { você precisar? }\end{array}$ \\
\hline Culpa espiritual & Você já fez algo que poderia levar Deus a se zangar com você? \\
\hline Raiva espiritual & $\begin{array}{l}\text { Você está com raiva de Deus por permitir que você adoeça? } \\
\text { Acredita que Deus é injusto com você? }\end{array}$ \\
\hline Perda espiritual & Você já se sentiu como se tivesse perdido o amor de Deus? \\
\hline Desespero espiritual & $\begin{array}{l}\text { Você alguma vez sentiu que não há esperança de ter o amor de } \\
\text { Deus? Que Ele não o ama mais? }\end{array}$ \\
\hline Crenças espirituais & $\begin{array}{l}\text { Existem crenças religiosas ou espirituais particulares } \\
\text { importantes para você? }\end{array}$ \\
\hline Práticas espirituais & $\begin{array}{l}\text { Descreva suas práticas espirituais habituais e qualquer coisa que } \\
\text { interfira em sua capacidade de executá-las. Posso ajudar de } \\
\text { alguma maneira para assegurar os préstimos necessários para } \\
\text { essas práticas (Bíblia, cristais, rosários, ícones)? }\end{array}$ \\
\hline $\begin{array}{l}\text { Relação entre } \text { crenças } \\
\text { espirituais e } \quad \text { a vida } \\
\text { diária }\end{array}$ & $\begin{array}{l}\text { Descreva os meios pelos quais suas crenças espirituais afetam } \\
\text { sua vida diária (dieta, higiene, relacionamentos). Você } \\
\text { considera essa influência saudável ou destrutiva? }\end{array}$ \\
\hline
\end{tabular}




\begin{tabular}{|c|c|}
\hline Fatores a Investigar & Perguntas e Abordagens \\
\hline $\begin{array}{l}\text { Deficiência espiritual ou } \\
\text { angústia }\end{array}$ & $\begin{array}{l}\text { Suas crenças espirituais atualmente lhe causam alguma } \\
\text { angústia? }\end{array}$ \\
\hline Necessidades espirituais & $\begin{array}{l}\text { De que modo podemos ajudá-lo a satisfazer suas necessidades } \\
\text { espirituais? }\end{array}$ \\
\hline $\begin{array}{l}\text { Necessidade de sentido e } \\
\text { propósito }\end{array}$ & $\begin{array}{l}\text { De que modo suas crenças religiosas ajudam ou atrapalham a } \\
\text { possibilidade de entender sua situação atual e a encará-la com } \\
\text { paz e coragem? }\end{array}$ \\
\hline $\begin{array}{l}\text { Necessidade de amor e } \\
\text { relacionamentos }\end{array}$ & $\begin{array}{l}\text { De que modo suas crenças religiosas o ajudam ou atrapalham na } \\
\text { satisfação de sua necessidade de amar e ser amado? }\end{array}$ \\
\hline Necessidade de perdão & $\begin{array}{l}\text { De que modo suas crenças religiosas o ajudam ou atrapalham a } \\
\text { se sentir em paz? }\end{array}$ \\
\hline $\begin{array}{l}\text { Observações } \\
\text { comportamentais } \\
\text { significativas }\end{array}$ & $\begin{array}{l}\text { Estar alerta a mudanças súbitas nas práticas espirituais, } \\
\text { mudanças de humor, interesse súbito em assuntos espirituais e } \\
\text { distúrbios do sono - todos podem apontar para necessidades } \\
\text { espirituais não resolvidas. }\end{array}$ \\
\hline Significado e Propósito & $\begin{array}{l}\text { O que é que dá sentido a sua vida? Está motivado para ficar } \\
\text { bom? Qual é a coisa mais importante ou poderosa na sua vida? }\end{array}$ \\
\hline Força interior & $\begin{array}{l}\text { O que você pode fazer para se sentir vivo e grande de espírito? } \\
\text { Quais são suas forças pessoais? Que objetivos de vida propôs a } \\
\text { si mesmo? De que forma a doença influenciou o seu destino? }\end{array}$ \\
\hline $\begin{array}{l}\text { Autoconceito positivo, } \\
\text { autoestima, sentimento } \\
\text { de pertencimento }\end{array}$ & $\begin{array}{l}\text { Como é que se sente em relação a si neste momento? O que é } \\
\text { que faz para se sentir bem espiritualmente? }\end{array}$ \\
\hline $\begin{array}{l}\text { Capacidade de entrega à } \\
\text { família, amigos, grupos } \\
\text { sociais e de perdoar aos } \\
\text { outros }\end{array}$ & $\begin{array}{l}\text { Quem são as pessoas mais importantes na sua vida?Pode pedir } \\
\text { ajuda às pessoas quando precisa? Consegue partilhar os seus } \\
\text { sentimentos com outros? Que ações carinhosas que você já fez e } \\
\text { que já fizeram para você? Consegue perdoar aos outros? Cont. }\end{array}$ \\
\hline
\end{tabular}




\section{Fatores a Investigar}

Sentido em atividades de Participa de atividades religiosas? Acredita no poder da oração? devoção religiosa e de Pratica atividades de relaxamento, meditação, visualização, descobrir uma ligação rezas? Como são suas preces? com o Divino

Sentimento de ligação De que forma seu meio interage com o seu bem-estar? Está com a vida, natureza; preocupado com a sobrevivência do planeta? consciência dos efeitos

do meio na vida e no bem-estar

Fonte: Adaptação Taylor; Lillis; LeMone (2008); Balzer-Riley, 2004); Dossey (1998).

Observa-se que para identificar e explorar a dimensão espiritual depende, fundamentalmente, da sensibilidade e da emoção do enfermeiro para o processamento e interpretação do conteúdo observado, para então emergir a resposta comunicacional, que é o ato de cuidar (Penha, 2012). Esse ato de cuidar tornar-se-á contextualizado, integral; reconhecer-se-á e valorizar-se-á o outro, por meio do exercício de sensibilidade, escuta, acolhimento, crítica e criatividade por parte dos sujeitos envolvidos no cuidado. Trata-se de um novo paradigma do cuidado de enfermagem (COSCRATO, 2013).

\subsection{A TEORIA DO CUIDADO TRANSPESSOAL}

\subsubsection{Sobre Jean Watson}

Margareth Jean Harman Watson, norte-americana do estado de Virgínia, obteve o grau de bacharel em Enfermagem (1964) pela Lewis Gale School of Nursing, o título de Mestre em Enfermagem Psiquiátrica (1966) e Doutora e Pós-Doutora em Psicologia da Educação (1973) pela Universidade do Colorado. Desde então está vinculada à Escola de Enfermagem dessa universidade, na cidade de Denver, Colorado, Estados Unidos (PENHA, 2012).

Interessada pela cultura espiritualista indiana, Watson ressignificou muitos dos seus conceitos quando em uma visita a um hospital na cidade de Mumbai, Índia, observou um 
quadro na parede de um dos quartos de uma criança que dizia: A vida não é um problema para ser resolvido, mas um mistério para ser vivido (PENHA, 2012).

Para Watson (2002), essa experiência foi a inspiração para desenvolver uma nova forma de pensar e fazer Enfermagem. Para ela o processo de Cuidar envolve um íntimo relacionamento entre dois Seres, distintos de personalidade, mas iguais em essência e que independe da cura para ser sustentado em si mesmo. Watson, por meio da estruturação da Teoria do Cuidado Transpessoal, buscou modificar as práticas e modelos de cuidado a partir do paradigma espiritualista nas relações interpessoais que são inerentes ao processo de Cuidar em Enfermagem (PENHA, 2012).

\subsubsection{Fontes Teóricas}

Para o desenvolvimento de sua teoria transpessoal do cuidado, Jean Watson inspirou-se no conhecimento tradicional de enfermagem, nas obras das teoristas Florence Nightingale, Virgínia Henderson, Green \& Krueter e Lydia Hall. Reconheceu as obras de Medeleine Leininger, Sally Gadow e Hildegard Peplau como sustentação para o seu trabalho. Em seus recentes trabalhos, Watson recorre aos pensamentos do psicólogo Abraham Maslow, dos filósofos Martin Heidegger e Erik Erickson, do médico Hans Selye, do filósofo e psicólogo Moritz Lazarus, do lógico e metafísico Alfred Whitehead, do teólogo e filósofo Teilhard de Chardin e do filósofo Jean-Paul Sartre. Watson faz referência à orientação filosófica e intelectual, à teoria feminista, à física quântica, às tradições do senso-comum além de aproximar-se profundamente das ciências, das humanidades e das artes liberais, fornecendo uma orientação fenomenológica, existencial e espiritual (TOMEY; ALLIGOOD, 2004)

As relações interpessoais e transpessoais de coerência, empatia e calor humano, defendidas na perspectiva do psicólogo Carl Rogers, também foram importantes para a consolidação dos construtos teóricos de Watson. Rogers acreditava que "através da compreensão" o doente viria a aceitar-se a si próprio, um passo inicial no sentido de um resultado positivo. Juntos, o terapeuta e o paciente compreendem o significado da experiência do doente. Assim, a relação terapeuta-doente é mais importante para o resultado do que a adesão aos métodos tradicionais de cura (TOMEY; ALLIGOOD, 2004). 


\subsubsection{Postulados}

Segundo Watson, a enfermagem está interessada em compreender a saúde, a doença e a experiência humanas. Dentro da filosofia e da ciência do cuidar, ela crê que a enfermagem diz respeito à promoção, recuperação da saúde e prevenção da doença (TOMEY; ALLIGOOD, 2004).

Para tanto, Watson descreve que o cuidar, como premissa básica da enfermagem, existiu em todas as sociedades. Uma atitude de cuidar transmite-se pela cultura da profissão como única forma de lidar com o seu ambiente. Porém, existe, muitas vezes, uma discrepância entre a teoria e a prática de enfermagem, ou entre aspectos científicos e artísticos do cuidar, em parte devido à disjunção entre valores científicos e valores humanos (WATSON, 2002).

Assim, Watson defende que: 1) a mente e as emoções de uma pessoa são janelas para a alma; 2) o corpo de uma pessoa está confinado ao tempo e ao espaço, mas a mente e a alma não estão confinadas ao universo físico; 3) o acesso ao corpo, à mente e à alma só é possível desde que a pessoa seja vista e tratada como um todo; 4) o espírito, o ser interior ou a alma de uma pessoa existe em e por si própria; 5) as pessoas precisam umas das outras de forma interessada e amorosa; 6) para se encontrarem soluções, é necessário encontrarem-se sentidos e; 7) a totalidade da experiência num dado momento constitui um campo de fenômenos (WATSON, 2002).

\subsubsection{Marco filosófico e conceitual da Teoria do Cuidado Transpessoal}

Watson (2002) propõe que o cuidado e o amor são "forças cósmicas" universais e misteriosas, que compreendem a energia psíquica primária e universal. Para isso, desenvolveu sua teoria sob a égide de seis pilares (pressupostos): 1) um pressuposto ontológico de unicidade, totalidade, unidade, relação e conexão; 2) um pressuposto epistemológico segundo o qual existem múltiplas formas de conhecer; 3) a diversidade de conhecimento assume tudo, e várias formas de evidência podem estar envolvidas; 4) um modelo de Ciência do Cuidado torna essas diversas perspectivas explícitas e diretas; 5) a integração moral-metafísica e ciência evoca o espírito; tal orientação não é apenas possível, mas também necessária para a ciência, humanidade, sociedade/civilização e mundo/planeta; 6) a emergência da Ciência do Cuidado, fundamentada sobre os novos pressupostos, torna explícita uma visão de mundo 
unitária, expandida, energética, com uma ética de atendimento humano relacional e uma ontologia como seu ponto inicial (WATSON, 2002).

Para Watson (2009), existe uma dimensão "sagrada" no Cuidado e que buscamos uma fonte espiritual quando estamos vulneráveis, suscetíveis, temerosos ou mesmo doentes. Assim, o enfermeiro, ao assumir a Ciência do Cuidado, deve compreender que: a) o Cuidado não pode ser assumido como verdadeiro e único; b) há envolvimento entre as Artes, as Ciências Humanas e as Ciências da Saúde na Ciência do Cuidado; c) o conhecimento envolve ética, intuição, experiências pessoais, empíricas, estéticas e espirituais e; d) o Cuidado existe em toda e qualquer sociedade, onde cada pessoa tem cuidado umas com as outras. As influências culturais são responsáveis pela transmissão da Relação do Cuidado, sendo que a cultura da Enfermagem, enquanto disciplina e profissão, tem papel científicossocial vital na preservação e avanço do cuidado humano (WATSON, 2009).

\subsubsection{Definição operacional dos principais conceitos}

A definição operacional é um procedimento que atribui um significado comunicável a um conceito por meio da especificação de como o conceito é aplicado dentro de um conjunto específico de circunstâncias; necessita ser específica, concreta, mensurável e útil para as pessoas envolvidas (McEWEN, WILLS, 2009; TOMEY, ALLIGOOD, 2004; SILVA, 2011).

Existem quatro metaparadigmas que norteiam a elaboração de uma teoria no campo da Ciência da Enfermagem: ser humano, ambiente, saúde e enfermagem. Watson (2002) acrescentou outros conceitos que fazem parte do entendimento da ciência do cuidado humano, como enfermeiro, doença, dimensão espiritual, harmonia/desarmonia, empenhamento, necessidades humanas, a ocasião real do atendimento, o cuidado transpessoal, o campo fenomenal, o eu, e o tempo. Nesse sentido Watson elaborou a definição operacional dos seus principais conceitos a seguir:

- Ser Humano - é uma pessoa valorizada em si mesma e para si mesma para ser cuidada, respeitada, nutrida, compreendida e auxiliada. O estado mental, emocional e o campo fenomenológico de uma pessoa podem variar de momento para momento, conforme os seus sentidos objetam - sons, cheiros, gostos, visão, memórias fortuitas, planos futuros; outros pensamentos misturam-se, e associam-se frequentemente como objetos dos sentidos e tornamse parte do campo fenomenológico;

- Saúde - mesmo conhecendo a definição da Organização Mundial da Saúde, Watson acredita na necessidade da inclusão de outros fatores, como alto nível de funcionamento geral 
físico, mental e social; nível geral de adaptação-manutenção do funcionamento diário; ausência da doença, ou presença de esforços que levam a sua ausência. Acredita que o atendimento de saúde deve ir além do diagnóstico de doença, do tratamento da enfermidade e da prescrição de drogas, mas o verdadeiro atendimento de saúde envolve também o estilo de vida da pessoa, as condições sociais e o ambiente em que vive;

- Ambiente/Sociedade - uma das variáveis que afeta a sociedade no mundo de hoje é o ambiente social. A sociedade proporciona valores que determinam como a pessoa deve comportar-se e quais as metas a serem perseguidas. As pessoas também têm uma necessidade intrínseca de pertencer, de ser parte de um grupo e da sociedade como um todo. Watson afirma que a atitude de cuidar não é transmitida de geração para geração por meio dos genes, mas transmitida pela cultura;

- Enfermagem - para Watson, Enfermagem é a ciência humana das pessoas e das experiências de saúde/doença que são mediadas por transações profissionais, pessoais, científicas, estéticas e éticas do atendimento humano. Caracterizada por cuidar como um imperativo ético e moral de relação transpessoal. Nesse contexto a pessoa deve ser vista em sua integralidade, como um todo, ou seja, seres com mente, emoções, corpo e espírito;

- Enfermeiro - é um coparticipante num processo em que o ideal do cuidar é a intersubjetividade. O enfermeiro não pode ignorar ou substituir os componentes morais, espirituais e metafísicos da natureza humana da enfermagem. O enfermeiro precisa ser cientista, teórico, clínico, humano e estar envolvido como um coparticipante ativo nas transações humanas do cuidar;

- Campo fenomenal (fenomenológico) - é a totalidade da experiência humana de estar no mundo. Alude à estrutura individual de referência que pode ser conhecida apenas por aquela pessoa. $\mathrm{O}$ conhecimento científico básico e o conhecimento humanístico são essenciais para a ciência e para a arte da Enfermagem. A análise fenomenológica de experiências humanas na saúde e na doença proverá aos enfermeiros dados necessários para entender a condição humana. O campo fenomenológico não é idêntico à consciência, mas incorpora a consciência juntamente com as percepções do $\mathrm{Eu}$ e dos outros; sentimentos, pensamentos, sensações físicas, crenças espirituais, desejos, objetivos, expectativas - tudo isto é baseado na história de vida de cada um, o momento presente e o futuro idealizado;

- Necessidades Humanas - as necessidades humanas consistem na necessidade em ser amado, cuidado, na necessidade de consideração positiva e na necessidade de ser aceito, compreendido e valorizado. Há também a necessidade humana de união, de transcender a vida individual de cada um e encontrar harmonia com a vida; 
- Cuidar Transpessoal - o cuidar transpessoal é científico, profissional, ético, estético e criativo. O contato entre duas pessoas (enfermeiro e o outro) permite entrar em contato com o mundo subjetivo das pessoas que o experienciam, por meio de rotas físicas, mentais, espirituais ou alguma combinação dessas.

Os dois indivíduos (enfermeiro e o outro) estão num processo de serem e de se tornarem. Ambos os indivíduos trazem consigo para a relação uma história de vida única e um campo fenomenológico, estando ambos influenciados e afetados pela natureza da transação, que, por sua vez, torna-se parte da história e da vida de cada pessoa.

O cuidado transpessoal é o relacionamento intersubjetivo do ser humano-para-serhumano, no qual o enfermeiro afeta e é afetado pelo outro. Ambos estão totalmente presentes no momento e sentem a união com o outro; compartilham o campo fenomenal que se torna parte da história de vida dos dois; o campo fenomenal é a totalidade da experiência humana de estar no mundo, refere-se à estrutura individual de referência que pode ser conhecida apenas por aquela pessoa.

No cuidar transpessoal, o enfermeiro pode entrar na experiência da outra pessoa, e o outro pode entrar na experiência do enfermeiro. O ideal do cuidar transpessoal é um ideal de intersubjetividade, no qual ambas as pessoas estão envolvidas. Isto significa que os valores e perspectivas do enfermeiro, embora não decisivas, são potencialmente tão relevantes como a do paciente. Não permitir que a subjetividade do enfermeiro seja apreendida pelo usuário é, como efeito, não reconhecer a validade da subjetividade do usuário. A alternativa ao cuidar com intersubjetividade não é simplesmente a redução do doente a um objeto, mas a redução do enfermeiro a esse nível também;

- Dimensão espiritual - o mundo do espírito e da alma torna-se progressivamente mais importante à medida que uma pessoa cresce e amadurece como um indivíduo e à medida que a humanidade evolui coletivamente. A proeminência do aspecto espiritual de uma pessoa ou raça varia de indivíduo para indivíduo, de cultura para cultura e no íntimo dele próprio;

- Harmonia-Desarmonia - onde há desarmonia entre mente, corpo e alma ou entre uma pessoa e o mundo, há uma disjunção entre o eu como é percebido e a experiência atual de cada um, havendo também um sentimento de incongruência no íntimo da pessoa;

- Empenhamento - a pessoa possui um empenhamento básico: atualizar o verdadeiro Eu, desenvolvendo a essência espiritual do Eu. Quanto mais cada um de nós for capaz de experienciar o Eu verdadeiro, mais harmonia existirá no íntimo da mente, do corpo e da alma; existirá, então, um grau mais elevado de saúde. No início da vida, as pessoas estão mais 
atentas ao sentido de harmonia entre mente/emoções e corpo, mais ainda à medida que crescemos e permitimos que o lado existencial e espiritual do Eu se desenvolva;

- Um Evento ou Ocasião Real de Cuidar - envolve as ações do enfermeiro e do indivíduo. O momento do atendimento proporciona a ambos a oportunidade de decidir como será o relacionamento e o que fazer com o momento. As duas pessoas (enfermeiro e o outro) juntas, com as suas histórias de vida únicas e o campo fenomenológico numa transação de cuidar, abrangem um evento. Um evento, como uma ocasião real de cuidar, é um ponto focal no tempo e no espaço, no qual a experiência e a percepção estão a tomar lugar. Porém a ocasião real do cuidar tem um campo próprio, que é maior do que a própria ocasião. Deste modo, o processo pode ir além dele próprio, e ainda salientar-se de aspectos seus que se tornam parte da história de vida de cada pessoa, assim como parte de um padrão de vida mais amplo, mais profundo e mais complexo.

O momento da ocasião do cuidar torna-se parte da história de vida passada de ambas as pessoas (enfermeiro e o outro) e dá a ambas novas oportunidades. Tal ideal de intersubjetividade entre o enfermeiro e o usuário é baseado na crença de que aprendemos uns com os outros como seres humanos, identificando-nos com os outros ou encontrando os dilemas em nós próprios. O que todos ganham com isso é o autoconhecimento;

- Eu: é a Gestalt conceitual organizada, composta de percepções de características do "eu" e percepções do relacionamento do "eu" com os outros e com vários aspectos da vida;

- Tempo: a ocasião real do cuidar num momento presente tem o potencial de influenciar no futuro tanto o enfermeiro quanto o usuário. A ocasião do cuidar torna-se então parte do subjetivo, da realidade vivida e da história de vida de ambos. São ambos coparticipantes ao tornarem-se no agora e no futuro; são partes de um padrão de vida mais amplo, mais profundo e complexo.

\subsubsection{O poder do campo energético no cuidado transpessoal}

Teóricas de enfermagem como Newman (1992), Parses (1981) e Rogers (1970) definiram seres humanos como campos de energia: sistemas abertos envolvidos em trocas contínuas de energia; e essa abordagem de campos de energia é importante para o entendimento do cuidado transpessoal, proposto por Jean Watson.

Borges \& Santos (2013) reafirmam que o cuidado de enfermagem está envolvido num campo energético motivado por uma disponibilidade interna genuína do enfermeiro. Essa 
disponibilidade cria condições favoráveis ao restabelecimento de saúde, enquanto a indisponibilidade interna para o ato de cuidar desfavorece a recuperação de pacientes.

Esse argumento também é proposto pela teoria do cuidado transpessoal de Jean Watson que propõe a intervenção consciente nos cuidados, potencializando a restauração da saúde em sua integridade (BORGES; SANTOS, 2013).

Em seus construtos teóricos, Watson (2002a) afirma que as emoções são correntes de energia com frequências diferentes. Emoções consideradas negativas, como o ódio, a inveja, o desdém e o medo, têm uma frequência mais baixa e menos energia do que as emoções consideradas positivas, como o afeto, a alegria, o amor, a compaixão e o cuidar. Quando se decide substituir a corrente de baixa frequência, como a ira, por uma corrente de frequência mais elevada, como o perdão (cuidar, amor) aumenta-se a frequência de energia (WATSON, 2002a).

Neste sentido, pensamentos de vingança, violência, ganância, por exemplo, criam emoções como raiva, ódio, inveja, medo. Essas correntes de baixa energia baixam a frequência da luz ou consciência. Pensamentos criativos, de amor ou de cuidar, suscitam emoções de alta frequência e elevam a frequência do nosso sistema (WATSON, 2002a).

$\mathrm{Se}$ os pensamentos forem pensamentos que desenvolvam correntes de baixa frequência, os sistemas físicos e emocionais vão deteriorar-se e poderá apresentar a doença emocional e/ou física (WATSON, 2002a):

\footnotetext{
Pela seleção dos nossos pensamentos e selecionando que correntes emocionais vamos libertar e que reforçaremos, determinamos a qualidade da nossa luz. Determinamos os efeitos que iremos exercer nos outros e a natureza das nossas experiências de vida (WATSON, 2002, p.94).
}

Desta maneira, se o enfermeiro estiver atento à luz da própria consciência e da consciência do seu paciente, ele será capaz de expandir a atenção e alcançar um nível de cuidado mais elevado. Neste momento, encontra-se o que se chama de cuidado transpessoal (WATSON, 2002).

O enfermeiro, trabalhando com diferentes sistemas de emoções, deve estar atento ao fato de que "sistemas de baixa frequência retiram energia de sistemas de alta frequência". Se ele não estiver atento às próprias emoções, pensamentos e consciência, a sua energia pode ser diminuída por outro (neste caso, um paciente) que tem uma frequência mais baixa do que a dele (WATSON, 2002a).

Isso faz com que o enfermeiro deva optar por centrar sua consciência e intencionalidade do cuidado nas virtudes mais elevadas em vez de centrar nas falhas e 
defeitos dos outros; consequentemente terá uma energia de frequência mais elevada. A compaixão, a serenidade de temperamento, o amor, o cuidar e o perdão fluem através do corpo e chegam até os outros. Assim o cuidado transpessoal será efetivo (WATSON, 2002a).

Watson defende que esta consciência de cuidar, de energia e de conexão, de um para o outro, tem um potencial de cura. $\mathrm{O}$ enfermeiro adepto ao cuidado transpessoal entende que o cuidar é, sobretudo, um modo de ser; aquele que cuida tem pensamentos de alta frequência e a consciência de cuidar; esta frequência mais elevada da consciência de cuidar, por sua vez, ajuda a tranquilizar, a acalmar ou a potenciar o todo de uma pessoa com um sistema de baixa frequência - o que frequentemente é o caso se alguém está doente ou em sofrimento (WATSON, 2002a).

Unidas ao conceito de energia, outras modalidades do cuidar transpessoal são propostas por Jean Watson, tais como: as artes, o toque terapêutico, a música, a massagem e a visualização. Situadas num paradigma transpessoal, essas modalidades devem ser integradas na prática clínica da enfermagem convencional (WATSON, 2002a).

\subsubsection{Caritative Factors/Clinical Caritas Process}

Watson (2002), para sustentar suas matrizes conceituais, inicialmente estabeleceu pilares denominados Caritative Factors que norteiam sua concepção de Cuidado Transpessoal, em que o Processo Interacional Paciente-Profissional é direcionado a partir da tríade Mente-Corpo-Espírito.

Assim, os dez princípios elementares para a prática da Enfermagem, segundo os Caritative Factors, são:

1. A formação de um sistema de valores humanístico-altruísta: essa formação começa no início do desenvolvimento humano, com pouca idade, compartilhando os valores dos pais. Enquanto a personalidade da pessoa ainda está em formação esse sistema de valores é mediado por meio das próprias experiências de vida, do conhecimento adquirido e da exposição ao que é humano. Nesse sentido, os pontos de vista, crenças, interações e experiências pessoais são importantes para a construção e promoção dos próprios valores;

2. Estímulo da fé e esperança: o estímulo é essencial tanto para os processos de cuidados paliativos quanto para os curativos; o enfermeiro precisa transcender ao impulso de aceitar apenas a medicina ocidental e auxiliar a pessoa a entender as alternativas como a meditação ou o poder de cura da crença em si ou no aspecto 
espiritual. A esperança é fundamental e interfere na cura da doença, pois ajuda o paciente a aceitar informações sobre a doença e empenhar-se na mudança de atitude e comportamento na busca da saúde;

3. O cultivo da sensibilidade para si mesmo e para os outros: faz-se necessário explorar a necessidade de o enfermeiro começar a sentir a emoção como ela se apresenta, pois apenas por meio do desenvolvimento dos próprios sentimentos que a pessoa pode, verdadeira e sensivelmente, interagir com os outros. Quanto mais sensíveis, mais autênticos os enfermeiros se tornarão. Tornar-se autêntico encoraja o autocrescimento e a autoatualização tanto do enfermeiro quanto daqueles com quem ele interage. A insensibilidade quanto aos próprios sentimentos impede o desenvolvimento da sensibilidade para com as pessoas;

4. O desenvolvimento do relacionamento de autoconfiança: revelar a qualidade de um relacionamento com outra pessoa é o elemento mais significativo para a prestação de cuidados terapêuticos. Define o modo de comunicar e estabelece uma relação harmônica e cuidadosa, podendo ser verbal e não verbal. Ressalta-se que a forma como essa comunicação será desenvolvida pode estabelecer a confiança durante a assistência de enfermagem e o paciente perceberá que o enfermeiro realmente se preocupa e identifica suas necessidades individuais. Watson utilizou estudos de Rogers, Carkhuff e Gazda para definir as características necessárias no relacionamento de ajuda-confiança;

5. A promoção e aceitação da expressão de sentimentos positivos e negativos: ao tomar consciência sobre os próprios sentimentos, pode-se compreender 0 comportamento que ele origina. O comportamento é influenciado diretamente pelas emoções e são essenciais ao ser humano. Se houver uma incoerência entre pensamentos e sentimentos, isso pode levar à ansiedade, tensão, confusão, medo, ou mesmo alteração do entendimento e das atitudes frente ao problema;

6. O uso sistemático do método científico de solução de problemas para tomar decisões: esse fator discorre sobre a importância de elaborar planos e programas; avaliar, julgar, corrigir e decidir em relação à prática da enfermagem, tendo como fundamento a abordagem científica. Isso ajuda na tomada de decisão em todas as situações da enfermagem. Nessa questão Watson mostra-se a favor da necessidade do método científico, mas defende o uso criativo de todas as maneiras de conhecer (senso comum, ético, estético e religioso), como parte do processo de cuidar. 
Sugere o desenvolvimento de outros métodos de conhecimento para proporcionar um cuidado sob a perspectiva holística e integral;

7. A promoção do ensino-aprendizagem interpessoal: proporciona à pessoa maior controle sobre sua própria saúde, pois fornece tanto a informação necessária quanto às alternativas para solução do problema. Nesse contexto o enfermeiro deve enfocar a promoção do ensino-aprendizagem interpessoal, pois ajuda à pessoa a enfrentar o estresse, reduzir o medo, a ansiedade relacionada com a incerteza e a gravidade de sua condição clínica. Além disso, por meio da promoção do ensinoaprendizagem interpessoal, buscam-se soluções alternativas para a situação vivenciada e assume-se o controle da sua saúde;

8. A provisão de um ambiente mental, físico, sociocultural e espiritual sustentados, protetor e corretivo: esse item trata das funções diárias de rotina. A manutenção de um ambiente mental, físico, sociocultural e espiritual sustentador, protetor e corretivo, contribui para o bem-estar da pessoa. Por meio desse ambiente, o enfermeiro tem condições de promover saúde, restaurá-la ou prevenir doenças. Watson divide esse fator em variáveis externas (fatores físicos, de segurança e ambientais) e internas (atividades mentais, espirituais e culturais), sendo que o enfermeiro, ao acessar essas variáveis, pode proporcionar apoio e proteção para o bem-estar físico, mental e espiritual do indivíduo. Este fator revela a necessidade de o enfermeiro conhecer e respeitar a espiritualidade de cada paciente e dar oportunidade para que ele se expresse. Assim, o ambiente deve ser agradável de tal forma que não interrompa a privacidade, a segurança e o conforto do indivíduo;

9. Auxílio com a gratificação das necessidades humanas: baseia-se na hierarquia de cuidados similar de Maslow. Watson descreve o cuidado tanto em termos filosóficos quanto científicos. Além disso, estabeleceu uma ordem de necessidades humanas: necessidades de ordem inferior (essenciais para a sobrevivência) como as biofísicas (alimentação, eliminação, ventilação) e as psicofísicas (necessidades funcionais, como atitude e sexualidade); necessidades de ordem superior (enfatiza o potencial de desenvolvimento humano, a maturidade, a satisfação tanto pessoal quanto para com as outras) como as psicossociais (necessidades integradoras aquisição e filiação) e a intrapessoal e interpessoal (necessidade de busca de crescimento - autoatualização e autorrealização). Cada necessidade deve ser vista no contexto de todas as outras e não se deve descartar a necessidade de considerar cada pessoa no contexto global. A Ciência do Cuidar sugere que o enfermeiro 
reconheça e auxilie cada uma das necessidades inter-relacionadas do indivíduo para que ele seja ajudado a atingir a necessidade de autorrealização;

10. Aceitação das forças existencial-fenomenológicas: busca dar abertura e atenção aos mistérios espirituais e dimensões existenciais da vida-morte, cuidar da própria alma a do ser cuidado. Este fator faz uma reflexão do uso da fenomenologia e da psicologia existencial na assistência de enfermagem, pois Watson sugere que cada enfermeiro, além de dar atenção às questões espirituais de seus pacientes, deve olhar para o seu interior e encarar as próprias questões existenciais antes de ser capaz de auxiliar os outros a enfrentarem seus problemas.

Após a criação dos Caritative Factors, Watson (2008) aprimorou e lançou uma nova terminologia definida como Clinical Caritas Process. Assim, os dez Caritative Factors foram substituídos pelo Clinical Caritas Process, que configura os atributos para o acesso à dimensão espiritual. São eles:

Quadro 3 - Comparativo entre o Caritative Factors (1979) e o Clinical Caritas Process (2008)

\begin{tabular}{|c|c|}
\hline Caritative Factors & Clinical Caritas Process \\
\hline $\begin{array}{l}\text { A formação de um sistema } \\
\text { de valores humanístico- } \\
\text { altruístas. }\end{array}$ & Prática do amor/amabilidade e equidade para Si/Outro. \\
\hline Estímulo da fé e esperança. & $\begin{array}{l}\text { Estar autenticamente presente; possibilitar sustentar e } \\
\text { honrar profundamente o sistema de crença e o mundo } \\
\text { subjetivo do Outro/Si. }\end{array}$ \\
\hline $\begin{array}{l}\text { O cultivo da sensibilidade } \\
\text { para si mesmo e para os } \\
\text { outros. }\end{array}$ & $\begin{array}{l}\text { Cultivo de uma prática espiritual própria e um "self" } \\
\text { transpessoal que vai para além do próprio ego. }\end{array}$ \\
\hline $\begin{array}{l}\text { Desenvolver relacionamento } \\
\text { de autoconfiança. }\end{array}$ & $\begin{array}{l}\text { Desenvolvimento e permanência de uma autêntica relação } \\
\text { de cuidado. }\end{array}$ \\
\hline $\begin{array}{l}\text { A promoção e aceitação da } \\
\text { expressão de sentimentos } \\
\text { positivos e negativos. }\end{array}$ & $\begin{array}{l}\text { Estar presente para apoiar a manifestação de sentimentos } \\
\text { positivos e negativos como um meio de conexão profunda } \\
\text { consigo e com o paciente a ser cuidado. }\end{array}$ \\
\hline
\end{tabular}


O uso sistemático do método Uso criativo do "self" e de todos os outros conhecimentos científico de solução de reconhecidos como parte do processo de cuidar para o problemas para tomar engajamento em um processo de recuperação de saúde por decisões. intermédio da arte.

A promoção do ensino- Engajar-se verdadeiramente nas experiências de ensinoaprendizagem interpessoal. aprendizagem dentro do contexto do cuidar; atender a outra pessoa integralmente.

A provisão de um ambiente Criação de um envolvimento saudável em todos os níveis, mental, físico, sociocultural e tanto físico como não-físico, consciencial e espiritual sustentados, energeticamente refinado, pelo qual a totalidade, a beleza, o protetor e corretivo. conforto, a dignidade e a paz sejam potencializados.

Auxílio com a gratificação Com reverência e respeito, assistir às necessidades das necessidades humanas. humanas básicas; manter a intencionalidade consciencial do cuidado ao tocar e lidar com o espírito encarnado do outro, honrando a unidade do Ser; permitir a conexão espiritual.

Aceitação das forças Abertura e atenção à dimensão espiritual, misteriosa, existencial-fenomenológicas. desconhecida e existencial inerentes à Vida-MorteSofrimento.

Fonte: Penha (2012).

Para Watson (2002), o objeto de trabalho e estudo da Enfermagem é o cuidado humano. Os conceitos, modelos e teorias específicas de enfermagem devem ser verificados de forma organizada e estruturada, pois constituem importante ferramenta para aplicação prática no ensino, na pesquisa e na assistência. Nessa perspectiva, as teorias retratam não só a visão da realidade como também a compreensão das experiências dos profissionais (PESSOA; PAGLIUCA; DAMASCENO, 2006).

$\mathrm{Na}$ busca da integralidade dos cuidados, Jean Watson preocupa-se com o avanço tecnológico e que a priorização do saber técnico-científico sobreponha-se às necessidades da 
pessoa como um Ser que tem sua história no contexto familiar e social carregada de sentimentos, emoções e valores (TOMEY, ALLIGOOD, 2004; SILVA, 2011).

Assim, a Teoria do Cuidado Transpessoal desvia o foco da Enfermagem de seu atual modelo tecnicista para um modelo com ênfase na integralidade do cuidado e na busca de uma maior atenção aos aspectos sociais, emocionais e espirituais do paciente (SILVA, VALENTE, BITENCURT, BRITO, 2010).

Watson considera que o desafio atual da enfermagem é romper com os velhos laços da preocupação com os procedimentos, definições rígidas, racionalismo severo, operacionalismo, manipulação variável, e assim sucessivamente. A autora defende a necessidade de identificar outras vias de conhecimento e perspectivas alternativas da ciência, com abordagens adicionais para estudar e investigar a área da experiência humana na saúde-doença e no cuidar. Isso acontece pela defesa da autonomia da liberdade de escolha, que favorece o autoconhecimento e autocontrole do paciente (WATSON, 2002a).

Os objetivos para os ideais da sua teoria estão associadas a uma visão integral do ser humano e um crescimento mental-espiritual para o Eu e os Outros, encontrando significado na principal existência e experiência pessoal, descobrindo um poder e controle interiores e potencializando instâncias de transcendência e autorrecuperação (WATSON, 2002a).

Assim, nessa linha argumentativa, Jean Watson fundamentou sua teoria em fatores que facilitam a compreensão do papel da enfermagem frente à integralidade do cuidado.

O profissional de saúde envolvendo-se nesta perspectiva detém uma consciência e intencionalidade de cuidar no sentido do todo como um ideal moral, e não uma técnica interpessoal. Neste modelo, olhamos para além da doença externa per si. O cuidar transpessoal procura fontes mais profundas de cura interior, definida mais em termos espirituais do que em eliminação da doença (WATSON, 2002a, p. 117).

Esta perspectiva transpessoal requer um compromisso com um fim particular: a proteção, o aumento e a preservação da dignidade, da humanidade, do todo e da harmonia interior; contemplar objetivos de autoconhecimento, autocontrole e de cuidar, e mesmo a possibilidade de autorrecuperação (WATSON, 2002a). 


\section{O MÉTODO}

\subsection{TIPOLOGIA DO ESTUDO}

Para alcançar os objetivos enunciados, optou-se por realizar um estudo exploratório e descritivo, em uma abordagem qualitativa, embasada no referencial teórico de fenomenologia.

O método qualitativo é o que se aplica ao estudo da história, das relações, das representações, das crenças, das percepções e das opiniões, produtos das interpretações que os humanos fazem a respeito de como vivem, constroem seus artefatos, e a si mesmos, sentem e pensam (MINAYO, 2007, p. 57).

Os estudos da fenomenologia relatam que o fenômeno é uma compreensão advinda da interpretação. A Fenomenologia possibilita ao investigador aceitar os resultados da experiência vivida pela pessoa como afirmativas que têm significados para ela. A interpretação refere-se ao fenômeno que é percebido e vivido, ou seja, é tudo que faz parte de um contexto que não se mensura. Na realidade trata-se apenas de interpretar a existência experienciada dos participantes (TRIVIÑOS, 1992).

A pesquisa fenomenológica na enfermagem aponta para os fenômenos adoecer, morrer, relacionar-se com o outro, fenômenos esses que não podem ser compreendidos isolados da pessoa que os vivencia na totalidade de sua existência. Ou seja, é preciso compreender o fenômeno a partir do ser que o vivencia, dentro do contexto de seu existir (CAPALBO, 1994).

Para Minayo (2007), o surgimento de linhas holísticas na concepção de saúde e da doença deu abertura para discutir questões como: (a) a saúde tem de ser pensada como um bem-estar integral: físico, mental, social e espiritual; (b) os indivíduos devem assumir sua responsabilidade inalienável diante das questões de sua saúde; (c) as práticas da medicina holística devem ajudar as pessoas a desenvolver atitudes, disposições, hábitos e práticas que promovam seu bem-estar integral; (d) necessidade de se desenvolver uma filosofia no âmbito da saúde que formule uma concepção de saúde e de doença com relevância antropológica, levando em conta, também, fenômenos como religião e crenças de sociedades em grupos específicos.

Vasconcelos (2006) relata que a visão biopsicossocial de ser humano está transformando-se em uma visão que abrange, ainda, os aspectos ecológico e espiritual deste ser humano. Pode-se pensar na relevância de se compreenderem, através dessa descrição, as diversas percepções dos sujeitos em relação à espiritualidade como estratégia de enfrentamento frente à existência de uma realidade de hospitalização. 
A visão do fenômeno saúde, não limitada às causas e aos sintomas, pode ser traduzida através do método fenomenológico, ampliando-o para uma perspectiva multifacetada mediante os diversos fatores de ordem econômica, política, social, psicológica, cultural e espiritual com os quais se inter-relaciona (GOMES et al., 2008).

\subsection{SUJEITOS DO ESTUDO}

Os sujeitos deste estudo foram enfermeiros e enfermeiras, bem como pacientes internados em um hospital universitário do Distrito Federal.

\subsection{LOCAL DO ESTUDO}

O local do estudo foi a Clínica Médica do Hospital Universitário de Brasília (HUB).

\subsection{CRITÉRIOS DE INCLUSÃO}

Enfermeiros ou enfermeiras lotados na unidade de Clínica Médica que concordaram em participar da pesquisa; graduados e lotados no setor há mais de seis meses. A escolha desse critério buscou privilegiar maior contato com a vivência e experiência da realidade dos profissionais no referido setor.

Pacientes acima de 18 anos em tratamento clínico em regime de internação, que concordaram em participar da pesquisa; com prognóstico de permanência de, no mínimo, 48 horas, a partir da entrevista.

\subsection{CRITÉRIOS DE EXCLUSÃO}

Os critérios de exclusão para os enfermeiros foram: enfermeiros ou enfermeiras que não concordaram com a pesquisa; lotados no setor há menos de seis meses; em férias ou licença no período da coleta de dados.

Os critérios de exclusão para os pacientes foram: pacientes internados na clínica em caráter de hospital-dia; debilitados fisicamente e/ou com dificuldade de verbalizar ou expressar palavras, emoções, sensações e opinião, pacientes que não concordaram com a pesquisa. 


\subsection{PROCEDIMENTOS DE COLETA DE DADOS}

Os dados foram coletados por meio de um roteiro de entrevistas semiestruturadas sendo realizada em duas fases:

- Fase 1: A primeira fase ocorreu após a aprovação do projeto de pesquisa pelo Comitê de Ética e Pesquisa da Faculdade de Ciências da Saúde da Universidade de Brasília. Nesse momento, o pesquisador entrou em contato com a chefia da unidade de Clínica Médica do HUB para apresentar o estudo e conhecer as normas e rotinas do local. A escolha desse setor deve-se ao fato de a permanência dos pacientes ser mais longa e permitir melhor acompanhamento dos mesmos pelo pesquisador. Esta primeira fase aconteceu durante o mês de julho de 2014;

- Fase 2: A segunda fase iniciou-se após a autorização da chefia da unidade. O pesquisador fez uma visita inicial à Clínica Médica, a fim de identificar os sujeitos que iriam compor o universo desta pesquisa (enfermeiros, enfermeiras e pacientes), de acordo com os critérios de inclusão e exclusão. Nesse momento, o pesquisador iniciou o contato de sensibilização por meio da apresentação do estudo, explicitando suas fases e seus objetivos aos sujeitos. Após a aceitação e assinaturas dos TCLE (Apêndices 1 e 2), foram realizadas entrevistas semiestruturadas (Apêndices 3 e 4). Essa fase foi realizada durante os meses de agosto e setembro de 2014.

Essa segunda fase de coleta de dados foi a mais difícil de ser executada, visto que para a realização da entrevista com os enfermeiros eram necessários tempo e local adequados. Primeiramente, optou-se por determinar um horário com eles após o período de trabalho. Porém, essa estratégia não obteve êxito devido à indisponibilidade de alguns enfermeiros e a necessidade de sair do local da entrevista para assumir plantão em outro hospital. Assim, passou-se a acompanhar a escala de plantões e as atividades desenvolvidas durante os períodos de trabalho dos enfermeiros. Eu aguardava os momentos mais tranquilos durante os plantões para abordar os enfermeiros que estavam escalados e convidá-los para participar das entrevistas. Devido a esse contexto, o pesquisador teve que comparecer ao local do estudo muitas vezes até que essa etapa fosse concluída, incluindo-se visitas no período da manhã, tarde, noite e fins de semana.

A receptividade por parte dos enfermeiros foi bastante interessante devido ao ineditismo do tema da pesquisa. Observou-se que os técnicos de enfermagem queriam também participar da pesquisa, já que muitas entrevistas foram realizadas no posto de enfermagem. Explicou-se aos mesmos que o estudo tinha sido desenhado metodologicamente 
para ouvir apenas os enfermeiros, já que os mesmos são legalmente responsáveis pela prescrição dos cuidados de enfermagem.

Vale ressaltar que, ao iniciar os contatos com os enfermeiros, verificou-se que a maioria deles eram recém-concursados e lotados na Clínica Médica há menos de seis meses, sendo o mais antigo empossado há seis meses e o mais novo há duas semanas. Esse aspecto deveu-se ao fato de a gestão do Hospital Universitário de Brasília ter sido assumida pela Empresa Brasileira de Serviços Hospitalares (EBSERH) e a mesma ter realizado concurso público recentemente.

Dessa forma, para não prejudicar a pesquisa, optou-se por abrir mão do critério de inclusão de lotação mínima de seis meses no campo de estudo. Mas, apesar do pouco tempo de lotação na Clínica Médica (média de 2,5 meses), 06 (50\%) enfermeiros entrevistados possuíam mais de cinco anos de formado. Assim, muitos deles já acumulavam experiência prévia nas práticas do cuidado em enfermagem.

A coleta de dados com os pacientes foi realizada preferencialmente no início da noite. Esse horário foi escolhido, porque, por tratar-se de um hospital universitário, registra-se uma movimentação intensa de profissionais e estudantes no setor durante o dia. À noite, a maioria dos procedimentos médicos e de enfermagem, além das visitas multiprofissionais, já haviam sido realizados. Isso facilitou a aproximação do pesquisador com os pacientes e uma maior tranquilidade para os pacientes discutirem as questões sugeridas no roteiro de entrevista semiestruturada. A escolha dos pacientes privilegiou aqueles que estavam sem acompanhantes ou com apenas outro paciente na enfermaria. Quando existiam dois pacientes no mesma enfermaria, optou-se por realizar a entrevista com os dois. Esse critério foi bastante interessante, pois a conectividade $\mathrm{do}(\mathrm{s})$ paciente(s) com o pesquisador foi intensa, favorecendo um envolvimento maior de todas as partes envolvidas.

\subsection{PROCEDIMENTOS DE ANÁLISE}

Os dados obtidos por meio das entrevistas foram transcritos e o corpus das entrevistas submetidos à análise com auxílio do software Alceste (análise lexical por contexto de um conjunto de segmentos de texto).

Este software analisa qualitativamente os dados textuais e tem como base as leis de distribuição do vocabulário nos textos, sejam de origem verbal ou escrita. A análise estatística propõe desvendar as informações essenciais contidas no texto, obtendo assim enunciados simples. As palavras características desses enunciados são identificadas e contribuem para o 
refinamento a partir da análise do Qui-Quadrado (teste estatístico não paramétrico), das associações de palavras dentro de classes estudadas e na análise fatorial de correspondência mútua.

Ao analisar o corpus das entrevistas, o programa identifica as Unidades do Contexto Inicial (cada entrevista) e, em seguida, fragmenta-as e classifica-as em unidades menores, chamadas de Unidades de Contexto Elementar (UCE). Essas UCEs são compostas de enunciados linguísticos que compõem a entrevista. Após a identificação e a classificação dessas UCEs, o Alceste verifica a existência de repetições, baseadas em contextos de semelhança, identificando os contextos-tipo, ou seja, contextos que se reproduzem nas entrevistas. A análise estatística, que possibilita a identificação do contexto-tipo, é a Classificação Hierárquica Descendente (CHD), que separa esses contextos-tipo em classes/categorias e apresenta as relações entre elas sob a forma de dendograma. Em seguida, efetua-se uma Análise de Correspondência (AC), ou seja, um plano fatorial que permite a visualização de possíveis oposições entre as classes/categorias. Mediante essas análises, e a partir de uma leitura exaustiva das entrevistas, o pesquisador busca reconstituir o discurso coletivo dos sujeitos (RIBEIRO, 2005).

Assim, buscaram-se desvelar os contornos do objeto do estudo, tomando como referência distintos estudos até obter-se o estado final da análise e interpretação que será apresentado na discussão do estudo.

\subsection{PROCEDIMENTOS ÉTICOS}

O projeto de pesquisa foi encaminhado para análise e apreciação do Comitê de Ética em Pesquisa da Faculdade de Ciências da Saúde da Universidade de Brasília, observando a Resolução $n^{\circ}$ 466, de 12 de dezembro de 2012, do Conselho Nacional de Saúde, garantindo aos sujeitos envolvidos na pesquisa a preservação dos dados e a confidencialidade pela participação na pesquisa. O projeto foi aprovado sob o parecer $n^{\circ} 714.467$ de 09/07/2014 (Apêndice 5).

Foi elaborado, seguindo as recomendações da Resolução no 466/2012, o Termo de Consentimento Livre e Esclarecido - TCLE, tanto para os enfermeiros e enfermeiras quanto para os pacientes, assegurando o resguardo de qualquer constrangimento e/ou risco de acidentes envolvidos no estudo (Apêndices 1 e 2).

Após aprovação pelo Comitê de Ética da faculdade, o projeto foi encaminhado ao Comitê de Ética do Hospital Universitário de Brasília para coleta de dados. 


\section{RESULTADOS E DISCUSSÃO}

\subsection{PERFIL DOS ENFERMEIROS}

Participaram do estudo 12 enfermeiros, lotados na Clínica Médica do Hospital Universitário de Brasília (HUB), no período compreendido entre os meses de julho e setembro de 2014. Desses enfermeiros, quatro (04) trabalhavam no turno da manhã, três (03) no turno da tarde e cinco (05) no turno da noite. O perfil dos participantes ficou composto da seguinte maneira: $10(83,3 \%)$ eram do sexo feminino e 2(16,7\%), do sexo masculino.

Em relação à Instituição formadora, 08 (oito) profissionais declararam ter realizado o curso em instituição privada (66\%), enquanto 4 (34\%) eram oriundos de instituição pública. O tempo médio de formação foi de 8,1 anos, sendo que $4(33,6 \%)$ profissionais tinham concluído a graduação há menos de 3 anos; 2(16,6\%), entre $3-5$ anos; 2(16,6\%) entre 5 - 10 anos; 2(16,6\%) entre 10 - 15 anos e 2(16,6\%) tinham mais de 15 anos de formado.

Quanto à região do país onde se graduaram, 8(66\%) dos enfermeiros estudaram em instituições superiores da região Centro-Oeste; 3(25\%), na região Nordeste e 1 (9\%), na região Sudeste.

O tempo de experiência dos enfermeiros na Clínica Médica variou entre duas semanas e 6 meses, com média de 2,5 meses. Entre esses profissionais, 3(25\%) trabalhavam na Clínica Médica há aproximadamente um mês; 7(58\%), entre 1 - 3 meses e 2(17\%), acima de 3 meses.

Questionados se professavam alguma religião, 7(58\%) consideravam-se católicos; 2 (17\%), espíritas; 2(17\%) se declararam cristãos, mas sem religião; e 1(8\%), presbiteriano.

Na Tabela 1 apresenta-se o perfil de acordo com o sexo, idade, instituição, tempo de formação, tempo de atuação na Clínica Médica e religião. 
Tabela 1 - Perfil dos enfermeiros que atuam no cenário da pesquisa. Brasília, 2014.

\begin{tabular}{|c|c|c|c|c|}
\hline & Variáveis & $\begin{array}{c}\text { Mulheres } \\
\mathbf{n}^{0}(\%)\end{array}$ & $\begin{array}{c}\text { Homens } \\
\mathbf{n}^{0}(\%)\end{array}$ & $\begin{array}{c}\text { Total } \\
n^{0}\end{array}$ \\
\hline Sexo & & $10(83,3)$ & $2(16,7)$ & 12 \\
\hline Instituição & Pública & $4(40)$ & - & 4 \\
\hline \multirow[t]{3}{*}{ de Formação } & Privada & $6(60)$ & $2(100)$ & 8 \\
\hline & Total & $10(100)$ & $2(100)$ & 12 \\
\hline & $0-1$ ano & $1(8,3)$ & - & 1 \\
\hline Tempo de & $1-3$ anos & $2(16,7)$ & $1(50)$ & 3 \\
\hline \multirow[t]{6}{*}{ Formação } & $3-5$ anos & $1(8,3)$ & $1(50)$ & 2 \\
\hline & $5-10$ anos & $2(16,7)$ & - & 2 \\
\hline & $10-15$ anos & $2(16,7)$ & - & 2 \\
\hline & Mais 15 anos & $2(16,7)$ & - & 2 \\
\hline & Total & $10(100)$ & $2(100)$ & 12 \\
\hline & Centro-Oeste & $7(70)$ & $1(50)$ & 8 \\
\hline Região de & Nordeste & $3(30)$ & - & 3 \\
\hline \multirow[t]{3}{*}{ Formação } & Sudeste & - & $1(50)$ & 1 \\
\hline & Total & $10(100)$ & $2(100)$ & 12 \\
\hline & Católica & $6(50)$ & $1(50)$ & 7 \\
\hline \multirow[t]{4}{*}{ Religião } & Espírita & $2(25)$ & - & 2 \\
\hline & Presbiteriana & - & $1(50)$ & 1 \\
\hline & Cristão (s/religião) & $2(25)$ & - & 2 \\
\hline & Total & $10(100)$ & $2(100)$ & 12 \\
\hline
\end{tabular}

Fonte: Dados da pesquisa.

O perfil dos participantes da pesquisa ratifica o estudo encomendado pelo Conselho Federal de Enfermagem, realizado pela FIOCRUZ e publicado em maio de 2015, buscou traçar o perfil da Enfermagem brasileira e apontou que a equipe de enfermagem no Brasil é formada predominantemente pela presença feminina, sendo composta por $84,6 \%$ de mulheres (FIOCRUZ, 2015).

Os dados apresentados por Teixeira et al. (2013) foram semelhantes aos desta pesquisa e apontam que os profissionais de enfermagem que atuam na região centro-oeste brasileiro são, em sua maioria, formados em instituições particulares. Os autores citam que as políticas adotadas pelo governo federal brasileiro incentivaram o crescimento do setor privado, e, nos últimos dez anos, foi observado um incremento de 393\% do número de cursos nas instituições privadas em comparação aos $122 \%$ do número de cursos públicos. Em relação aos cursos de graduação em enfermagem, neste mesmo período, dos 838 cursos, 166 (21\%) 
eram em instituições públicas e 666 (79\%) em instituições privadas. Na região Centro-Oeste, também prevalece o setor de ensino privado na Enfermagem - 65 instituições privadas (78\%), em contrapartida com 18 instituições públicas (22\%). Isso determina, quase que por completo, o perfil dos futuros profissionais de enfermagem a serem inseridos no mercado de trabalho em saúde da região (TEIXEIRA et al., 2013).

Em relação ao tempo de formação, verificou-se que grande parte dos entrevistados era recém-formada ou com tempo de formação abaixo de cinco anos, 58\% deles finalizaram a graduação recentemente, aproximadamente nos últimos seis anos. Além disso, eram ingressantes no serviço público por meio de concurso. Esses resultados corroboram a pesquisa dos estudos de Albrecht \& Krawulski (2011), que demonstrou que os principais candidatos de concursos públicos são iniciantes em suas carreiras profissionais.

Em relação à religião, o resultado encontrado é semelhante aos dados apresentados no Censo Demográfico brasileiro de 2010, do Instituto Brasileiro de Geografia e Estatística (IBGE). O Censo demonstrou que a religião católica continua sendo a maior religião do país $(64,4 \%)$, embora haja uma maior diversidade religiosa da população brasileira (BRASIL, 2010).

Um dado interessante é que, apesar de 02 (16,7\%) enfermeiros referirem não terem religião, todos relataram que se consideravam cristãos. Isso aponta que todos os participantes da pesquisa consideram a religiosidade/espiritualidade como algo importante na vida humana.

\subsection{VIVÊNCIA DOS ENFERMEIROS FRENTE AO CUIDADO DA DIMENSÃO ESPIRITUAL DOS PACIENTES}

$\mathrm{Na}$ análise do conteúdo das entrevistas, emergiram dois eixos significativos. O primeiro eixo foi composto por uma categoria denominada A Lacuna na Formação e o segundo eixo por duas categorias, denominadas respectivamente Os Fatores que Influenciam a (Des)Integralidade do Cuidado e Os Fatores que Possibilitam uma Prática de Cuidado Integral conforme apresentado no dendograma a seguir. 


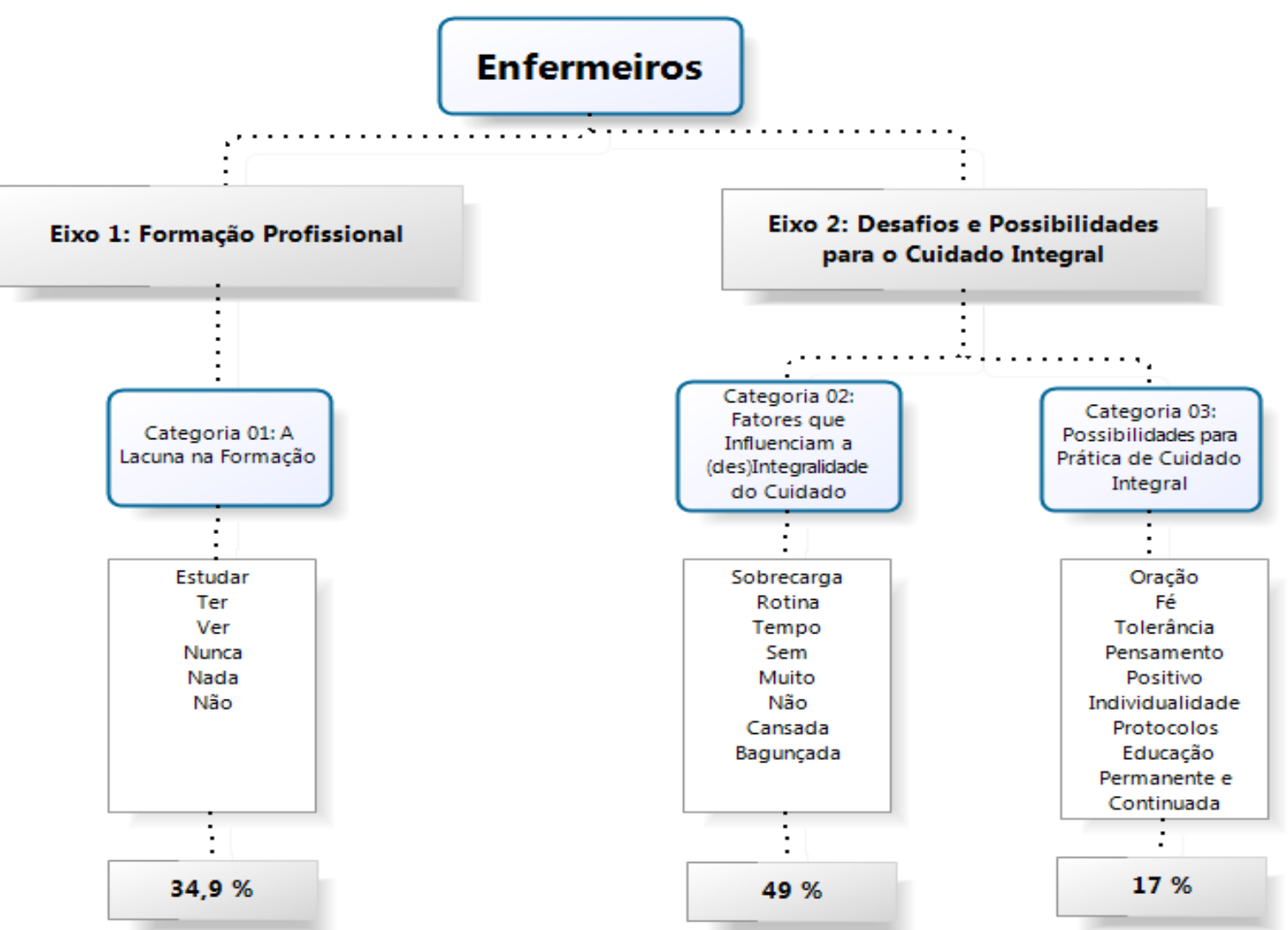

Figura 1: Dendograma com os eixos e categorias que emergiram da análise das entrevistas dos enfermeiros. Brasília, 2014

No eixo, denominado Formação Profissional, os sujeitos apontaram a existência de uma importante lacuna no que diz respeito a abordagem da dimensão espiritual durante o processo de formação e a prática de um cuidado integral de enfermagem. No segundo eixo, denominado Desafios e Possibilidades para uma prática Integral do Cuidado de Enfermagem, os enfermeiros identificaram os principais impedimentos da realização de um cuidado que atenda a dimensão espiritual no processo de cuidar e apontaram as possíveis estratégias e ações que podem favorecer o atendimento dessas necessidades. 


\title{
3.2.1 O Eixo da Formação Profissional
}

\begin{abstract}
O significado da prática de enfermagem nos manuais de enfermagem fundamentais é inquestionavelmente determinado por uma racionalidade e linguagem que favorece fortemente a enfermagem como sendo técnica. (Jean Watson)
\end{abstract}

Este eixo desvelou que existe uma lacuna na formação acadêmica dos sujeitos do estudo, quanto aos cuidados de enfermagem relativos à dimensão espiritual. Os resultados apontaram que os enfermeiros conhecem o significado do termo "integralidade", que vai ao encontro da abordagem utilizada no estudo, ou seja, referindo-se à necessidade de considerar todas as dimensões que envolvem o ser humano durante a prática do cuidado.

\footnotetext{
Eu acredito que a integralidade é você trabalhar com o paciente como um todo, né...Desde sua parte física, psicológica, social e espiritual também. Ter um olhar do paciente por completo...Um olhar holístico(E5).

O cuidado integral, na minha concepção, é um cuidado de uma forma holística ao paciente, né. A gente vai cuidar dele como um todo, não só em relação àquela patologia que ele tá apresentando no prontuário, mas como também verificar outras necessidades dele e incluir, também, o psicológico, o social, o físico né, o mental, tudo isso (E8).

A integralidade é um cuidado holístico, né, olhar o paciente como um todo, da cabeça aos pés, não só por fora, mas por dentro também...Respeitando a individualidade de cada um...A crença...E respeitando todos os outros fatores, raça, etnia, orientação sexual...Então é a gente olhar o paciente não só por fora, não só pela patologia, não olhar ele como um número, como é de costume, de praxe, né...Fulano de tal, duzentos e onze...E sempre ver esse paciente, que ele tem um nome, ele tem uma vida (E10).
}

Entretanto, apesar do entendimento correto sobre o cuidado integral, o atendimento das necessidades espirituais dos pacientes é outra questão. Eles foram enfáticos ao afirmar que o estudo das necessidades relativas à dimensão espiritual não tem sido abordada de maneira adequada durante a formação acadêmica. Dessa forma, atribuíram a esse fato as dificuldades da avaliação das necessidades espirituais dos seus pacientes.

Não tive nenhuma formação nessa parte de espiritualidade durante a minha faculdade. Na verdade não era abordada essa parte (E8).

Esse lado da espiritualidade da gente, eu acho que ninguém nunca estudou. Podem ter vários estudos, mas não focam nisso (E10).

Nunca tive nenhuma formação nessa parte de espiritualidade durante a minha faculdade. Na verdade não era abordada essa parte (E8).

Como vou dar aquilo que não sei, que não fui instruída pra dar? (E1). 


\subsubsection{A lacuna na formação}

Nesta categoria, a presença dos verbos lembrar, estudar, ter, ver, e dos advérbios de negação nunca, nada, não no discurso dos participantes do estudo, fazem referência às inadequações, ou mesmo à inexistência de discussões durante a graduação que incluíssem ou abordassem a dimensão espiritual nos cuidados de enfermagem. Os enfermeiros relataram que durante o período de graduação não lembram, não tiveram ou mesmo não viram nenhum aspecto relacionado às questões espirituais de seus pacientes. Os fragmentos dos discursos, a seguir, exemplificam essa situação:

Na minha formação eu acho que esse lado da espiritualidade nem foi abordado. Não me lembro de ter em algum momento ter sido abordado. Eu não tenho lembrança disso (E2).

Na minha época de formação não teve nada sobre isso de espiritualidade. E olha que foi há trinta e tantos anos que eu me formei (E3).

Na minha graduação, no máximo que eu tive foram orientações básicas de respeitar a religião de cada um, de não interferir na religião, alguma coisa nesse sentido. Mas, assim, uma orientação específica de como fazer, de como trabalhar a espiritualidade com o paciente, não (E12).

Os resultados corroboram estudos que apontam que, apesar de terem clareza sobre as dimensões que favorecem a integralidade do cuidado e reconhecerem que a espiritualidade é um aspecto fundamental da assistência de Enfermagem, muitos profissionais ainda se sentem hesitantes e com pouca confiança para abordar esses aspectos devido à falta de inclusão adequada dessa temática durante o processo de formação acadêmica (McSHERRY \& JAMIESON, 2011).

Essa questão também foi observada por Penha (2012) ao referir que a formação acadêmica dos enfermeiros não tem contemplado aspectos relacionados a questões de espiritualidade no cuidado. Segundo o autor, superficialmente trazem a discussão do atendimento humanizado, questões básicas de religiosidade, mas, mesmo assim, insuficientes para a construção de um plano de cuidados que aborde tais questões (PENHA, 2012).

Entretanto, concorda-se com a perspectiva de Vasconcelos (2006) ao explicitar que a espiritualidade deve estar presente nos espaços de formação profissional, dentro de uma pedagogia científica que valorize a discussão, a reflexão e a crítica. É necessário valorizar a espiritualidade na formação profissional por se tratar de uma exigência na realidade do trabalho em saúde. Não seria científico deixar de refletir e estudar a dimensão espiritual e não 
seria uma pedagogia científica que evitaria a sua discussão e o estudo nos espaços de formação profissional (VASCONCELOS, 2006).

Nessa linha argumentativa, Watson (2002) menciona que a formação do enfermeiro deve (re)valorizar o conceito de "alma" e de "espírito". Para ela, a alma refere-se ao espírito, ao "eu" interior ou à essência da pessoa, que está ligada a um sentido maior de conhecimento próprio, um grau de consciência mais elevado, uma força interior e um poder que pode expandir capacidades humanas e permitir que uma pessoa transcenda o seu "eu" habitual (WATSON, 2002).

Para Watson, a abordagem da dimensão espiritual nunca desapareceu, realmente, do ato da cura, pois a brecha entre a ciência e a espiritualidade não é tão ampla como se tinha pensado (WATSON, 2002a).

Nessa perspectiva, Watson sugere que será preciso forjar novas formas de pensar e sentir as vivências humanas reafirmando um elevado sentido de consciência e valorização do eu interior, embora a cultura racional e científica negue essas possibilidades (Watson, 2002). Entende-se que essas possibilidades devem ser valorizadas pela enfermagem.

Nesse sentido, para que a formação em enfermagem assuma um novo paradigma e que possa resgatar o cuidado espiritual em sua prática cotidiana, é preciso que os enfermeiros e a enfermagem se curem de um século de domínio do modelo biomédico, que valoriza a ciência positivista e a fragmentação do sujeito. A contínua aderência a esse modelo fragmentado da prática de enfermagem não tem sido adequado para abordar todo o fenômeno do cuidar e para dar respostas aos problemas de saúde atuais (WATSON, 2002a).

Watson (2002a) critica o modelo vigente de formação e atuação do enfermeiro, pois ao assumir um fazer essencialmente técnico esse profissional reproduz acriticamente o fazer do médico, distanciando-se da essência do cuidado de enfermagem. Observa-se que os enfermeiros assumiram muitas tarefas que previamente estavam dentro do domínio médico, tais como administração de medicamentos, avaliações físicas. Essas novas práticas foram cada vez mais valorizadas e difundidas nas instituições formadoras de enfermagem. Porém conceitos invisíveis como cuidar, confortar, ter compaixão, oferecer cuidados emocionais e espirituais foram colocados à parte dos cuidados de enfermagem (WATSON, 2002a).

Assim, reiterando o pensamento de Watson (2002a), a formação do enfermeiro deve reforçar valores como compaixão, gentileza, amor e responsabilidade mútua como maneiras eficazes de explorar a dimensão espiritual de seus pacientes.

Outra questão, apontada por Watson e que merece destaque, é a necessidade de repensar o modo de ensinar dos professores de enfermagem. Aqui se observa que há uma 
dicotomia na prática formativa. Apesar de muitos professores incentivarem seus alunos a serem autônomos, agentes de mudança e líderes, outros buscam educar seus alunos de maneira a se adequarem à lógica do mercado, em que instituições empregadoras recompensam a obediência aos preceitos médicos, ao cuidado biomédico e à conformidade com as normas e rotinas da instituição. Essas abordagens impedem os comportamentos criativos, inquiridores e ousados e sensíveis às reais necessidades dos pacientes (WATSON, 2002a).

Nesse sentido, a prática do cuidado espiritual de enfermagem precisa reencontrar espaço na formação do profissional de enfermagem. Novas estratégias de ensino da espiritualidade podem ser buscadas para suprir esta lacuna, tais como: incluir disciplinas específicas que contemplem o tema em seu Projeto Político Pedagógico e incentivar a pesquisa e extensão sobre cuidados espirituais.

Watson sugere que, durante a formação dos enfermeiros, os professores podem ajudálos a visualizarem os fenômenos humanos, e, em especial, a dimensão espiritual a partir de uma nova ou diferente perspectiva: talvez desenvolver ou tentar um novo ponto de partida, usando 'novas lentes' ao focar a atenção no fenômeno do comportamento humano em busca da promoção da saúde, prevenção ou cura da doença (WATSON, 2002a).

Ao incentivar o acesso ao mundo subjetivo e interior dos significados pessoais do próprio aluno e dos seus pacientes, o professor de enfermagem dará subsídios para seus alunos explorarem o mundo interior das experiências das relações humanas em vez de o mundo exterior da simples observação de sinais e sintomas (WATSON, 2002a).

A verbalização dos participantes desta pesquisa, de que durante a formação não tiveram contato algum com conhecimentos sobre a dimensão espiritual de seus pacientes, ratifica o pensamento de Watson, ao afirmar que a abordagem positivista-reducionista dominou a ciência e a medicina Ocidental, afetando, consequentemente, a prática de enfermagem (WATSON, 2002a).

Em consonância com essa realidade, observa-se que alguns professores de enfermagem e enfermeiros assistenciais têm admitido que existe uma inconsistência entre o paradigma da ciência moderna e a natureza do cuidado de enfermagem. Nessa linha, buscamse abordagens alternativas para desenvolver a ciência da enfermagem, além de buscar a (re)inclusão da espiritualidade nos cuidados dos pacientes (WATSON, 2002). 
Nas palavras de Watson:

é irônico que numa época de tanto avanço científico e tecnológico na medicina, exista a necessidade de (re)ligar o cuidado ao ser humano à um sentido misterioso, inatingível, filosófico e metafísico, algumas vezes até místico, para resolver algumas das doenças na sociedade, e o sofrimento associado com a desarmonia com a mente, corpo e espírito (WATSON, 2002, p. 74).

Vale ressaltar que, apesar de alguns sujeitos afirmarem ter tido algum contato com o tema espiritualidade durante o período de graduação, essas abordagens foram pontuais em determinados contextos na graduação. Alguns relataram ter tido certo contato com os temas em discussão referentes à Teologia, Humanização em Saúde, Saúde do Idoso, Saúde Mental e Psicologia; ou mesmo que dependia de cada professor a abordagem do tema.

Vê-se que, apesar de os enfermeiros saberem da existência da multidimensionalidade do ser humano e da integralidade do cuidado, a discussão sobre a dimensão espiritual ainda é incipiente no processo de formação do enfermeiro brasileiro. Seria necessária uma reformulação do projeto pedagógico dos cursos de graduação em enfermagem a fim de contemplar a dimensão espiritual nos cuidados integrais de saúde e de enfermagem. O que se observa nos relatos a seguir é a fragmentação do olhar dos cuidados em enfermagem:

Tive um módulo dentro da Psiquiatria. Dentro dele a gente abordou um pouco esse aspecto, mas nada direcionado à espiritualidade não (E1).

Tive uma disciplina chamada Teologia da Saúde, mas nela a gente discutia a importância de olhar o paciente como um todo $e$ respeitar a religião $e$ a individualidade do paciente (E5).

Na minha faculdade eu tive a Psicologia, mas não abordava, assim, profundamente, como cuidar a espiritualidade do paciente (E6).

Na Saúde do Idoso e na Saúde Mental a gente focou nesse aspecto da espiritualidade (E10).

Devido ao seu caráter subjetivo, a dimensão espiritual pode ser abordada sob diferentes ângulos. No âmbito da Psiquiatria, estudos demonstram que existe um valor positivo da integração da espiritualidade na prática clínica em saúde mental. Essa prática pode ser verificada em todas as fases do tratamento psíquico, desde a prevenção e promoção da saúde mental, até o enfrentamento das adversidades por parte dos pacientes psiquiátricos e seus familiares, na reabilitação e reinserção social (MOREIRA-ALMEIDA, 2012; KOENIG, 2007; GUIMARÃES \& AVEZUM, 2007; PERES, SIMÃO \& NASELLO, 2007). 
Para uma abordagem teológica, em especial na área da saúde, há tendência de relacionar a religiosidade às práticas de espiritualidade. Assim, ao abordar a Teologia em Saúde no âmbito da formação do enfermeiro, conceituações e virtudes religiosas como o perdão, altruísmo, esperança, prece e voluntarismo podem conduzir estudos de avaliação de espiritualidade e religiosidade por parte desses profissionais junto aos seus pacientes (GUIMARÃES \& AVEZUM, 2007).

No âmbito da Psicologia, as primeiras discussões sobre religiosidade/espiritualidade foram feitas por Freud, que as considerou como remédio ilusório contra o desamparo. Atualmente, a experiência religiosa e espiritual deixou de ser considerada fonte de patologia e, em certas circunstâncias, passou a ser reconhecida como provedora do reequilíbrio da saúde e da personalidade (Levin, 1996; Koenig, 2001a). Observa-se que no campo da psicoterapia a habilidade de inquirir sobre a vida religiosa e espiritual dos pacientes é um elemento importante da competência psicoterapêutica. A busca por questões relacionadas à vida religiosa e espiritual dos pacientes revela frequentemente dados importantes para a superação de suas dificuldades (PERES, SIMÃO \& NASSELO, 2007).

A abordagem da espiritualidade na saúde do idoso se deve ao fato, também, de que as necessidades espirituais crescem de significado à medida que a pessoa envelhece (LUCCHETTI, GRANERO, BASSI, 2010).

Dessa forma, pode-se dizer que apesar dos modismos, incentivados pelas novas demandas dos pacientes, o processo de ensino da enfermagem persiste em suas características do modelo médico biologizante que prioriza a superespecialização em detrimento da real apreensão das necessidades de quem cuida e de quem é cuidado, num contexto do cuidado integral.

\subsubsection{O Eixo dos Desafios e Possibilidades para o Cuidado Espiritual}

\subsubsection{Os Fatores que Influenciam a (Des)integralidade do Cuidado}

No discurso dos enfermeiros, os substantivos sobrecarga, rotina, tempo, os advérbios sem, não, muito, além dos adjetivos cansada, bagunçada evidenciam a existência de três pontos principais que motivam a (des)integralidade do cuidado e dificultam o atendimento da dimensão espiritual dos pacientes: o primeiro é a sobrecarga de trabalho, o segundo, a rotina voltada para o atendimento biológico baseado, sobretudo, em ações técnicas do cuidado de enfermagem, e o terceiro, a ambiência de cuidado. 
A sobrecarga de trabalho é destacada no fragmento de discurso a seguir:

A nossa equipe é muito sobrecarregada. Nossa sobrecarga de trabalho não permite que a gente faça um trabalho individualizado. Às vezes são dois enfermeiros para sessenta e sete pacientes. Então a gente fica enfermeiro bombeiro, apagando fogo pra tudo quanto é lado (E1).

Vale ressaltar que uma unidade de Clínica Médica deveria acolher pacientes de cuidados mínimos ou no máximo de cuidados intermediários. Segundo o Conselho Federal de Enfermagem- COFEN, o paciente de cuidados mínimos é aquele paciente estável, sob o ponto de vista clínico e de enfermagem, e fisicamente autossuficiente quanto ao atendimento das necessidades humanas básicas. Já os de cuidados intermediários, são aqueles pacientes estáveis, sob o ponto de vista clínico e de enfermagem, mas que requerem avaliações médicas e de enfermagem e apresentam parcial dependência dos profissionais de enfermagem para o atendimento das necessidades humanas básicas (COFEN, 2004).

Observa-se que na unidade de Clínica Médica do hospital onde foi realizado o estudo, há pacientes de cuidados semi-intensivos, intensivos e alguns em cuidados paliativos; essa realidade contribui para a sobrecarga da equipe de enfermagem. Apreendeu-se que aproximadamente 06 enfermeiros no plantão diurno e 04, no noturno se revezam para cuidar de 67 pacientes (capacidade máxima das duas alas). Acredita-se que exista um déficit de pessoal na unidade.

Muito provavelmente, em decorrência desse contexto, somado a outros, desvelou-se também que a rotina de cuidados é caracterizada pelo predomínio de ações técnico-biológicas no cuidado. Isso pode ser demonstrado nos relatos abaixo:

Eu aqui na Clínica Médica tenho que entender de tudo. Tenho paciente que é da Oncologia. Tenho que saber de todos os cuidados, intercorrências, tudo o que pode acontecer. Tenho paciente da Cardiologia e que preciso saber da bomba de heparina, amiodarona, do trombo do átrio direito. Tenho outro no box de emergência que está em respiração mecânica. Tenho que vir e ler o traçado de um eletrocardiograma. Como fazer tudo isso, individualizar meu cuidado e incluir a espiritualidade? É muito difícil (E1).

Muitas vezes a gente passa a visita de manhã, conversa com o paciente, vê como ele está, mas depois o foco mesmo é nos procedimentos que têm pra fazer e não deixar o paciente sem assistência. A rotina atrapalha porque você não vai ter aquele cuidado tão integral com aquele paciente. Ainda mais quando esse paciente necessita de cuidados paliativos (E7).

A rotina daqui não inclui esse aspecto espiritual. Não sei se pelo fato da rotina ser muito corrida, ter muitos pacientes, muitos procedimentos pra serem feitos, como colocação de sonda, curativos, abertura de prescrições...E às vezes tem que resolver os problemas que acontecem, encaminhar exames. Essa correria faz com que a gente não dê muita importância pra essas questões religiosas e espirituais (E8). 
Os relatos acima demonstram um modelo de cuidado que privilegia a doença e sua cura. Nesse sentido, as outras dimensões do ser humano têm sido desconsideradas na integralidade do cuidado. Observa-se que no setor existem pacientes que necessitam de cuidados paliativos. Nesse caso, o foco do cuidado de enfermagem precisa obrigatoriamente ser ampliado, indo além do atendimento das necessidades biológicas. O objetivo dos cuidados paliativos é oferecer o conforto e alívio necessários para atenuar o sofrimento do paciente e permitir-lhe manter a dignidade na hora do adeus à vida e aqui o atendimento das necessidades para um cuidado integral são fundamentais (Araújo et al., 2010). Assim, os pacientes em cuidados paliativos precisam de uma assistência humanizada que ofereça a eles e sua família o conforto nas dimensões física, social, emocional e espiritual.

A realidade do cuidado de enfermagem na Clínica Médica, mais uma vez, mostram que as ações de enfermagem continuam voltadas ao modelo biomédico. O confinamento do cuidado ao corpo-físico, com cinco sentidos separados (tato, olfato, visão, audição e paladar), transforma o paciente em corpo-objeto. Entretanto, apesar de esse enfoque ajudar a eliminar ou reparar doenças do corpo-físico, não consegue curar no nível transpessoal, interior, profundo (WATSON, 2002a).

Segundo Watson, a enfermagem no século XXI precisa repensar sua identidade, suas fronteiras, sua maturidade, seus paradigmas, sua educação e seus modelos de prática. Ou a enfermagem amadurece nas suas próprias práticas de cura ou permanecerá, como pensa Watson, numa posição técnica dependente, dentro do sistema patriarcal da medicina (WATSON, 2002a).

Uma forma de repensar essa identidade seria resgatar a espiritualidade no cuidado e buscar abordagens adicionais para estudar e investigar a área da experiência humana na saúde-doença. Dessa maneira, a enfermagem quebrará os laços da dependência com o tradicional método-científico e desenvolverá a própria herança científica (WATSON, 2002a).

Não se cogita que a enfermagem deva abrir mão da tecnologia, dos conhecimentos da ciência que ajudaram a avançar, mas, sim, que ela deve romper com os velhos laços da preocupação demasiada com os procedimentos técnicos, com as definições rígidas, do racionalismo severo (WATSON, 2002).

A identificação da realidade da Clínica Médica permite dizer que se faz necessária uma discussão sobre o redimensionamento de pessoal de enfermagem para melhor gestão do serviço da clínica. Pensa-se que uma possibilidade seria a divisão do setor em dois: um setor voltado para o atendimento das necessidades inerentes à Clínica Médica de pacientes com 
necessidades de cuidados mínimos e intermediários; e outro setor que atendesse os pacientes oncológicos e em cuidados paliativos. Essa divisão poderia favorecer e minimizar a sobrecarga de trabalho dos enfermeiros, a mudança na rotina e melhorar a ambiência de trabalho.

A ambiência de trabalho foi mencionada pelos enfermeiros como um aspecto que contribui para a (des)integralidade do cuidado, conforme relato a seguir.

Aqui na Clínica Médica tem muito serviço, muitos procedimentos. Muita bagunça, muita gritaria. Como trabalhar a espiritualidade do paciente nesse ambiente? (E12).

Para a implementação de cuidados integrais, e consequentemente a inclusão de cuidados espirituais, Watson (2002a) e Malkin (1992) sugerem que se faz necessária uma nova fronteira para o delineamento dos cuidados de saúde: os chamados ambientes de cura. Esses ambientes devem ser criados para atender à relação entre o estresse, a doença e os fatores de estresse hospitalares (WATSON, 2002a).

O ambiente de cura envolveria, por exemplo, redução do ruído e a introdução intencional da arte, música e mitologia como expressões de humanidade e cultura. Para Watson "estes aspectos do ambiente tocam no âmago mais profundo do nosso ser e podem ajudar a transcender a doença, a dor e o sofrimento, auxiliando-nos a recordar a nossa humanidade comum" (WATSON, 2002, p. 249).

De acordo com Watson (2002a), esse ambiente de cura reduz o período de internação dos pacientes, reduz os custos hospitalares e cria um sentido maior de harmonia, cura e resultados positivos com uma doença ou uma experiência hospitalar. Esse ambiente auxilia no cuidado transpessoal e, consequentemente, ajuda o enfermeiro a explorar a dimensão espiritual de seus pacientes (WATSON, 2002a).

O quadro a seguir destaca as ações que podem ser implementadas para que o ambiente possa se tornar um ambiente de cura, conforme a Teoria Transpessoal do Cuidado de Jean Watson. 
Quadro 4 - Aspectos importantes para um ambiente de cura

\begin{tabular}{|c|c|}
\hline Ambiente de Cura & Ações \\
\hline Controle do ruído & $\begin{array}{l}\text { Som de passos no corretor; bater de portas, tinido de fechaduras; } \\
\text { conversas da equipe; televisores e rádios dos doentes; ruído de pratos; } \\
\text { intercomunidadores. }\end{array}$ \\
\hline Qualidade do ar & $\begin{array}{l}\text { Necessidade de ar fresco, solário ou jardim exterior; evitar emanação } \\
\text { de gases nocivos dos materiais sintéticos, incluindo certos tipos de } \\
\text { tintas; evitar os agentes de limpeza odoríferos; número adequado de } \\
\text { purificadores de ar. }\end{array}$ \\
\hline Conforto térmico & $\begin{array}{l}\text { Capacidade de controlar a temperatura do ar, umidade e circulação do } \\
\text { ar para atender às necessidades pessoais. }\end{array}$ \\
\hline Privacidade & $\begin{array}{l}\text { Capacidade de controlar a vista exterior; capacidade de controlar a } \\
\text { interação social e a visão do doente na cama adjacente; local seguro } \\
\text { para os objetos pessoais (fotografias de família, cartões de votos de } \\
\text { melhoras, flores). }\end{array}$ \\
\hline Luz & $\begin{array}{l}\text { Luz e brilho no quarto do doente; capacidade de controlar a } \\
\text { intensidade da luz; luz adequada para leitura; janela deve estar } \\
\text { suficientemente baixa para o paciente ver o exterior enquanto está na } \\
\text { cama; a iluminação do quarto do paciente deverá ser de espectro } \\
\text { completo. }\end{array}$ \\
\hline Comunicação & $\begin{array}{l}\text { Capacidade de entrar em contato com a equipe quando necessário; } \\
\text { lugares confortáveis para visitar com a família; televisão, rádio e } \\
\text { telefone disponíveis quando necessários. }\end{array}$ \\
\hline Visões da natureza & $\begin{array}{l}\text { Visões de árvores, flores, montanhas ou de oceanos, a partir dos } \\
\text { quartos e os lugares de descanso dos doentes; paisagismo interior. }\end{array}$ \\
\hline Cores & $\begin{array}{l}\text { Uso cuidadoso da cor para criar disposição e espírito elevado. Tornar } \\
\text { quartos alegres. }\end{array}$ \\
\hline Textura & $\begin{array}{l}\text { Introdução de variedades de texturas nas superfícies das paredes, } \\
\text { chão, tetos, tecidos e obras de arte. }\end{array}$ \\
\hline $\begin{array}{l}\text { Acomodação para } \\
\text { familiares }\end{array}$ & $\begin{array}{l}\text { Proporcionar lugar para membros da família, para que estes se sintam } \\
\text { bem-vindos, em vez de intrusos; proporcionar lugares de descanso } \\
\text { para as visitas e acesso a máquinas de vendas de produtos, telefones e } \\
\text { cantina. }\end{array}$ \\
\hline
\end{tabular}

Fonte: Malkin (1992); Watson (2002a). 
Watson refere que a enfermagem ainda tem um longo caminho a percorrer para atender ao ambiente e às artes básicas de cura, conforme a tradição que Nightingale transmitiu.

\begin{abstract}
Futuramente, a enfermagem e outras profissões de saúde, que trabalham num hospital, deverão criar novos centros para cuidar-curar e necessitarão de estar envolvidas em pelo menos duas missões: criar espaços de cuidar-curar, do ponto de vista ambiental e transpessoal e; fazer parte de relações curativas, sistemas e comunidades (WATSON, 2002, p. 253-254).
\end{abstract}

O espaço de cura, proposto por Watson, torna-se um espaço sagrado e a doença transforma-se numa oportunidade para alguém se tornar mais consciente e ser mais autenticamente capaz, ao nível da energia humana. Neste novo espaço, é possível experienciar processos que ajudam a repadronizar e/ou potenciar o todo, a cura, o autoconhecimento, o autocontrole e as possibilidades de autocura (WATSON, 2002a).

As práticas do cuidar nesses ambientes de cura buscam cuidados que visam atender às necessidades espirituais dos pacientes; atendem a sentimentos, relações de ensinoaprendizagem, momentos de cuidar, consciência e ações concretas, principalmente relacionadas a um ambiente de suporte, protetor, ou mentalmente corretivo, físico, sociocultural e espiritual (WATSON, 2002a).

Observa-se que a rotina, a sobrecarga de trabalho, a ênfase nas questões biológicas do cuidado e a ausência de um ambiente adequado de cura encontrados no local da pesquisa reiteram as palavras de Watson (2002) ao afirmar que os sistemas de saúde, as instituições e a maneira que estão organizados os serviços de saúde e de enfermagem são incompatíveis com o cuidar integral. Nas palavras da autora, essa visão do sistema tradicional de saúde acaba por submergir os valores de cuidar e da enfermagem e ameaçam o conceito da função de cuidar do enfermeiro (WATSON, 2002).

\footnotetext{
Para satisfazer as demandas tecnológicas e burocráticas crescentes do sistema, o cuidar ao nível do indivíduo e do grupo tem recebido cada vez menos ênfase no sistema. Torna-se cada vez mais difícil à enfermagem manter sua ideologia do cuidar na prática (WATSON, 2002, p. 53-54).
}

As dificuldades desveladas na pesquisa tornam a enfermagem vulnerável, frágil. Apesar das grandes dificuldades apontadas, foi possível apreender que os enfermeiros mantêm dentro de si a vontade de cultivar um contato maior e uma aproximação maior com os pacientes. Entretanto, a realidade de trabalho suscita sentimentos de impotência, angústia e infelicidade. Os relatos a seguir demonstram a emergência desses sentimentos: 
Acaba que dentre os meus pacientes que talvez sejam os que mais precisam de uma atenção, de uma escuta qualificada, são os pacientes que estão internados há mais tempo e que acabam ficando com menos assistência. Isso porque eu já sei o quadro clínico deles e não posso ficar indo lá porque eu tenho paciente grave pra cuidar. Realmente é muito difícil (E1).

Não vou mentir pra você. Eu me canso espiritualmente. Fisicamente a gente já tira isso de letra porque faz parte. Se tiver que pegar peso a gente pega. Mas não ver o paciente de uma maneira integral parece que a espiritualidade da gente cansa, a alma sai (E10).

Aqui os pacientes são atendidos mais nas suas demandas físicas, de dor, medicamentos que tem que fazer. São realmente poucos os que a gente consegue sentar e fazer outros cuidados, voltados para essa questão psicológica, pra essa questão espiritual. Na verdade a gente tem oferecido pouco do básico. Isso me angustia (E12).

Parece que os enfermeiros da Clínica Médica estão suscetíveis ao que chamamos de Síndrome de Burnout. Essa síndrome resulta de um processo que envolve três dimensões: (a) exaustão emocional - desgaste ou perda de recursos emocionais que os levam à falta de entusiasmo, frustração e tensão; (b) uma despersonalização por meio do desenvolvimento de sentimentos e atitudes negativas no trabalho e; (c) a diminuição da realização pessoal no trabalho - tendem a ter uma avaliação profissional negativa, tornando-se infeliz, insatisfeito, originando sentimentos de inadequação e fracasso (GALINDO et al, 2012).

Ressalta-se que a essência da enfermagem é o cuidado; isso significa zelo, atenção; cuidar implica interação com outro. Porém, quando a rotina hospitalar afasta o enfermeiro do cuidado integral, como acontece com os profissionais deste estudo, o trabalho transforma-se em fonte de angústias e decepções, o que finda por influenciar uma cadeia de fatores que desvalorizam o trabalho de toda a categoria profissional. Assim, não se pode negligenciar o sofrimento dos profissionais que cuidam. Faz-se necessário romper a tendência de cuidar e se concentrar somente nos sintomas físicos, como se fosse a raiz única de angústias do paciente. Na relação do cuidado, o diálogo, a escuta, a sensibilidade, a ternura, a empatia são aspectos importantes que o enfermeiro precisa estar atento e que deve fazer parte da política e prática cotidiana do cuidar institucional (BESERRA et. al., 2014).

As dificuldades apontadas pelos enfermeiros - lacuna na formação, rotina estressante, a falta de ambiência de cuidado e a sobrecarga de trabalho - implicam negativamente no cuidado transpessoal e dificultam alguns tópicos do Clinical Caritas Process preconizado por Watson, tais como: estar autenticamente presente; desenvolvimento e permanência de uma autêntica relação de Cuidado; estar presente para apoiar a manifestação de sentimentos negativos e positivos; atender a outra pessoa integralmente e o sentido subjetivo da experiência; criação de um envolvimento saudável em todos os níveis, em que a totalidade, a 
beleza, o conforto, a dignidade e a paz sejam potencializados; manter a intencionalidade consciencial do Cuidado ao tocar e lidar com o espírito encarnado do outro, honrando a unidade do Ser e permitir a conexão espiritual.

\subsubsection{Os Fatores que Favorecem o Atendimento das Necessidades Espirituais do}

\section{Paciente}

Nessa categoria, os verbos escutar e ouvir, juntamente com as palavras oração, fé, tolerância, pensamento positivo, individualidade, protocolos e educação permanente e continuada permitiram deduzir que, apesar das dificuldades reveladas, os enfermeiros elencaram um conjunto de estratégias que podem ser adotadas para atender as necessidades espirituais de seus pacientes, dentre elas destacaram: a escuta qualificada e todos os sentimentos e atitudes que a favorecem, a implantação da SAE e educação permanente.

A escuta qualificada:

Acho que o ponto de partida para trabalhar a espiritualidade do paciente é a escuta qualificada (E1).

Pra mim trabalhar a espiritualidade do paciente é escutar o paciente, ouvir o que ele tem pra falar. Falar das suas queixas de dor, de medos, de sonhos na vida (E2).

A espiritualidade está muito ligada ao respeito ao próximo, depois saber ouvir e também dar tempo para a pessoa falar. O ouvir principalmente faz a diferença. Faz e muita diferença (E3).

Ouvir o paciente, o que a pessoa que tá ali tem a dizer. Às vezes ela clama alguma coisa pra gente. Se a gente conseguir, pelo menos, ouvir com atenção, a gente já tá ajudando (E9).

A fala dos enfermeiros alinha-se ao pensamento de Watson (2002a). Para a autora, a escuta qualificada é um dos principais recursos que o enfermeiro possui para garantir um cuidado individualizado e integral. A escuta qualificada gera processos de autoconhecimento, autorrespeito, autocura e autocuidado. Desta maneira ajuda as pessoas a ganharem um grau mais elevado de harmonia na mente, no corpo e na alma (WATSON, 2002a).

Se o enfermeiro for capaz de detectar a as necessidades espirituais do paciente por meio de uma escuta qualificada, o paciente será capaz de libertar os sentimentos pelos quais tem ansiado e tem desejado expressar; assim a subjetividade humana é restabelecida e mais fortemente acontece a experiência de cuidar (Watson, 2002a). A escuta qualificada unida ao toque, ao olho no olho e até mesmo ao silêncio são primordiais para a busca do cuidado integral (Polastrini; Yamashita; Kurashima, 2011). Nesse contexto, a escuta qualificada 
assume uma conformação capaz de mergulhar na espiritualidade e no modo que cada paciente manifesta seu sofrimento e suas angústias durante o processo de doença (MAYNART et al., 2014).

Os enfermeiros demonstraram sensibilidade ao elencar um conjunto de sentimentos que compõem uma escuta qualificada, sugerindo uma série de atitudes que favorecem o cuidado da dimensão espiritual. Entende-se que, para uma boa escuta qualificada, a empatia torna-se extremamente relevante. Essa empatia é a capacidade de se colocar no lugar do outro, de modo a sentir o que o outro sente, caso esteja em seu lugar (MIRANDA \& MIRANDA, 1996).

Além da empatia, sentimentos como a amorosidade e o otimismo são primordiais para qualificar a escuta. Esses sentimentos também foram verificados nos relatos dos enfermeiros: Quando eu falo de cuidado espiritual, o primeiro que vem na minha cabeça é
aprender a ouvir. Eu acho que é isso. Ouvir. Não falar de religião, mas falar de
maneira geral, do acolhimento, do amor, do respeito ao ser humano Não uma troca
de religião, mas uma troca de amor, de respeito, dos momentos doloridos que a
gente passa, a gente vai ter que reunir forças onde a gente tiver, para seguir a vida
(E3).

Seria bom se a gente tivesse tempo pra poder se sentar, ficar um tempo ali ouvindo, dialogando, e tentar motivar a busca da espiritualidade. Uma palavra de conforto que você já dá pro paciente, eu acredito que é muito positivo. Um conforto. Um incentivo (E5).

Eu vejo a positividade, o otimismo ajuda muito o paciente a se recuperar com mais rapidez. Você percebe que quando uma pessoa tem uma positividade, quando ela tem otimismo, não fica com pensamentos negativos, pensamentos pessimistas. A reabilitação e a recuperação é muito mais rápida (E10).

Exemplos de vida. Palavras de otimismo. Palavras de sabedoria. Momentos de leitura. Momentos que tragam a fé e fortaleçam a emoção (E10).

O otimismo e o amor são peças fundamentais para acessar o universo espiritual do paciente. Jean Watson (2008) relata que o Amor é o elemento essencial para que o Momento do Cuidado seja estabelecido na clínica. Essa busca do Amor no contexto do cuidado é, decididamente, uma construção espiritual. Outros aspectos levantados pelos enfermeiros e que também fazem parte da escuta qualificada foram o incentivo à fé, à tolerância e o respeito à religiosidade:

A espiritualidade pode ser acessada ao aceitá-la e respeitá-la. Além disso vem a tolerância e o respeito às religiões (E1).

A espiritualidade está no pensamento positivo, na energia positiva, na oração, na reza. Pra gente trabalhar a espiritualidade do paciente a gente tem que respeitar a questão cultural, religiosa, a forma de pensar de cada um. Eu como enfermeiro devo dar aquela palavra de conforto, sempre identificando a fé da pessoa e 
incentivando o paciente a pegar aquela fé pra enfrentar esse desafio, essa etapa que ele está passando (E4).

Tem gente que por si só tem mais fé, já é mais espiritualizado, mais tranquila, acredita que tudo vai dar certo. A gente observa que o paciente que é espiritualmente mais desenvolvido, com mais fé, ele é um paciente mais seguro, que confia mais nas coisas, que vai ficar bem (E12).

Ao respeitar e compreender as crenças e valores do ser humano, o enfermeiro entenderá como o paciente enfrenta a doença e o modo como esses valores influenciam na sua qualidade de vida. Além disso, o respeito às crenças contribuem ainda com uma melhor relação enfermeiro-paciente. Reconhecendo esses valores, o profissional poderá abordar a fé do doente de maneira adequada, sem ir de encontro à crença em que o paciente acredita, sem ferir sua individualidade (BATISTA, 2010).

Na perspectiva dos sujeitos, a implementação da SAE seria uma boa maneira para incluir a dimensão espiritual nos cuidados de enfermagem:

Poderia ter um protocolo de admissão e conversar com esse paciente, saber o que ele tá sentindo, o que ele espera do tratamento e ao longo desse tratamento ir conversando pra ver se ele está satisfeito, se está confiante, talvez algo nesse sentido (E12).

Deveriam implantar a SAE aqui com questões que abordassem a espiritualidade (E12).

O Conselho Federal de Enfermagem, em sua Resolução 358, de 2009, preconiza que o Processo de Enfermagem deve ser realizado, de modo deliberado e sistemático, em todos os ambientes, públicos ou privados, em que ocorre o cuidado profissional de Enfermagem. Este processo é organizado em cinco etapas inter-relacionadas, interdependentes e recorrentes: Coleta de Dados de Enfermagem (ou Histórico de Enfermagem), Diagnóstico de Enfermagem, Planejamento de Enfermagem, Implementação e Avaliação de Enfermagem (COFEN, 2009).

Vale ressaltar que, no momento da coleta de dados desta pesquisa, a SAE estava em processos de implantação na clínica médica. Entretanto, uma das entrevistadas chamou a minha atenção, mostrando que no protocolo a ser implementado os cuidados com a dimensão espiritual não estavam comtemplados, conforme relato a seguir:

Deixa eu ver aqui, pera um pouquinho, pra ver se na admissão a gente pergunta alguma coisa sobre a religião do paciente...Verificar...A gente tem um processo, um papel novo de admissão...Mas normalmente a admissão são orientações básicas...Diagnósticos, procedimentos, condições de alta, condições da morte, alta, transferência...Identificação...Data, idade, estado civil, local, cor, sexo...Parentesco...Nome do pai, da mãe...Profissão...Nada sobre religião ou espiritualidade do paciente (E12). 
Dessa forma, verifica-se que, apesar do empenho de renovação da rotina do trabalho por meio da implantação da SAE no setor, os cuidados espirituais não receberam ainda a devida atenção. Considerando-se que a clínica recebe pacientes em cuidados paliativos, esse aspecto é bastante preocupante.

Acrescenta-se que a North American Nursing Diagnostics Association (NANDA) aprovou, em sua nona conferência em 1990, uma definição ampla do diagnóstico de enfermagem entendido como um julgamento clínico sobre as respostas do indivíduo, da família ou da comunidade a problemas de saúde, processos vitais reais ou potenciais.

Na versão publicada da NANDA, em 2012, encontram-se diagnósticos referentes às necessidades espirituais/religiosas de pacientes, famílias e comunidades. São eles: Disposição para bem-estar espiritual aumentado, definido como a capacidade de experienciar e integrar significado e objetivo à vida por meio de uma conexão consigo mesmo, com os outros, com a arte, a música, a literatura, a natureza e/ou com um Ser maior, sendo que essa conexão pode ser aumentada (NANDA, 2012, p.312).

Sofrimento Espiritual refere-se à capacidade prejudicada de experienciar e integrar significado e objetivo à vida por meio de uma conexão consigo mesmo, com os outros, com a arte, a música, a literatura, a natureza e/ou um Ser maior (NANDA, 2012, p. 317).

Risco de Sofrimento Espiritual - diz-se sobre o risco de apresentar prejuízo em sua capacidade de experimentar e integrar significado e objetivo à vida por meio de uma conexão consigo mesmo, com os outros, com a arte, a música, a literatura, a natureza e/ou um Ser maior (NANDA, 2012, p. 319).

Disposição para religiosidade aumentada - cita a capacidade de aumentar a confiança em crenças religiosas e/ou de participar de ritos de uma fé religiosa em particular (NANDA, 2012, p. 324).

Religiosidade prejudicada - define-se como a capacidade prejudicada de confiar em crenças e/ou de participar de ritos de alguma fé religiosa (NANDA, 2012, p. 325).

E Risco de religiosidade prejudicada que diz que seria o risco de ter uma capacidade prejudicada de confiar em crenças religiosas e/ou de participar de ritos de alguma fé religiosa (NANDA, 2012, p. 326).

Além da presença dos diagnósticos de enfermagem sugeridos pela NANDA, vale ressaltar que diferentes instrumentos já foram criados e validados para avaliar as necessidades espirituais/religiosas de pacientes e que podem ser utilizados pelos enfermeiros na etapa de coleta de dados da Sistematização da Assistência de Enfermagem, tais como: Inventário 
Espiritual de Kuhn; História Espiritual de Mattews; Instrumento Espiritual FIIA; História Espiritual de Maugans; Questionário HOPE; História Espiritual do ACP (American College of Physician - Sociedade Americana de Médicos); Escala de Religiosidade de Duke DUREL; Escala de Coping Religioso-Espiritual - CRE; Brief Multidimensional Measure of Religiousness and Spirituality (BMMRS-p); Escala da Avaliação da Espiritualidade de Pinto e Pais-Ribeiro; Escala de Bem-Estar Espiritual; Escala de Atitude Religiosa Espiritual, dentre outras.

Ao incluir os instrumentos de coleta de dados e diagnósticos de enfermagem que contemplem a dimensão espiritual dos seus pacientes, os enfermeiros também podem prescrever cuidados individualizados que atendam às necessidades espirituais dos pacientes. Watson (2002a) cita as modalidades auditivas, visuais, olfativas, táteis, mental-cognitivas, cinestésicas, dentre outras, como cuidados transpessoais que podem ser prescritos pelos enfermeiros na sistematização da assistência de enfermagem (WATSON, 2002a).

A música e sons, denominadas por Watson como modalidades transpessoais auditivas, atuam como catalisadores para facilitar e aumentar as nossas capacidades interiores de cura e autocura; evocam fantasia, imaginação e mesmo transformação. A inclusão de música para meditação, com ruídos, sons calmantes de baleias, de água, por exemplo, libertam ou relaxam a consciência interior (WATSON, 2002a).

Outra prescrição de cuidados é a visualização. Nightingale viu a importância do estímulo visual interno e externo, da luz, da cor e da beleza como agentes efetivos do cuidar e da recuperação que eram integrais para a enfermagem. $O$ enfermeiro pode ensinar seus pacientes a usarem a visualização e as imagens como formas de autocontrole, autocuidado, autoconhecimento e autocura. É uma abordagem não invasiva, não intrusiva, autodirigida, autorregulada e não traz nenhum custo adicional, e apresenta um potencial para melhorar o quadro clínico do paciente. Essas práticas ajudam a acalmar, aliviam, relaxam e potencializam imagens de harmonia e a totalidade do ser (WATSON, 2002a).

Tanto Nightingale quanto Watson reconheceram o significado da modalidade olfativa. As associações de cheiros medicinais nos hospitais produzem emoção negativa e ansiedade (aromas desagradáveis aumentam a frequência cardíaca e respiratória, enquanto fragrâncias agradáveis diminuem a pressão arterial e frequência cardíaca). Assim, a aromaterapia, utilizada de maneira consciente e intencional, auxilia na função respiratória, nas abordagens meditativas e relaxantes. Estimula outros sentidos e evocam memórias involuntárias de experiências prévias; assim o enfermeiro deve encorajar pacientes e familiares a trazerem 
objetos de suas casas ou arredores - fronhas, lençóis, brinquedos, se possível. Tudo isso possibilita a diminuição do estresse da hospitalização (WATSON, 2002a).

O toque, como modalidade transpessoal tátil, também é fundamental para os cuidados de enfermagem. Pode ajudar a integrar e harmonizar, dar conforto, totalidade, integridade e mesmo um sentido de segurança. $\mathrm{O}$ uso intencional do toque, massagens e toque terapêutico são usados como parte das práticas holísticas e transpessoais. Algumas abordagens como Reiki e Shiatsu são terapêuticas baseadas na energia e usadas para diminuir a ansiedade, aliviar a dor e facilitar o processo de cura (WATSON, 2002a).

Dar ênfase na dieta, alimentos, texturas, aromas, aparência, atmosfera e ambiente são considerações pós-modernas. Personalizar os gostos e hábitos individuais pode fazer a diferença no cuidado transpessoal. O cuidar do corpo através da comida e sabores, com todas as associações e significados alimentares na vida do paciente, aumenta sua capacidade física e espiritual, o que também pode servir de prescrições de cuidados de enfermagem (WATSON, 2002a).

O uso intencional da modalidade mental-cognitiva pode ser traduzida como visualizações formais, imaginárias, terapia cognitiva, uso do humor, da brincadeira, da narrativa, da literatura, da poesia, da arte, de afirmações positivas, do diálogo e do ensino, podem auxiliar no cuidado transpessoal e auxiliar no silêncio, solidão e práticas contemplativas e meditativas (WATSON, 2002a).

A cinesiologia aplicada como a quiropraxia e o Reiki são consideradas modalidades cinestésicas. O uso de movimentos suaves e fluentes, a dança e o fluir rítmico estão sendo incorporados, de forma crescente, nas terapias e programas de terapia formal, também sendo consideradas transpessoais e que ajudam o paciente a acessar a sua espiritualidade (WATSON, 2002a).

O uso da modalidade da consciência de cuidar envolve o estar presente. Essa presença pode ser tanto física quanto psicológica ou terapêutica. A presença física refere-se ao "estar presente" para o outro; o estar fisicamente presente. A presença psicológica é o "estar com o outro"; envolve ligação mente-a-mente; é o estar disponível para o outro, ambos com uma relação de ajuda básica e utilizar competências de comunicação como escutar, empatia, consideração incondicional e aceitação sem julgar. A presença terapêutica está intimamente ligada com a consciência de cuidar, atenção, intencionalidade e cuidar transpessoal; envolve a meditação, intencionalidade, abertura, comunhão, o amar e a conexão. Este nível de presença pode ser traduzido em presença transpessoal (WATSON, 2002a). 
Educação permanente da equipe de enfermagem:

Ter uma pessoa experiente, uma pessoa que entenda, uma pessoa que saiba expor $e$ conversar e ir introduzindo esse tema de espiritualidade aqui. Eu acredito que possa dar certo. Eu acho que ter uma capacitação assim seria importante, até pra poder fortalecer a espiritualidade do profissional (E10).

Eu acho que educações continuadas poderiam abordar esse lado da espiritualidade. Fazer reuniões com a equipe pra falar sobre espiritualidade (E11).

Acho que poderia trazer pra cá quadros, situações, quadro de respostas dos pacientes, porque deve haver estudos sobre isso. Paciente fala assim, ele reage assim. E a partir disso a gente ter uma orientação pra nossa resposta, como fazer, como lidar com a situação (E12).

Seria bom ter orientações como lidar, como conversar, como você responder às situações que vão ocorrendo, referente à espiritualidade (E12).

A educação permanente é um processo educativo que ocorre no espaço do pensar e do fazer do trabalho (Ricaldoni \& Sena, 2006). Assim, a inclusão de estratégias educacionais no ambiente de trabalho e, em especial, a espiritualidade no cuidado do paciente poderá estimular os enfermeiros a buscarem mais estratégias e informações importantes para trazer para si a responsabilidade de atualização sobre o tema e abordar as necessidades espirituais de seus pacientes.

Isso acontece porque a educação permanente trata de um processo de reflexão, de mudanças e transformações. Nesse contexto, leva-se em consideração o serviço, o trabalho, o cuidado, a educação, a qualidade e a integralidade da assistência (RIBEIRO \& MOTA, 2007).

Assim, torna-se indispensável o desenvolvimento de programas educacionais, em especial no serviço, para a melhoria da qualidade e integralidade dos cuidados de enfermagem. Entretanto, algumas falas denotaram que para alguns a abordagem da espiritualidade do paciente deveria ser feita pela comunidade religiosa e líderes religiosos que visitam o hospital.

Deve-se respeitar a individualidade do paciente. Motivar o paciente a buscar a espiritualidade e buscar a fé. A forma dele orar, dele apegar, dele buscar a Deus e, se for possível, se tiver tempo, de repente, ter uma conversa coletiva, uma busca coletiva dessa espiritualidade com um religioso, da fé do paciente (E5).

Eu não consigo pensar como fazer isso. Acho que deveria vir uma equipe especializada nisso, em espiritualidade (E6).

Acho que o pessoal das igrejas que vem aqui está mais preparado pra isso. Como eu vou oferecer aquilo que não sei, que não fui treinada pra fazer? (E8).

É fato que a presença de religiosos e líderes espirituais podem auxiliar pacientes a conseguirem enfrentar melhor as adversidades provenientes de um processo de adoecimento. 
Guimarães \& Avezum (2007) afirmam que os enfermeiros têm transferido para essas pessoas a incumbência de lidar com as questões espirituais/religiosas dos pacientes, talvez por falta de clareza de como abordar as questões espirituais de seus pacientes devido a uma lacuna na formação, ou devido à sobrecarga de trabalho (ou os dois). Apesar de a enfermagem enfatizar a importância de reconhecer a religião e a espiritualidade como fontes para o enfrentamento de doenças, os enfermeiros ainda não conseguem incluí-los de maneira efetiva na sua prática clínica diária (GUIMARÃES; AVEZUM, 2007).

Os enfermeiros devem utilizar as atividades religiosas como adjuvantes ao tratamento, paralelamente aos cuidados diretos prestados ao paciente. Ações como cirurgias espirituais, meditação, cultos, missas e visitas religiosas podem ser incentivadas, a depender da crença do paciente (SPADACIO; BARROS, 2009).

Observou-se, portanto, que a assistência de enfermagem frente às necessidades espirituais dos pacientes ainda tem sido incipiente. Apesar de concordarem que a dimensão espiritual é uma dimensão importante do paciente internado, os enfermeiros ainda não se sentem preparados para cuidar dessa dimensão; ou por falta de preparo ou por motivos inerentes à rotina, à sobrecarga de trabalho e à ambiência desfavorável da Clínica Médica.

A seguir, serão apresentadas as vivências dos pacientes sobre suas necessidades espirituais.

\subsection{PERFIL DOS PACIENTES}

Participaram do estudo 06 pacientes, internados na Clínica Médica do Hospital Universitário de Brasília (HUB), no período compreendido entre os meses de julho e setembro de 2014. Desses pacientes, quatro (04) eram do sexo feminino (67\%) e dois (02), do sexo masculino (33\%) com idades entre 35 e 67 anos, tendo uma média de 47,7 anos.

Em relação ao diagnóstico clínico, 04 (quatro) pacientes apresentavam carcinoma de estômago, intestino ou cerebral (67\%); 01 (um), sem diagnóstico definido (16,5\%) e 01 (um) com neuropatia diabética e pé diabético $(16,5 \%)$.

Questionados se professavam alguma religião, 2 (33\%) consideravam-se católicos; 2 (17\%), cristãos, porém sem religião definida; 1 (17\%) se declarou evangélico e 1 (17\%), praticante da filosofia Seicho-No-Iê. A seguir apresenta-se o perfil dos pacientes de acordo com o sexo, idade, diagnóstico clínico e religião. 
Tabela 2 - Perfil dos pacientes que participaram da pesquisa quanto ao sexo, idade, diagnóstico clínico e religião. Brasília 2014.

\begin{tabular}{|c|c|c|c|c|}
\hline & Variáveis & $\begin{array}{c}\text { Mulheres } \\
n^{0}(\%)\end{array}$ & $\begin{array}{c}\text { Homens } \\
\mathbf{n}^{\mathbf{0}}(\%)\end{array}$ & $\begin{array}{c}\text { Total } \\
n^{0}\end{array}$ \\
\hline \multirow[t]{3}{*}{ Sexo } & & $4(67)$ & $2(33)$ & 6 \\
\hline & $35-40$ & $1(25)$ & - & 1 \\
\hline & $41-45$ & $1(25)$ & - & 1 \\
\hline \multirow[t]{5}{*}{ Idade } & $46-50$ & $1(25)$ & $2(100)$ & 3 \\
\hline & Acima de 50 & $1(25)$ & - & 1 \\
\hline & Total & $4(100)$ & $2(100)$ & 6 \\
\hline & Carcinoma & $4(100)$ & - & 4 \\
\hline & Sem diagnóstico & - & $1(50)$ & 1 \\
\hline Diagnóstico & Diabetes e suas & & & \\
\hline \multirow[t]{3}{*}{ Clínico } & Complicações & - & $1(50)$ & 1 \\
\hline & Total & $4(100)$ & $2(100)$ & 6 \\
\hline & Católica & $2(50)$ & - & 2 \\
\hline \multirow[t]{4}{*}{ Religião } & Cristão (s/religião) & - & $2(100)$ & 2 \\
\hline & Evangélico & $1(25)$ & - & 1 \\
\hline & Seicho-No-Iê & $1(25)$ & - & 1 \\
\hline & Total & $4(100)$ & $2(100)$ & 6 \\
\hline
\end{tabular}

Fonte: Dados da pesquisa.

A presença de um número elevado de pacientes com câncer nesta pesquisa reitera os dados apresentados pelo Instituto Nacional do Câncer (INCA) que estima para o Brasil, no ano de 2014, a ocorrência de aproximadamente 576 mil novos casos de câncer, reforçando a magnitude do problema do câncer no país (INCA, 2014).

Essa mesma pesquisa do INCA estima que no Distrito Federal, nos anos de 2014 e 2015, haverá uma maior incidência de câncer em mulheres (4230 casos) do que em homens (3.320). Também foi encontrado um número maior de mulheres com neoplasia na Clínica Médica.

Em relação à religião dos entrevistados, o resultado encontrado é semelhante aos dados apresentados no Censo Demográfico brasileiro de 2010, do Instituto Brasileiro de Geografia e Estatística (IBGE). O Censo demonstrou que a religião católica continua sendo a maior religião do país $(64,4 \%)$, embora haja uma maior diversidade religiosa da população brasileira (BRASIL, 2010).

Um dado interessante que também foi observado entre os enfermeiros é que, apesar de dois sujeitos declararem não possuir religião definida, ambos se consideravam cristãos. Em 
todos os depoimentos os pacientes afirmaram que a religiosidade/espiritualidade é um fator importante para o enfrentamento da doença e das dificuldades frente à internação.

\subsection{VIVÊNCIA DOS PACIENTES ACERCA DA DIMENSÃO ESPIRITUAL E DOS CUIDADOS DE ENFERMAGEM}

$\mathrm{Na}$ análise do conteúdo das entrevistas, emergiram dois eixos significativos. No primeiro eixo, denominado O Suporte Terreno, os pacientes mencionaram as bases de sustentação utilizadas por eles para o enfrentamento dos desafios causados pelo diagnóstico e tratamento da doença. Esse eixo foi composto por três categorias: A Travessia Pessoal, A Travessia com a Família e Outros Ajudantes na Travessia.

No segundo eixo, denominado O Suporte Divino, os pacientes relataram as buscas empreendidas no âmbito do Sagrado, do intangível, do impalpável durante o processo de adoecimento. Esse eixo foi composto por três categorias denominadas As Fontes do Sagrado, Os Enviados do Sagrado e, Deus - a fonte da fé. A primeira categoria revelou que a busca por uma religião para enfrentar a doença e as dificuldades da vida são importantes nesse processo; é através da religião que os pacientes encontram uma fonte eficaz de chegar mais próximo do Sagrado, do Divino.

A segunda categoria desvelou como os pacientes interpretam o papel dos profissionais de saúde: representantes do Divino na Terra para ajudá-los a recuperar a saúde. A terceira categoria revelou que, para os pacientes, Deus, o Divino, o Sagrado é a fonte de tudo; é na presença Dele que os pacientes bebem o néctar da fé e se fortalecem espiritualmente para enfrentar as adversidades da vida.

Foi possível apreender que o discurso dos pacientes centrou suas bases de sustentação no mundo ordinário e no mundo espiritual. Entretanto, observou-se que o segundo eixo teve uma maior importância para os pacientes. Enquanto o primeiro eixo (Suporte Terreno) representou $41 \%$ do discurso dos pacientes, o segundo eixo (Suporte Divino) representou 59\% desse discurso. Isso demonstra que o Suporte Divino tem sido extremamente relevante no enfrentamento da doença

Os dois eixos e suas respectivas categorias foram representados no dendograma a seguir. 


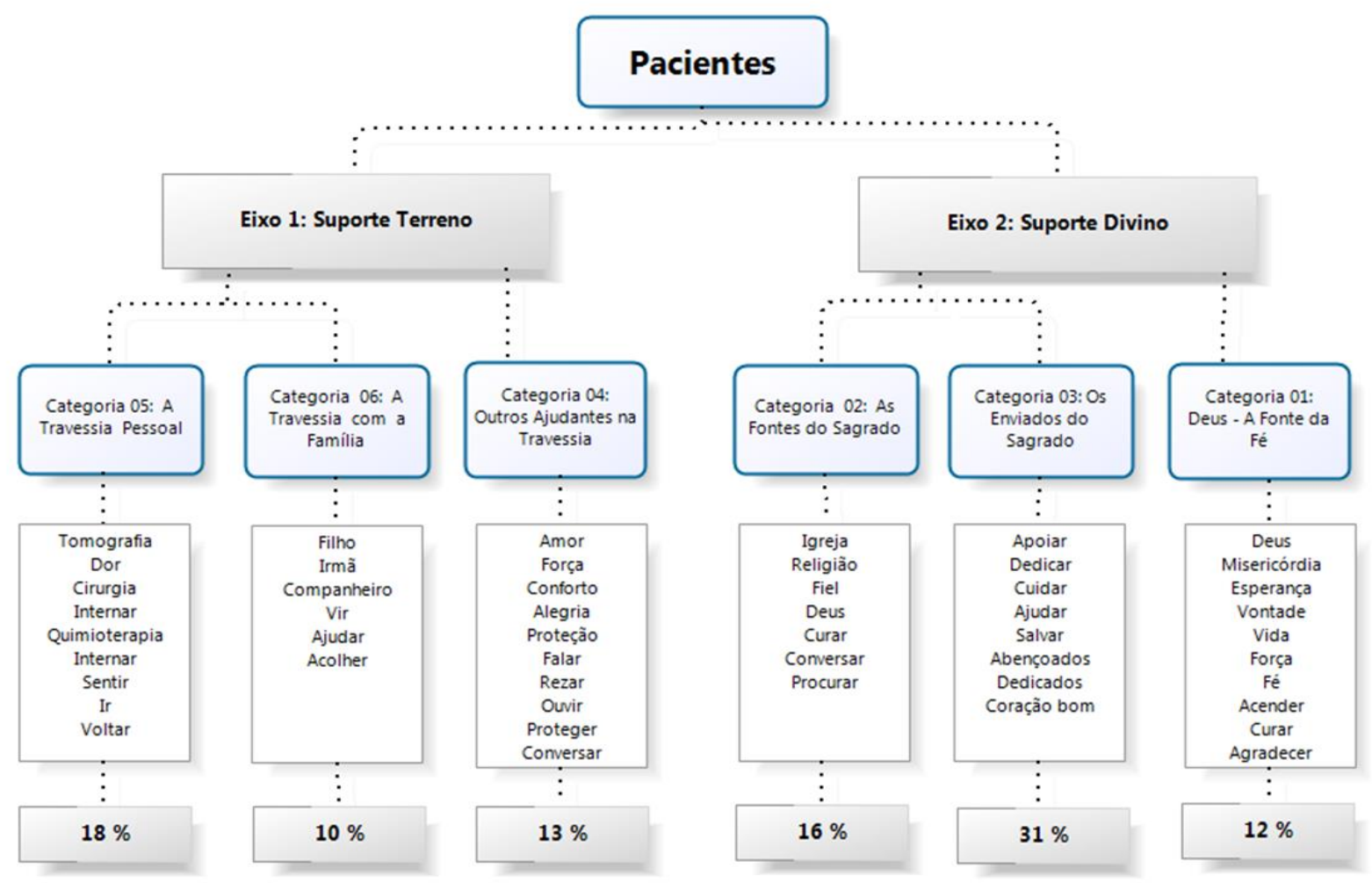

Figura 2: Dendograma com os eixos e categorias que emergiram da análise das entrevistas dos pacientes. Brasília, 2014.

Fonte: Dados da pesquisa.

\subsubsection{O Eixo do Suporte Terreno}

A análise do eixo desvelou que a rede de sustentação dos pacientes no enfrentamento da doença é constituída por um tripé formado por seus recursos pessoais, o apoio familiar e outras fontes de apoio (outros profissionais do hospital como equipe da limpeza, nutrição, psicologia, voluntários, religiosos dentre outros). O discurso dos pacientes tem a conotação do movimento empreendido para lidar com a nova situação, há frequente referência às idas e vindas que os mesmos fizeram frente ao processo de adoecimento-tratamento-cura.

$\mathrm{Na}$ primeira categoria, denominada A Travessia Pessoal, palavras como vim, começou, acabou, vou, volto, agora, fiz e vir dão essa ideia de movimento. Na segunda categoria, denominada A Travessia com a Família, verbos como ficar, chutar, ir, acompanhar denotam que na travessia pessoal eles foram acompanhados pelos familiares.

$\mathrm{Na}$ terceira categoria, denominada Outros Ajudantes na Travessia verbos como passar, vir, orar, falar evidenciaram as ajudas de outras pessoas (profissionais, voluntários, 
religiosos, etc.) que levam a fé e a esperança para o paciente enfrentar a doença durante o período de internação.

\title{
3.4.1.1 A Travessia Pessoal
}

Ao receberem o diagnóstico médico, os pacientes relataram a dificuldade encontrada frente ao diagnóstico. Palavras como tomografia, dor, cirurgia, quimioterapia e verbos como internar, sentir, ir e voltar fazem referência aos constantes desafios enfrentados no percurso desde o diagnóstico até o tratamento, elencando as dificuldades nessa travessia.

\begin{abstract}
Eu não sentia nada antes. Eu era uma mulher de ferro. Trabalhava dia e noite. E numa madrugada eu senti uma forte dor no estômago. Aí os médicos me consultaram, e na tomografia eles descobriram. A gente nunca está preparado pra uma notícia assim. No momento eu perdi o chão (Pl).
\end{abstract}

Eu vim pra cá semana passada. O meu problema foi esse no braço, esse sistema neurológico. E também o meu pé. Sou diabético e não sabia. Começou com essa ferida no pé. Começou arranhando e acabou tendo que amputar a cabeça do dedinho aqui. Deu gangrena. E aí tem um mês que tô nessa vida, sem trabalhar, sem nada, nessa sofrendo. Agora ainda vem esse problema de tremer (P4).

Tem quatro meses que vou e volto. Dessa vez eu já tô aqui tem três dias. Em vez de fazer as necessidades, eu tava inchando. Aí descobriram que era câncer de intestino. Fiz a cirurgia e agora eu tenho que vir pra cá pra fazer a quimioterapia pra tirar os resíduos e a bolsa de colostomia (P6).

O impacto no paciente frente ao diagnóstico de uma doença depende de aspectos peculiares de cada um, englobando a sua forma de ser e de estar frente ao mundo e a si mesmo (Graham et al, 2005). O diagnóstico médico de uma doença grave pode desencadear no paciente um conjunto de sentimentos e sensações, como ansiedade, medo e incerteza (MOLINA; 2005).

Nesse momento tão delicado, o enfermeiro deve manifestar elevada consideração e reverência à pessoa e à vida humana. Ele precisa se considerar como elemento coparticipante no processo de cuidar e ajudar o paciente na aquisição de maior conhecimento próprio, autocontrole e preparação para o autocuidado, independentemente da condição externa de saúde. Essa atitude permite que se desenvolva um elevado valor no relacionamento entre o enfermeiro e o paciente (WATSON, 2002).

É na expressão de sentimentos positivos durante o tratamento que se encontra a arte do cuidar transpessoal. É arte quando o enfermeiro, tendo experimentado ou percebido os sentimentos do outro, é capaz de detectá-los, senti-los e, por sua vez, de expressá-los de tal 
forma que a outra pessoa é capaz de conhecê-los mais profundamente e de liberar os sentimentos que busca expressar (WATSON, 2002).

Essa interação estabelecida no cuidar entre a confirmação do diagnóstico médico e a internação propicia uma aproximação e uma ligação da mente-corpo-alma do enfermeiro com a mente-corpo-alma do paciente; o momento partilhado desse encontro - denominado ocasião real do cuidar - tem o potencial para transcender o tempo, o espaço e o mundo físico concreto, preconizado por Watson em seu cuidado transpessoal (WATSON, 2002).

Dessa maneira, o enfermeiro pode ter acesso indiretamente à mente, às emoções e ao eu interior das pessoas, através de qualquer esfera - mente, corpo ou alma - desde que o corpo físico não seja entendido ou tratado separadamente da mente, das emoções e de um sentido mais elevado do eu - a alma (WATSON, 2002).

\subsubsection{A Travessia com a Família}

A segunda categoria deste eixo, denominada Travessia Familiar, demonstra que a família tem tido um papel fundamental de suporte para os pacientes para enfrentar os desafios advindos da doença. Palavras como filho, irmã, companheiro e os verbos vir, ajudar, acolher desvelam a importância do suporte fornecido pelo grupo familiar; demonstrando que nesse período de adoecimento/internação os pacientes não atravessam sozinho, pois têm a família do lado, conforme relatos a seguir.

Mas aí toda a família ficou ao redor, acolheu, todo mundo me tratou como uma princesa. Tanta gente, tanto carinho (P1).

Meu filho que me ajudou muito. Quando recebi a notícia da doença, ele pegou e falou assim...Mãe, tudo o que vier a você, pense que é uma bola num campo de futebol, mate no peito, deixe cair na grama. E essa bola quem te chutou foi Deus. Então chute e deixe fazer o gol (P2).

Eu tenho um companheiro que tem muita fé em Deus. Muitas vezes eu falava que não queria ir pra quimioterapia, mas era ele que me incentivava e me acompanhava. Ele tem muita fé em Deus, sabe. E foi por causa dele que me apeguei mais ainda em Deus pra vencer esse câncer, sabe (P6).

Percebe-se que a internação e a doença não são encaradas apenas pelo paciente, mas vista como uma ameaça vivenciada de maneira grupal, fazendo com que a família redefina seus papéis e modifique seus hábitos de vida. E essa presença familiar para o paciente traz segurança afetiva, tranquilidade e diminuição do estresse advindo da doença (SILVEIRA, 2004). 
Dessa maneira, a família do paciente acometido por uma doença grave torna-se a principal fonte de apoio para o paciente no momento inicial da doença (Wanderbroocke, 2005). Esse apoio permite estabilidade emocional para o paciente lutar contra as adversidades, suprir suas carências emocionais e alcançar uma melhor aceitação do diagnóstico e tratamento (Mistura et. al., 2011; Waidman, 2004). Desta maneira, a presença da família torna a travessia mais segura.

Nos relatos, observou-se que a família desempenhou três fatores que, para Watson (2002), são primordiais para a criação de uma relação de ajuda-confiança no processo de cuidar: coerência, empatia e calor humano não-possessivo. A coerência implica ser verdadeiro, honesto, genuíno e autêntico. A empatia envolve a capacidade de compreender as perspectivas e sentimentos do outro e transmitir essa compreensão. E o calor humano nãopossessivo demonstra uma postura aberta, afetiva, de acolhimento (Watson, 2002). Para a autora, essa relação de ajuda-confiança (encontrada entre pacientes-família da pesquisa) representa um dos princípios elementares para o cuidar transpessoal (WATSON, 2002).

Assim, a família desempenha um papel importante para transformar conceitos e comportamentos dos pacientes durante o período de adoecimento, tornando-se um sustentáculo emocional, físico, financeiro e espiritual para eles (Melo, Silva \& Fernandes, 2005; Corbellini, 2001). Esse suporte estimulou um ajuste saudável à nova condição do paciente, constituindo-se num componente essencial na sua travessia.

\subsubsection{Outros Ajudantes na Travessia}

Nessa terceira categoria, denominada Outros Ajudantes na Travessia emergiu a presença e a importância de outros atores que auxiliam na travessia entre o adoecer e a busca da cura. São eles voluntários, religiosos, ou mesmo outros profissionais que desempenham suas funções dentro do hospital como funcionários da limpeza, da nutrição, psicologia dentre outros. Essas pessoas suscitam conforto e fé por meio de ações complementares durante a internação e o tratamento. Palavras como amor, força, conforto, alegria, proteção, e os verbos falar, rezar, ouvir, proteger, conversar evidenciam o papel desses outros ajudantes que buscam satisfazer as necessidades dos pacientes em falar e conversar sobre religiosidade/espiritualidade. No discurso dos sujeitos, ratificou-se que os pacientes esperam que os profissionais de saúde toquem em temas sobre religião e espiritualidade. Isso corrobora a pesquisa de Koenig (2005) que diz que "muitos pacientes gostariam que os profissionais de saúde comentassem sobre suas necessidades espirituais” (KOENIG, 2005, p. 87). 
Às vezes aqui passam voluntárias pra ler uns trechinhos da Bíblia pra gente. Mas se a enfermagem lesse pra gente também seria muito bom. Quando falam de Deus, assim, pra gente, a gente sente mais amor, mais carinho, ajuda a gente a ficar mais forte, dá uma palavra mais fortificante. (P1)

Primeiro a gente sente quando a enfermeira traz alegria no olhar, no sorriso. A gente vê. É preciso que ela tenha muito tato de dirigir sua palavra de fé, no lugar em que a gente está e com quem ela está. E a gente quando tá doente está mais leve e mais aberta pra receber essa fé. (P2)

Acho muito importante que venham falar sobre a nossa fé. E quando alguém vem falar sobre isso com a gente, eu fico alegre, porque eu sei que a cada dia que passa, Deus, além de me proteger, está cuidando de mim. Foi uma tremenda alegria conversar com você porque tô precisando mesmo desabafar. Deus me mandou você pra vir conversar comigo. (P4)

A gente se sente muito pesada com essa doença, num quarto assim. Muitas vezes as pessoas vêm aqui, falam da quimioterapia, outras falam da doença, outra vem $e$ fura a gente, mas não fala de vida, de fé, de Deus pra gente. A palavra de Deus é um conforto, é um alívio na vida da gente, principalmente quando a gente está internada. Sabe por quê? Porque eleva os pensamentos da gente na nossa família, nos nossos filhos, na nossa mãe, nos nossos sonhos, na nossa vida. (P6)

Foi possível apreender nas falas dos pacientes um profundo respeito pelas manifestações de fé, derivadas das crenças religiosas. Desta forma, observa-se que este posicionamento traduz uma necessidade de abertura e atenção aos mistérios espirituais e dimensões existenciais da vida-morte, expressos no décimo elemento do Caritative Factors, defendido por Watson - reconhecimento da existência de forças fenomenológicasexistenciais-espirituais. A autora afirma que a manutenção da fé, o respeito à crença do semelhante e a cura da ferida da alma são elementos essenciais no ato de conectar-se com o outro (Watson, 2002). Concordo com Mathias (2007) quando diz que, sem qualquer menosprezo à ciência, a fé e a esperança aumentam a capacidade do ser para os diferentes enfrentamentos da vida.

O respeito à crença do paciente também se correlaciona com o que Watson comenta como campo fenomenológico, um dos principais conceitos de sua teoria. Para a autora, ao analisar o campo fenomenológico das experiências humanas na saúde e na doença, tais como pensamentos, sensações e crenças espirituais, o enfermeiro terá dados necessários para entender a condição humana e, consequentemente, buscar estratégias para atender às necessidades espirituais dos seus pacientes (WATSON, 2002).

Observa-se que o discurso dos pacientes ratifica que, no período de adoecimento e internação, a crença religiosa se une à racionalidade da medicina moderna; essa união é vista pelos pacientes como uma maneira de se encontrar a paz e solucionar seus problemas. Isso reitera as palavras de Watson, quando ela diz que sua teoria transpessoal não rejeita a ciência, 
mas lhe presta homenagem e constrói, com base nela, para poder expandi-la (WATSON, 2002).

Nessa linha argumentativa, outros autores citam o respeito às crenças espirituais e religiosas como fonte de suporte do paciente. Sendo assim, Martins (2008) verificou que o Sagrado tem um grande potencial vinculado à recuperação de pacientes; quando eles se deparam com o sofrimento e doença, eles claramente podem buscar apoio na religião (MARTINS, 2008).

Para as pessoas que seguem uma religião, muitas das doutrinas ou ensinamentos de sua fé oferecem orientação moral e prática com relação a como promover, conservar ou recuperar a saúde ou o bem-estar físico e emocional. Além das regras presentes nos ensinamentos religiosos, a consideração do corpo humano como sagrado, frequentemente presente nas mesmas, leva o crente a valorizar os cuidados de saúde (VASCONCELOS, 2010).

Justiniano (2003) afirma que, ao esculpir a realidade mediada pelo pensamento religioso, o paciente encara a doença e busca explicações para ela transpondo a ciência; neste sentido a crença religiosa passa a ter um papel de resignação na vida da pessoa doente, contribuindo para a construção de pensamentos positivos relacionados à doença e ao tratamento.

$\mathrm{O}$ apoio à crença religiosa e o incentivo à prática espiritual fortalecem a conexão com o Sagrado. Nesse sentido, o paciente sente-se acolhido pela proteção de um Ser superior que o acompanha e o ajuda a enfrentar os obstáculos da doença (KAOUPA et. al., 2007; SILVA; ACKER, 2007).

Também foi verificado por Kubler-Ross (2005), Boff (2006) e Vasconcelos (2006) que diante da doença é notável o apelo à religião por parte de pacientes e familiares, através de promessas e orações que servem como fonte de esperança na sobrevivência do doente e como forma de suportar a situação. Watson (2002) ressalta que a enfermagem deve adotar um novo paradigma, transformador do cuidar-curar, superando a medicalização da saúde e das experiências humanas e incluir a espiritualização da saúde e a cura interior (WATSON, 2002).

Concorda-se com Watson (2002) quando ela afirma que o agente de mudança na condição de saúde do paciente não é o médico, nem o enfermeiro, nem a medicação, nem o tratamento ou a tecnologia em si, mas os mecanismos pessoais, mentais-espirituais interiores da pessoa que lhe permitem ser curada através de vários meios, internos ou externos; e a fé se enquadra neste aspecto. 
Entretanto, observou-se que os pacientes parecem compreender praticamente total ausência de uma abordagem religiosa e espiritual por parte da equipe de enfermagem, e afirmam que, quando essa abordagem está presente, ela ainda é incipiente e eles demandam por ela. Queixam-se da abordagem voltada apenas para as questões biológicas.

Eu sei que vocês estão muito ocupados com os afazeres, ou são poucos enfermeiros
e que não sobra tempo pra isso, falar sobre Deus. Mas assim, me desculpe, também
falta preparação. Nem todos estão preparados. Porque na verdade é uma coisa
muito séria. Vocês não podem chegar e falar da espiritualidade sem estar
preparadas pra isso (P2).

Aqui no hospital tem um padre que veio me visitar duas vezes. A gente se sente bem, que Jesus tá nos protegendo. Algumas enfermeiras falam de Deus, mas poucas (P5).

Em momento algum, do tempo que eu estou aqui, as meninas da Enfermagem nunca falaram de Deus comigo, nunca. Às vezes chega aqui pra oferecer uma revista pra passar o tempo, mas não é assim. Se são médicos, enfermeiros, têm que chegar e conversar comigo...Saber o que estou sentindo, se eu converso com Deus, igual o senhor tá fazendo aqui comigo agora. Não só chegar aqui e perguntar se estou bem, que dia vou ter alta, que dia se internou. Ou falar que eu tô boa, tô ótima, se dormi bem (P6).

Comparando o discurso dos enfermeiros com as demandas dos pacientes, é possível dizer que os enfermeiros estão perdendo a essência humana do processo de cuidar. Se o papel da enfermagem á atender as necessidades dos pacientes, pode-se inferir que os enfermeiros estão fechando o coração e não conseguem olhar para além da técnica.

Contudo, devido à sua vulnerabilidade frente à finitude da vida, devido à dependência de outros e aos impactos advindos da doença, o paciente abre o coração, seus canais de percepção e sua mente para novas possibilidades; busca trilhar um novo caminho - uma travessia do mundo dos doentes para o mundo dos sadios. Assim, os seus canais de percepção da espiritualidade se tornam mais sensíveis, buscando um contato maior com o Sagrado, com o Divino. Isso é claramente comprovado quando se observa uma maior representatividade do segundo eixo (59\%) durante o processo adoecimento-internação-tratamento-cura.

Assim, enquanto os enfermeiros se fecham para os cuidados espirituais, os pacientes se sentem mais suscetíveis a eles.

Esses dados ratificam o pensamento de Watson (2002), que comenta que os modelos convencionais de cura têm sido eficazes na eliminação ou reparação das doenças do corpofísico, baseados em forças e intervenções externas, mas não têm conseguido curar ao nível transpessoal, interior, profundo, atingindo a dimensão espiritual (WATSON, 2002).

Embora a maioria dos enfermeiros reconheça que os pacientes possuem uma dimensão espiritual, poucos realmente identificam problemas espirituais ou procedem a intervenções 
espirituais. Isso pode ser resultado de restrições econômicas, quadro de pessoal precário e cuidados de alta tecnologia, que forçam os enfermeiros a se concentrarem nas necessidades biológicas (CAVENDISH et al, 2003; WILKINKSON \& VAN LEUVEN, 2010).

Watson (2002) defende, entre os dez Caritative Factors, princípios elementares da prática de Enfermagem, o Cultivo da Sensibilidade em Si e no Outro, isto é, habitar a condição humana significa basicamente Sentir e envolve relacionamento com os outros, consigo, com a natureza, com Deus ou um Poder Superior. Esta habilidade é desenvolvida a partir dos estados emocionais e determina a intensidade do envolvimento do profissional nas relações de cuidado (PENHA, 2012).

\subsubsection{O eixo do Suporte Divino}

\subsubsection{As Fontes do Sagrado}

No discurso dos pacientes, as palavras igreja, religião, fiel, Deus e os verbos curar, conversar, procurar evidenciaram a necessidade de os pacientes em apoiar-se em uma religião ou mesmo buscarem uma congregação religiosa que os auxiliem nessa travessia da doença para a cura. Essa busca pela religião torna-se uma maneira efetiva de ligar-se ao Sagrado. Isso pode ser demonstrado nos relatos a seguir.

Todos os caminhos nos levam a Deus. Todas as religiões são escolas do espírito, da alma. Então isso é muito importante pra gente, porque numa hora dessa que a gente recebe um diagnóstico de que você está com câncer, é uma pancada na cabeça. E foi na minha conversa com Deus, peguei os livros da minha igreja, comecei a ler e, conversando com Deus, vi que não estava sozinha. Por isso nessa minha luta diária, a minha ida à igreja me fortifica, sem essa busca na igreja a gente fica frágil (P2).

Deus vai tocar no meu coração pra eu procurar uma religião. Eu quero seguir. Eu quero ser fiel a Deus. Na hora que eu tiver bom e puder calçar um sapato, por uma roupa, pisar no chão...Aí com fé em Deus eu vou procurar uma religião pra mim e agradecer (P4).

Quando eu entrei no hospital eu achava que não ia ficar nem um mês. Mas a minha fé, de Deus e das correntes de oração da minha igreja me ajudaram. Muita gente da minha igreja pediu por mim e eu creio que foi isso que me deu força pra eu estar bem até aqui (P5).

Watson (2002) afirma que os profissionais de saúde têm estado tão divididos na percepção do físico-material versus espírito-não-físico, que apenas agora começaram a se preocupar com as necessidades da alma (Watson, 2002). E a religião tem se tornado cada vez mais um instrumento de explicações que ajudam a dar significado ao processo saúde-doença, 
suporte emocional e social, além de motivação e recursos adicionais ao cuidado em saúde. O reconhecimento dessas crenças pelos profissionais de saúde tornam o paciente e seus familiares mais dispostos a receber o tratamento proposto (LEE; NEWBERG, 2005).

Os recursos de suporte encontrados nas diferentes religiões ajudam a confortar pacientes e famílias nas experiências inesperadas de doença e morte trazendo consequências positivas como uma forma de crescimento, resignação, regeneração ou de evolução (BOUSSO, 2011).

Ao incentivar a expressão religiosa dos pacientes, os enfermeiros incluem cuidados básicos essenciais, como a ligação corpo-alma. Isso faz com que se reconsidere a importância do cuidar-curar por meio de ações não invasivas, não intrusas, modalidades naturalmente curativas (WATSON, 2002).

Assim cabe ao enfermeiro auxiliar os pacientes a exercerem sua fé na religião ou através das experiências que favorecem suas crenças, princípios e convicções. Não se pode impor, alterar ou influenciar estes pontos de vista; a fé, como vista anteriormente, deve ser respeitada, pois cada um acredita naquilo que é verdade para si, a fim de alcançar o seu equilíbrio e bem-estar (RODRIGUES GOMES, 2011).

Quase todas as religiões ditam comportamentos com relação à saúde, à doença e à morte. Para as pessoas que seguem uma crença religiosa/espiritual, muitas das doutrinas ou ensinamentos de sua fé oferecem orientação moral e prática com relação a como promover, conservar ou recuperar a saúde ou o bem-estar físico e emocional (VASCONCELOS, 2010).

O efeito da devoção religiosa para o bem-estar subjetivo supera qualquer benefício que se possa atribuir ao tipo de afiliação religiosa ou à frequência de participação religiosa institucionalizada. Koenig et al. (1988) constataram que professar frequentemente uma religião está associada com disposição de ânimo superior, com menor agitação, solidão e insatisfação com a vida. Associou-se também com uma capacidade maior para lidar com a tensão (VASCONCELOS, 2010).

Ao se estudarem as diversas religiões contemporâneas, observou-se que todas as grandes tradições religiosas têm teorias sobre o sofrimento, criando contextos explicativos que geram sentidos e desenvolvendo estratégias de lidar com situações de desesperança. $\mathrm{O}$ modo como se define o sofrimento e como ele é entendido e remediado muda de uma religião para outra. Mas todas elas procuram desenvolver esperança naqueles que adotam seus ensinamentos (VASCONCELOS, 2010). 
Assim, para um paciente fragilizado, pertencer a um grupo religioso pode ser um fator importante de sobrevivência e de solução de problemas para os quais a sociedade não responde (ALVES; JUNGES; LÓPEZ, 2010).

\subsubsection{Enviados do Sagrado}

Nesta categoria, verbos como apoiar, dedicar, cuidar, ajudar, salvar bem como palavras como abençoados, dedicados, coração bom permitiram dizer que, apesar de os pacientes não terem tido oportunidades de discutir sobre religiosidade/espiritualidade com os profissionais de saúde, eles os veem como enviados do Sagrado para cuidar deles e curá-los. Os relatos a seguir demonstram essa confiança que os pacientes transferem aos seus cuidadores:

Eu tive muita sorte com esse hospital aqui. Fui muito abençoada por todos que me apoiam aqui, por todos que me carregam, sabe. Aqui sinto esse aconchego maior de poder falar sobre mim, sobre Deus (Pl).

Muito obrigado, maravilhosos médicos, muito obrigado, maravilhosos enfermeiro, enfermeira, faxineiro, cozinheiro, cozinheira, ajudante de cozinha e a todos que estão me servindo. Eles não têm a menor obrigação. Estão cuidado de mim com todo amor, como se eu fosse alguém da família deles. Dinheiro nessa hora não importa, não importa o quanto você ganha. Sinto que estão servindo de coração. Isso pra mim é o que importa. O que eu quero mais é que todos sejam muito felizes. Porque você sendo feliz você tem muito mais felicidade pra me dar e eu vou poder dar pra vocês. Vocês estão trabalhando aqui pra tirar o outro do sofrimento e eu tenho que agradecer. Vocês são envidados por Deus (P2).

Eu queria que vocês continuassem assim como vocês são, tendo um coração bom pra ajudar quem precisa. Peço que uma pessoa nunca faça uma coisa, um favor pra outro com o coração fechado, com maldade. Que venha ajudar e cuidar da gente com o coração aberto, não com má vontade. Se não puder cuidar da gente com carinho, chama outro, mas não faça de má vontade (P3).

Ao observar o dendograma desse eixo, verificou-se que esta categoria possui uma elevada importância para os pacientes, pois representou mais da metade do percentual atribuído ao eixo. Nesse sentido, talvez os enfermeiros ainda não se deram conta da importância que eles têm para os pacientes.

A necessidade de estar presente é fundamental para que essa relação se fortaleça e as necessidades espirituais dos pacientes sejam atendidas. Não adianta os enfermeiros delegarem essa função apenas aos voluntários e religiosos que visitam o hospital; o estar presente do enfermeiro é primordial, pois são considerados pelos pacientes como enviados do Sagrado, do Divino. 
Assim, o papel dos profissionais de saúde precisa ir além dos cuidados; deve incluir o emocional e o espiritual. O trabalho emocional é um processo pelo qual os profissionais, e em especial os enfermeiros, conseguem regular as suas emoções, gerindo-as de uma forma saudável para cuidar da pessoa holisticamente (WATSON, 2006).

Vilelas (2013) ressalta a importância de os profissionais compreenderem e interpretarem as necessidades físicas das pessoas, responderem às suas necessidades emocionais, ou seja, gerir as próprias emoções, para melhor compreendê-las. E este olhar além das necessidades biológicas gera sentimentos de fé, amor e gratidão por parte dos pacientes. Por sua vez, conseguem acessar as necessidades espirituais.

Os enfermeiros, vistos como "enviados" do Sagrado, corroboram com o que Watson (2002) define como Processo Real de Cuidar. Para a autora, se a ocasião de cuidar é transpessoal, permitirá a presença do espírito do enfermeiro e do paciente; isso faz com que amplie e expanda a espiritualidade de ambos e se desenvolvam as potencialidades humanas (WATSON, 2002).

O profissional de enfermagem difere do paciente ou de um amigo, uma vez que ajuda a integrar a experiência subjetiva e as emoções, com uma visão objetiva externa da situação. O envolvimento pessoal, num espaço profissional, não é uma alternativa para outros tipos de envolvimento. É uma síntese de envolvimento, a participação de todo o eu, usando toda a dimensão da pessoa como uma fonte no relacionamento profissional (WATSON, 2002).

Watson defende que esta consciência de cuidar, de energia e de conexão, de um para o outro, tem um potencial de curar. $\mathrm{O}$ enfermeiro adepto ao cuidado transpessoal entende que o cuidar é, sobretudo, um modo de ser; aquele que cuida tem pensamentos de alta frequência e a consciência de cuidar. Esta frequência mais elevada da consciência de cuidar, por sua vez, ajuda a tranquilizar, a acalmar ou a potenciar o todo de uma pessoa com um sistema de baixa frequência - o que frequentemente é o caso se alguém está doente ou em sofrimento (WATSON, 2002a).

Além de modular a frequência da consciência do cuidar, o enfermeiro precisa estar presente no ato de cuidar. Watson (2002a) destaca três níveis de presença. O primeiro nível é a presença física - "estar presente" para o outro; isso implica verdadeiro contato corpo-corpo; envolve o toque, o abraço. O segundo nível é a presença psicológica - é o "estar com o outro"; é a ligação mente-mente; inclui uma intenção consciente para estar disponível para o outro; envolve a escuta ativa, a congruência, a consideração incondicional e a aceitação sem julgar. E o terceiro nível é a presença terapêutica - intimamente alinhada com a consciência de cuidar, atenção, intencionalidade e cuidar transpessoal; incorpora a intencionalidade, a 
abertura, a comunhão, o amar e a conexão. Este nível de presença e o estar presente deste “enviado do Sagrado" pode ser traduzido em presença transpessoal (WATSON, 2002a).

\subsubsection{Deus - a fonte da fé}

A terceira categoria deste eixo, denominada Deus - a fonte da fé, demonstra claramente a ligação que os pacientes possuem com o Sagrado. Palavras como Deus, misericórdia, esperança, vontade, vida, força, fé, e os verbos acender, curar, e agradecer, reforçam a fé e a esperança que os pacientes depositam no Sagrado para alcançarem a cura e a reabilitação. Isso pode ser visto nos relatos a seguir:

Quando Deus se manifesta realiza-se o bem, a justiça, a misericórdia. Não existe ninguém e nada que impeça o caminho de Deus. Sou grata Deus por tudo. Não peço pra Ele me curar, apenas que faça a Sua vontade (P2).

Depois dessa minha doença, minha fé tá dobrada. Eu tô sozinho, mas sei que Deus tá me protegendo como se eu tivesse em casa. Ele que não me deixou cair. É a fé em Deus em primeiro lugar (P4).

Deus na minha vida é muito importante. Deus foi quem me curou. E agora eu sei que ele não vai me deixar (choro). Tenho a imagem Dele bem grandona no meu quarto. Toda vez que eu olho pra Ele eu vejo a luz vindo em cima de mim. Sei que é através Dele que eu vou ser curada (P6).

Ao discutir o significado de "fé", Costa (2013) afirma que é um dom divino que, acolhido pelo homem, envolve todo o seu ser e promove a entrega incondicional e obediente àquele que é a fonte de salvação. No âmbito da Psicologia, Amatuzzi (2003) define a fé como aquilo que efetivamente anima a vida de uma pessoa ou lhe dá um sentido; numa visão antropológica, a fé é uma relação com o fim visado e que dinamiza todo o processo de ir em direção a ele; seria a determinação que dá toda energia ao agir (SEGUNDO, 1997).

Watson (2002a), ao discutir os sistemas de valores preconizados na teoria do cuidado transpessoal, demonstrou um profundo respeito pela fé das pessoas; ela reconhece a existência do Sagrado ou de um Poder Superior e sua influência no processo de cuidar e crescimento interior. Porém, a ciência ocidental, a psicologia e mesmo a enfermagem têm lidado de forma incipiente com o lado espiritual do homem (WATSON, 2002a).

Reiterando as ideias de Watson, Trentini et al. (2005) relatam que uma das formas de enfrentamento da doença está no sentimento de fé em Deus. Para os autores, a fé é um sentimento arraigado na cultura brasileira e torna-se tão necessária no processo de adoecimento-cura quanto o tratamento medicamentoso (TRENTINI et al., 2005). 
A fé em Deus também já foi descrita na literatura como uma necessidade de auxílio espiritual para melhor enfrentamento do medo, da solidão e do inesperado. Essa luta pela cura sustenta a esperança no dia a dia; a fé aumenta com a descoberta da doença e a confiança em Deus torna-se uma defesa aos sentimentos de temor e angústia da doença, assim, essa confiança em Deus pode ser percebida como uma forma de defesa aos sentimentos de temor e angústia (SALES; MOLINA, 2004).

Tudo isso corrobora o pensamento de Watson (2002), a qual preconiza, entre seus princípios elementares da prática de Enfermagem, o Cultivo da Sensibilidade em Si e no Outro. Para a autora, o cuidar envolve o relacionamento com os outros, consigo, com a Natureza, com Deus ou um Poder Superior (WATSON, 2002).

Enfermeiros cientistas e práticos devem apreciar alguns dos resultados não
esperados e não lineares e evitar preconceitos baseados em ideias enraizadas.
Devemos afastar-nos da homogeneidade de pensamento e procurar novas formas de
ver o habitual. (WATSON, 2002, p.18)

Ao incluir o Sagrado na prática de enfermagem, Watson (2002) considera que isso é uma das maneiras de dar "novas lentes para ver a enfermagem" (WATSON, 2002). 


\section{CONCLUSÃO}

O presente estudo buscou analisar as vivências de enfermeiros e pacientes frente à dimensão religiosa/espiritual nos cuidados de enfermagem com vistas a sua integralidade.

Os resultados da vivência dos enfermeiros frente ao cuidado da dimensão espiritual possibilitaram identificar fatores importantes que dificultam a prestação de cuidados espirituais no cotidiano de trabalho, tais como: lacuna na formação destes profissionais em relação à assistência de enfermagem voltada às necessidades espirituais; a sobrecarga e rotina estressante da Clínica Médica, bem como a falta de ambiência que propicie uma assistência de enfermagem voltada aos cuidados espirituais.

A lacuna nos currículos das instituições formadoras dos profissionais favorece que o cuidado da dimensão espiritual seja interpretado como menos importante, quando comparada aos cuidados físicos; e esse tipo de formação contraria as bases da teoria transpessoal de Jean Watson.

Buscar novas formas de ensinar e discutir a espiritualidade no âmbito dos cuidados integrais de enfermagem deve ser incentivado no Projeto Político Pedagógico dos cursos de formação profissional. Isso pode ser realizado pela inserção de disciplinas obrigatórias ou optativas no curso de graduação em enfermagem; ou por meio de discussões transversais nas diversas disciplinas do curso de enfermagem; ou mesmo através de estratégias de pesquisa e extensão que incluam a espiritualidade no âmbito do cuidado de enfermagem.

É importante que as instituições formadoras e promotoras do cuidado rompam com a lógica capitalista de organização de serviços e formação profissional. É preciso considerar a complexidade da natureza humana, incluir as discussões filosófico-espirituais no plano de cuidado de enfermagem e resgatar a essência desse cuidado.

Outro resultado importante foi que apesar de os profissionais entenderem o que significa integralidade no âmbito dos cuidados de enfermagem, o privilégio ao olhar biologicista dos cuidados se soma no cotidiano à sobrecarga de trabalho e à falta de ambiência adequada para o cuidado. Essas questões se mesclam e findam por desfavorecer um cuidado que integre a satisfação das necessidades espirituais do paciente. Os profissionais ainda se ressentem dessas condições na assistência e afirmam: "a espiritualidade da gente cansa, a alma sai”, e quando a alma de alguém abandona o corpo eles se tornam robóticos, de gestos repetitivos e acríticos, significando que o verdadeiro sentido de cuidar foi abandonado. 
Devido o contexto desfavorável da prática de cuidado dos enfermeiros não foi possível identificar as estratégias utilizadas para o manejo das necessidades espirituais dos pacientes. Entretanto, devido a esse mesmo contexto pode-se inferir que o mecanismo de negação seja frequentemente utilizado por esses profissionais.

Em relação à dimensão espiritual dos pacientes, ficou evidente que durante o período de adoecimento-internação-tratamento-cura eles buscam apoio em dois suportes distintos: um terreno e outro divino. O suporte terreno está voltado ao reforço pessoal para o enfrentamento da doença-tratamento; o suporte familiar ratifica a importância do apoio do núcleo familiar no enfrentamento dos desafios advindos da doença; e a presença de outros ajudantes demostram que ações complementares que suscitem conforto e fé no processo da internação e tratamento são fundamentais. Sendo assim, valoriza-se o papel de outros profissionais, voluntários e religiosos que visitam o hospital.

O suporte divino encontra-se alicerçado na congregação espiritual/religião, elo efetivo referido pelos pacientes de religação ao Sagrado; na confiança nos profissionais de saúde, percebidos como "enviados do Sagrado" para auxiliá-los na recuperação-cura, e em Deus, em quem os pacientes reforçam a sua fé e a esperança depositadas no Sagrado para alcançarem a cura e a reabilitação.

Ao entender a espiritualidade como uma busca de significado, de um propósito de vida, como a vivência de sentimentos como amor, conexão, paz interior, conforto e suporte, como a maneira que a pessoa manifesta externamente suas crenças espirituais, pode-se dizer que os resultados reafirmam que o ser humano é multidimensional e demonstra que, para cuidar da dimensão espiritual e integralmente, o enfermeiro deve compreender o que está para além do biológico e de questões religiosas.

Essa multidimensionalidade da espiritualidade deve ser privilegiada na prática cotidiana de enfermagem por meio de prescrições de cuidados que permitam atender às necessidades espirituais do paciente que fortaleçam o suporte terreno (escutas qualificadas com paciente, incentivo da presença da família durante a internação, proporcionar visita de outros profissionais e voluntários que possam trazer conforto e fé) e o suporte divino (incentivar práticas religiosas, o estar presente do enfermeiro respeitando as crenças de cada um e o seu modo particular de manifestar a sua fé em Deus). Sem dar o devido valor a todos esses aspectos apontados pela pesquisa, as necessidades espirituais dos pacientes podem não ser atendidas.

Em relação à religiosidade, parte integrante da espiritualidade, reforça-se que é necessário respeitar a religião de cada um, mas isso deve ir além. Não se pode adotar apenas 
uma atitude de imparcialidade e respeito em relação às crenças religiosas do paciente. Em outras palavras, um respeito sem envolvimento. Além disso, não se deve delegar essa função de atendimento das necessidades espirituais dos pacientes apenas para líderes religiosos ou voluntários de diversos grupos religiosos que esporadicamente frequentam a unidade de Clínica Médica. Ficou evidente no discurso dos pacientes que eles esperam uma palavra, um apoio espiritual, um estar presente dos profissionais de enfermagem durante o período de internação. Esta pesquisa deixou claro que os pacientes querem falar e discutir sobre sua espiritualidade com os profissionais de saúde.

Também se verificou nesta pesquisa que, durante o processo de adoecimentointernação-tratamento-cura, paciente e família como unidade de cuidado estão interligados. Isso demonstra que a presença do familiar durante o período de internação pode trazer benefícios para o paciente. Porém, observa-se que apenas crianças, adolescentes, gestantes e idosos têm garantidos, por lei, presença de uma acompanhante durante a internação. Talvez fosse interessante repensar a garantia de acompanhantes apenas para esses pacientes e expandir essa autorização para todos os pacientes. Não olhar apenas o impacto gerencial e econômico que a presença desses familiares teriam dentro do hospital, mas observar o papel que eles poderiam exercer no fortalecimento da espiritualidade dos pacientes, na humanização do cuidado e, consequentemente, na integralidade da assistência.

Com este estudo, sugere-se uma discussão aprofundada sobre a realidade das alas de internação da Clínica Médica do Hospital Universitário de Brasília; uma divisão do setor entre Clínica Médica e Clínica Oncológica pode ser o ponto de partida para minimizar os problemas de sobrecarga de trabalho, rotina desgastante e um novo redimensionamento de pessoal de enfermagem. Além disso, favoreceria a inclusão de um protocolo de cuidados paliativos no atendimento às necessidades espirituais dos pacientes ali internados sem possibilidades terapêuticas de cura.

Outra sugestão seria a promoção de ambientes de cura, nos moldes sugeridos por Jean Watson, para que a Clínica Médica pudesse ser a precursora no atendimento aos cuidados espirituais dos pacientes do Hospital Universitário de Brasília.

Apesar de desenvolvida numa realidade específica, os resultados da pesquisa sinalizam que a prática do cuidado espiritual por parte da equipe de enfermagem deve ser incluída desde a formação profissional. Novas estratégias de ensino que incluam a espiritualidade devem ser buscadas para suprir essa lacuna na enfermagem brasileira.

A enfermagem precisa se mover para além do objetivável, do cientificismo, da preocupação extenuante com a técnica. É o momento de o enfermeiro se dedicar às verdades 
ocultas, desenvolver novos conhecimentos que fomentem a discussão da dimensão espiritual e sua importância no âmbito do cuidado integral de enfermagem; significa buscar uma nova maneira de cuidar do outro numa sociedade que se recusa a valorizar esse cuidar. 


\section{REFERÊNCIAS}

ALBRECHT, P.A.T. KRAWULSKI, E. Concurseiros e a busca por um emprego estável: reflexões sobre os motivos de ingresso no serviço público. Cadernos de Psicologia Social do Trabalho. v.14, n. 2, p. 211-226, 2011.

ALVES, J. S. JUNGES, J. R. LÓPEZ, L. C. A dimensão religiosa dos usuários na prática do atendimento à saúde: percepção dos profissionais da saúde. O Mundo da Saúde, São Paulo. v. 34, n. 2, p. 430-436, 2010.

AMATUZZI, M. M. Fé e ideologia na compreensão psicológica da pessoa. Psicol. Reflex. Crit., Porto Alegre, v. 16, n. 3, p. 569-575, 2003.

ARAÚJO, D. F. BARBOSA, M.H. ZUFFI, F. B. LEMOS, R. C. A. Cuidados paliativos: percepção dos enfermeiros do hospital das clinicas de Uberaba-MG. Cienc. Cuid. Saúde. v. 9, n. 4, p. 690-696, 2010.

BATISTA, P.P.S. A valorização da espiritualidade nas práticas de educação popular em saúde desenvolvidas na atenção básica. Rev Eletrônica Comun Inf Inov Saúde. v. 4, n. 3, p. 94$102,2010$.

BALZER-RILEY, J. Comunicação em Enfermagem. Portugal: Lusodidacta, 2004. 480p.

BESERRA, E, P. et al. Sofrimento humano e cuidado de enfermagem: múltiplas visões. Esc. Anna Nery, Rio de Janeiro, v. 18, n. 1, 2014.

BOFF, L. Espiritualidade: um caminho de transformação. Rio de Janeiro: Sextante. 2006.

BORGES, M.S. O campo de cuidar: uma abordagem quântica e transpessoal do cuidado de enfermagem. Cienc. Cuid. Saúde. v. 12, n. 3, p. 606-611, jul/set. 2013.

BORGES, M.S. SANTOS, D.S. O campo de cuidar: uma abordagem quântica e transpessoal do cuidado de enfermagem. Cien.Cuid.Saúde. v. 12, n. 3, p. 606-611, 2013.

BOUSSO, R, S. Crenças religiosas, doença e morte: perspectiva da família na experiência de doença. Rev. esc. enferm. USP, São Paulo, v. 45, n. 2, p. 397-403, abr. 2011.

BRASIL. Ministério do Planejamento, Orçamento e Gestão. Instituto Brasileiro de Geografia e Estatística. Censo 2010. Disponível em: http://censo2010.ibge.gov.br. Acesso em jan. 2015.

CAPALBO, C. Considerações sobre o Método Fenomenológico e a Enfermagem. Rev. Enferm. UERJ. v. 2, n. 2, p. 192-197, 1994.

CARVALHO, C.S.U. Necessária atenção à família do paciente oncológico. Rev Bras Cancerol. v. 54, n. 1, p. 87-96, 2008.

CAVENDISH, R., KONECNY, L., MITZELIOTIS, C., RUSSO, D., LUISE, B., LANZA, M. et al. (2003). Spiritual care activities of nurses using Nursing Interventions Classification (NIC) labels, [Versão eletrônica] International Journal of Nursing Terminologies and 
Classifications, v. 14, n. 4. Acesso em 04 de janeiro de 2013. Disponível em: http://www.ncbi.nlm.nih.gov/pubmed/14768127.

COLLIÈRE, M. Cuidar: a primeira arte da vida. Lusociência: Portugal, 2003.

CONSELHO FEDERAL DE ENFERMAGEM (COFEN). Resolução n. 293, de 21 de Setembro de 2004. Fixa e Estabelece Parâmetros para o Dimensionamento do Quadro de Profissionais de Enfermagem nas Unidades Assistenciais das Instituições de Saúde e Assemelhados [legislação na Internet]. Rio de Janeiro; 2004. Disponível em: http://www.cofen.gov.br/resoluo-cofen-2932004_4329.html.

Resolução n. 358, de 15 de

Outubro de 2009. Dispõe sobre a Sistematização da Assistência de Enfermagem e a implementação do Processo de Enfermagem em ambientes, públicos ou privados, em que ocorre o cuidado profissional de Enfermagem, e dá outras providências [legislação na Internet]. Brasília; 2009. Disponível em: http://www.cofen.gov.br/resoluo-cofen3582009_4384.html

CORBELLINI, V. L. Câncer de mama: encontro solitário com o temor do desconhecido. Revista Gaúcha de Enfermagem, Porto Alegre, v. 22, n 1, p. 42-68, jan. 2001.

COSCRATO, G. Concepções de graduandos de enfermagem sobre humanização e espiritualidade: uma pesquisa-ação (tese). Ribeirão Preto: São Paulo; 2013.

COSTA, V. S. A fé como porta da salvação. Revista de Cultura Teológica. n. 81, p. 11-29, jan/jul 2013.

DAL-FARRA, R.A. GEREMIA, C. Educação em Saúde e Espiritualidade: proposições metodológicas. Rev.Bras.Ed.Médica. v. 34, n. 4, p. 587-597, 2010.

DOSSEY, L. Body - Mind - Spirit: Attending to Holistic Care. American Journal of Nursing. v. 98, n. 2, p. 35-38, 1998.

DYSON, J.C.M. The meaning of spirituality: a literature review. J Adv Nurs. v. 26, n. 6, p. 1183-1188, 1997.

FERNANDES, J, D, et al . Diretrizes curriculares e estratégias para implantação de uma nova proposta pedagógica. Rev. esc. enferm. USP, São Paulo, v. 39, n. 4, dez. 2005.

FERREIRA, A. B. H. Novo Dicionário da Língua Portuguesa. 2. ed. Rio de Janeiro: Nova Fronteira, 1988. $1838 \mathrm{p}$.

FERRISS, A.L. Religion and the quality of life. Journal of Happiness Studies. v. 3, n. 3, p. 199-215, 2002.

FRACOLLI, L.A.; ZOBOLI, E.L.P; GRANJA, G.F.; ERMEL, R.C. Conceito e prática da integralidade na Atenção Básica: a percepção das enfermeiras. Rev Esc Enferm USP, v. 45, n. 5, p. 1135-1141, 2011. 
FUNDAÇÃO INSTITUTO OSWALDO CRUZ (FIOCRUZ). Perfil da Enfermagem no Brasil. Rio de Janeiro, 2015. Disponível em: http://portal.fiocruz.br. Acesso em: mai. 2015.

GALINDO, R.H. FELICIANO, K. V. O. LIMA, R. A. S. SOUZA, A. L. Síndrome de burnout entre enfermeiros de um hospital geral da cidade do Recife. Rev Esc Enferm USP. v. 46, n. 2, p. 420-427, 2012.

GELCBKE, F.L.; REIBNITZ, K.L., PRADO, M.L.; LIMA, M.M.; KLOH, D. A práxis da enfermeira e a integralidade no cuidado. Enfermagem em Foco. v. 2, n. 2, p. 116-119, 2011.

GOMES, I.M; SILVA, D.I; LACERDA, M.R; MAZZA, V.A; MEIER, M.J; MERCES, N.N.A. Teoria do cuidado transpessoal de Jean Watson no cuidado domiciliar de enfermagem a criança: uma reflexão. Esc. Anna Nery, v. 17, n. 3, p. 555-561, ago. 2013.

GOMES, A.M.A; PAIVA, E.S; VALDÉS, M.T.M; FROTA, M.A; ALBUQUERQUE, C.M. Fenomenologia, humanização e promoção da saúde: uma proposta de articulação. Saúde soc. v. 17, n. 1, p. 143-152, 2008.

GRAHAM, I. W. et al. Mutual suffering: A nurse's story of caring for the living as they are dying. International Journal of Nursing Practice, n.1, p. 277-285, 2005.

GUIMARÃES H.P, AVEZUM A. O impacto da espiritualidade na saúde física. Rev. Psiquiatr. Clín. v. 34, n. 1, p. 88-94, 2007.

HUFFORD, David J. An Analysis of the Field of Spirituality, Religion and Health (S/RH). Disponível em: http://www.metanexus.net/tarp, 2005.

INSTITUTO NACIONAL DO CÂNCER (INCA). Estimativa 2014: incidência de câncer no Brasil. Rio de Janeiro, 2014. Disponível em: http://www.inca.gov.br/estimativa/2014. Acesso em fev. 2015.

JUSTINIANO, B. Religião ameniza dia-a-dia de portadores do vírus HIV. São Paulo (SP): Atheneu, 2003.

KAOPUA, L.S.I. GOTAY, C.C. BOEHM, P, S. Spiritually Based Resources in Adaptation to Long-Term Prostate Cancer Survival: Perspectives of Elderly Wives. Health \& Social Work, v. 32, n. 1, p. 29-39, 2007.

KOENIG, H, G. Religião, espiritualidade e psiquiatria: uma nova era na atenção à saúde mental. Rev. Psiquiatr. Clín. v. 34, n. 1, p. 5-7, 2007.

H.G. Medicina e saúde: o encontro da ciência e da espiritualidade. Porto Alegre, RS: L\&PM, 2012.248p.

, H.G. Espiritualidade no cuidado com o paciente: por quê, como, quando, o quê. FE Editora Jornalística, São Paulo, 2005: 140p.

H.G. Religion and Medicine II: religion, mental health and related behaviors. Int J Psychiatry Med. v. 31, n.1, p. 97-109, 2001a. 
H.G. McCULLOUGH, LARSON, D.B. Handbook of Religion and Health. New

York: Oxford University Press, 2001, 531p.

KOENIG, J.; KVALE, N.; FERREL, C. Religion and well-being in later life. The gerontologist, v.38, p.21-37, 1988.

KUBLER-ROSS, E. Viver até dizer adeus. São Paulo: Pensamento. 2005.

LEE, B. Y. NEWBERG, A. B. Religion and health: a review and critical analysis. Zygon. v. 40, n. 2, p. 443-468, 2005.

LEVIN, J.S. How religion influences morbidity and health: reflections on natural history, salutogenesis and host resistance. Social Science \& Medicine. v. 43, n. 5, p. 849-864, 1996.

LINARD, A.G. CASTRO, M.M, CRUZ, A.K.L. Integralidade da assistência na compreensão dos profissionais da Estratégia Saúde da Família. Rev Gaúcha Enferm. Porto Alegre, v. 32, n. 3, p. 546-553, set. 2011.

LUCCHETTI, G. GRANERO, A. L. BASSI, R. M. LATORRACA, R. NACIF, S. A. P. Espiritualidade na prática clínica: o que o clínico deve saber? Rev Bras Clin Med. v.8, n.2, p. 154-158, 2010.

MALKIN, J. Hospital interior architectrure? Creating healing environments for special patient populations. Van Nostrand Reinhold, Nova York, 1992.

MARTINS, L. Religião e Saúde: um estudo sobre as representações do fiel carismático sobre o processo de recuperação de enfermidades nos grupos de oração da RCC em Maringá (dissertação). Universidade Estadual de Maringá, 2008.

MATHIAS, J.J.S. Cuidado transpessoal de enfermagem ao familiar cuidador da criança com neoplasia: um marco referencial. (dissertação). Universidade Federal do Paraná, 2007.

MATTOS, R.A.; PINHEIRO, R (ORG). Os sentidos da integralidade na atenção e no cuidado à saúde. $8^{\text {a }}$ Edição. CEPESC - IMS/UERJ - ABRASCO: Rio de Janeiro, 2009.

MATTOS, R, A. A integralidade na prática (ou sobre a prática da integralidade). Cad. Saúde Pública, Rio de Janeiro, v. 20, n. 5, Out. 2004.

MAYNART, W, H, C, et al . A escuta qualificada e o acolhimento na atenção psicossocial. Acta paul. enferm., São Paulo, v. 27, n. 4, ago. 2014.

MCEWEN, M. \& WILLS, E.M. Bases teóricas para Enfermagem. Porto Alegre. Artmed, 2009.

McSHERRY, W., CASH, K. The Language of Spirituality: an emerging taxonomy. Int J Nurs Stud. v. 1, n. 3, p.1-11, 2003.

McSHERRY, W., JAMIESON, S. An online survey of nurses' perceptions of spirituality and spiritual care. J Clin Nurs. v. 20, n. 11-12, p. 1757-1767, 2011. 
MELO, E. M.; SILVA, R. M; FERNANDES, A. F. C. O relacionamento familiar após a mastectomia; Um enfoque no modo de interdependência de Roy. Revista brasileira de cancerologia, p. 219-225, 2005.

MINAYO, M.C.S. O desafio do conhecimento: pesquisa qualitativa em saúde. $10^{\mathrm{a}}$ ed. Rio de Janeiro: Hucitec; 2007.

MIRANDA, C.F; MIRANDA, M.L. Construindo a Relação de Ajuda. $10^{\text {a }}$ Ed. Belo Horizonte: Crescer, 1996.

MISTURA, C,. CARVALHO, M,F,A,A,. SANTOS, V, E, P. Mulheres mastectomizadas: vivências frente ao câncer de mama. R Enferm UFSM. v. 1, n. 3, p. 351-359, 2011.

MOLINA, M, A, S. Enfrentando o câncer em família (dissertação). Universidade estadual de Maringá, 2005.

MOREIRA-ALMEIDA, A., STROPPA, A. Espiritualidade e saúde: o que as evidências mostram. Revista Debates em Psiquiatria. v. 2, n. 6, p. 34-41, nov/dez. 2012.

MORIN, E. O método: o conhecimento do conhecimento. $2^{\text {a }}$ ed. Porto Alegre: Sulina; 2002.

North American Nursing Diagnosis Association. Diagnósticos de enfermagem da NANDA: definições e classificação 2012-2014. Porto Alegre: Artmed; 2012.

NEWMAN, M. Prevailing paradigms in nursing. Nursing Outlook. v. 40, n. 1, p. 10-13, 1992.

OMS (Organização Mundial de Saúde). The World Health Organization Quality of Life assessment (WHOQOL): position paper from the World Health Organization. Soc Sci Med. v. 41, n.10, p. 1403-1409,1995.

PARSES, R. Man-Living-Health: a theory of nursing. Wiley, Nova York. 1981.

PEDRÃO, R.B.; BEREZIN, R. O enfermeiro frente à questão da espiritualidade. Einstein. v. 8, n . 1, p. 86-91, 2010.

PENHA, R. M. A Espiritualidade na Teoria do Cuidado Transpessoal de Jean Watson: Análise de Conceito (tese). Universidade de São Paulo, 2012.

PERES, J, F, P., SIMÃO, M, J, P,. NASELlO, A, G. Espiritualidade, religiosidade e psicoterapia. Rev. Psiquiatr. Clín. v. 34, n. 1, p. 136-145, 2007.

PESSOA, S, M, F,. PAGLIUCA, L, M, F,. DAMASCENO, M, M, C. Teoria do cuidado humano: análise crítica e possibilidades de aplicação a mulheres com diabetes gestacional. Rev Enferm UERJ. v. 14, n. 3, p. 463-469, 2006.

POLASTRINI, R, T, V,. YAMASHITA, C, C,. KURASHIMA, A, Y,. Enfermagem e o Cuidado Paliativo. In: Santos FS (Org). Cuidados paliativos: Diretrizes, Humanização e Alívio de Sintomas. São Paulo: Atheneu; 2011. p. 277-283. 
RIBEIRO, A.S.M. Os homossexuais em busca de visibilidade social (tese). Universidade de Brasília, 2005.

RIBEIRO, E. C, O.; MOTTA, J. I. J. Educação permanente como estratégia na reorganização dos serviços de saúde. Universidade Federal da Bahia, 2007.

RICALDONI, C. A. C.; SENA, R. R. Educação permanente: uma ferramenta para pensar e agir no trabalho de enfermagem. Rev. Latino-Am. Enfermagem, Ribeirão Preto, v. 14, n. 6, nov/dez. 2006.

RODRIGUES GOMES, A. M. A espiritualidade no aproximar da morte. Enferm. glob., Murcia, v. 10, n. 22, abr. 2011.

ROGERS, M. A Theoretical Basis Of Nursing. FA Davis. Philadelphia, 1970.

ROHR, F. Espiritualidade e Formação Humana. Rev. Progr. Pós-Graduação em Educação - POIÉSIS. UNISUL, Tubarão, Número Especial: Biopolítica, Educação e Filosofia, p. 5368, 2011.

ROSS, L. Spiritual care in nursing: an overview of the research to date. J Clin Nurs. v. 15, n. 7, p. 852-862, 2006.

SALES, C, A,. MOLINA, M, A, S. O significado do câncer no cotidiano de mulheres em tratamento quimioterápico. Rev Bras Enferm, v. 57, n. 6, p. 720-723, 2004.

SANTOS, I.; CALDAS, C.P.;ERDMANN, A.L.; GAUTHIER, J.; FIGUEIREDO, N.M.A.; Cuidar da integralidade do ser: perspectiva estética/sociopoética de avanço no domínio da enfermagem. Rev. Enferm. UERJ, Rio de Janeiro, v. 20, n. 1, p. 9-14, jan/mar. 2012.

SEGUNDO, J. L. A história perdida e recuperada de Jesus de Nazaré: Dos sinóticos a Paulo. São Paulo: Paulus. 1997.

SHELLY, J. A., FISH, S. Spiritual Care: the nurse's role. $3^{\text {a }}$ Edição. Downers Grove, IL: Intervarsity Press, 1988.

SILVA, J.V. Jose Vitor da Silva, Cristine Giffoni Braga (org). Teoria de Enfermagem - 1 ed. - São Paulo: Iatria, 2011. Cap. 10 (226-46).

SILVA, C, A, M,. ACKER, J, I, B, V.O cuidado paliativo domiciliar sob a ótica de familiares responsáveis pela pessoa portadora de neoplasia. Rev Bras Enferm. v. 60, n. 2, p. 150-154, 2007.

SILVA, M.C.S; VALENTE, G.S.C; BITENCOURT, G.R; BRITO, L.N. A teoria do cuidado transpessoal na enfermagem: análise segundo Meleis. Cogitare Enferm. v. 15, n. 3, p. 548$551,2010$.

SILVEIRA, E.A.A. Compreendendo os sentimentos do visitante do cliente internado com Aids (tese). Escola de Enfermagem de Ribeirão Preto, Universidade de São Paulo; 2004. 
SOUZA, J.R.; MAFTUM, M.A; BAIS, D.D.H. Nursing care facing the recognition of patients' belief or religion: undergraduates' perceptions. Online Brazilian Journal of Nursing. v. 7, n. 2, 2008.

SPADACIO, C,. BARROS, N, F. Terapêuticas convencionais e não convencionais no tratamento do câncer: os sentidos das práticas religiosas. Interface comun saúde educ. v. 13, n. 30, p. 45-52, jul/set. 2009.

TAYLOR, C. LILLIS, C. LeMONE, P. Fundamental of Nursing: the art and science of nursing care. $6^{\text {a }}$ ed. Philadelphia: Lippincott Williams \& Wilkins, 2008.

TEIXEIRA, E. et al. Panorama dos cursos de Graduação em Enfermagem no Brasil na década das Diretrizes Curriculares Nacionais. Rev. bras. enferm., Brasília, v. 66, n. spe, p. 102110, Set. 2013.

TOMEY A.M, ALLIGOOD M.R. Teóricas de Enfermagem e sua obra: modelos e teorias de enfermagem. $5^{\text {a }}$ edição. Portugal: Lusociência, 2004.

TRENTINI, M,. SILVA, S, H,. VALLE, M, L., HAMMERSCHMIDT, K, S, A. Enfrentamento de situações adversas e favoráveis por pessoas idosas em condições crônicas de saúde. Rev Latino-am Enfermagem, v. 13, n. 1, p. 38-45, 2005.

TRIVIÑOS, A.N.S., Introdução à pesquisa em ciências sociais: a pesquisa qualitativa em educação, São Paulo: Atlas, 1992.

VASCONCELOS, E. M (Org.). Espiritualidade no trabalho em saúde. São Paulo: Hucitec, 2006.

VASCONCELOS, E. M. A associação entre a vida religiosa e saúde: uma breve revisão de estudos quantitativos. R. Eletr. de Com. Inf. Inv. Saúde. v.4, n.2, p.12-18, set. 2010.

VILELAS, J. O trabalho emocional no ato de cuidar em enfermagem: uma revisão do conceito. Revista de Ciências da Saúde da ESSCVP. v.5, p. 41-50, mar. 2013.

WAIDMAN, M, A, P,. ELSEN, I. Família e necessidades...revendo estudos. Acta Scientiarum Health Sciences. v. 26, n. 1, p. 147-157, 2004.

WANDERBROOCKE, A, C, N, S. Cuidando de um familiar com câncer. Taking care of a family member with cancer. Rev Psicol Argumento. v. 23, n. 41, p. 17-23, 2005.

WATSON, J. Caring as the essence and Science of Nursing and health care. O Mundo da Saúde, v. 33, n. 2, p. 143-149, 2009.

J. The Philosophy and Science of Caring - Revised \& Updated Edition. Boulder. University Press of Colorado, 2008.

, J. Can an ethic of caring be maintained? Journal of Advanced Nursing, v. 54, n. 3, p. 257-259, 2006. 
J. Enfermagem pós-moderna e futura: um novo paradigma da enfermagem. Tradução de João Enes. Portugal: Lusociência, 2002a. Título original: Postmodern nursing and beyond, 1999.

J. Enfermagem: ciência humana e cuidar - uma teoria de enfermagem. Tradução de João Enes. Portugal: Lusociência, 2002. Título original: Nursing: human science and human care - a theory of nursing, 1985.

WILKINSON, J.M. VAN LEUVEN, K. Fundamentos de Enfermagem: teoria, conceitos e aplicações. São Paulo: Editora Roca-Brasil, 2010. 


\section{Apêndice 1 - Termo de Consentimento Livre e Esclarecido (enfermeiros)}

UNIVERSIDADE DE BRASÍLIA

FACULDADE DE CIÊNCIAS DA SAÚDE

PROGRAMA DE PÓS-GRADUÇÃO EM ENFERMAGEM

Você está sendo convidado(a) a participar de um projeto de pesquisa que visa compreender a percepção dos enfermeiros sobre o papel da espiritualidade na integralidade do cuidado de enfermagem.

Tal projeto visa, principalmente, conhecer como os enfermeiros avaliam e interpretam as necessidades espirituais dos pacientes, compreender como os enfermeiros vivenciam a integralidade do cuidado e conhecer a percepção dos pacientes sobre os cuidados de enfermagem em relação ao atendimento de suas necessidades espirituais.

Como instrumentos de coleta, aplicaremos uma entrevista semiestruturada. No período da coleta dos dados, o pesquisador observará a atuação da equipe de enfermagem e sua relação interpessoal com os pacientes. Manteremos a sua identidade em segredo e não será possível identificar a sua resposta na análise dos dados ou quando esses forem publicados, uma vez que será dado tratamento genérico.

Este projeto foi aprovado pelo Comitê de Ética da Faculdade de Ciências da Saúde, sob o parecer $\mathrm{n}^{\mathrm{o}} 714.467$ de 09/07/2014, e nos comprometemos a desenvolver a pesquisa tal como foi aprovada. Ainda assim, você pode se retirar dela, mesmo após ter dado o seu consentimento, bastando para isto comunicar a um dos pesquisadores. Os dados serão publicados na forma de artigos científicos, comunicações ou painéis em eventos ou revistas científicas, independente de quais forem os resultados.

Para que você possa participar desta pesquisa, é necessário que assine as duas vias deste termo, retendo consigo uma cópia. E, caso deseje mais informações sobre a pesquisa ou mesmo fazer alguma denúncia, reclamação ou sugestão, por favor, entre em contato com o pesquisador responsável, Roberto Nascimento de Albuquerque, pelo número (61) 93025894 - celular, 32733807 (telefone do Departamento de Enfermagem ou ainda no Comitê de Ética da Faculdade de Ciências da Saúde (61) 31071947.

Caso você se sinta motivado e queira participar desta pesquisa, pedimos que assine abaixo, no espaço destinado ao sujeito da pesquisa, para que possamos usar as informações que você venha a nos fornecer.

Os gastos necessários para sua participação na pesquisa serão assumidos pelos pesquisadores. Fica também garantida a indenização em caso de danos, comprovadamente decorrentes da participação na pesquisa, conforme decisão judicial ou extrajudicial.

Brasília, I 


\section{Apêndice 2 - Termo de Consentimento Livre e Esclarecido (pacientes)}

UNIVERSIDADE DE BRASÍLIA

Você está sendo convidado(a) a participar de um projeto de pesquisa que visa compreender a percepção dos enfermeiros sobre o papel da espiritualidade nos cuidados de enfermagem.

Tal projeto visa, principalmente, compreender como os enfermeiros avaliam e interpretam as necessidades espirituais dos pacientes, compreender se os enfermeiros cuidam dos seus pacientes de maneira integral e conhecer a percepção dos pacientes sobre os cuidados de enfermagem em relação ao atendimento de suas necessidades espirituais.

Para coletarmos os dados para a pesquisa, faremos uma entrevista com você. Na entrevista queremos ouvir e registrar as suas necessidades durante a sua internação no hospital. Manteremos a sua identidade em segredo e não será possível identificar a sua resposta na análise dos dados ou quando esses forem publicados, uma vez que seu nome não aparecerá na pesquisa.

Este projeto foi aprovado pelo Comitê de Ética da Faculdade de Ciências da Saúde, sob o parecer $n^{\circ} 714.467$ de 09/07/2014, e nos comprometemos a desenvolver a pesquisa tal como foi aprovada. Ainda assim, você pode se retirar dela, mesmo após ter dado o seu consentimento, bastando para isto comunicar a um dos pesquisadores. Os dados serão publicados na forma de artigos científicos, comunicações ou painéis em eventos ou revistas científicas, independente de quais forem os resultados.

Para que você possa participar desta pesquisa, é necessário que assine as duas vias deste termo, ficando uma com você. E, caso deseje mais informações sobre a pesquisa ou mesmo fazer alguma denúncia, reclamação ou sugestão, por favor, entre em contato com o pesquisador responsável, Roberto Nascimento de Albuquerque, pelo número (61) 93025894 - celular, 32733807 (telefone do Departamento de Enfermagem ou ainda no Comitê de Ética da Faculdade de Ciências da Saúde (61) 31071947.

Caso você se sinta motivado e queira participar desta pesquisa, pedimos que assine abaixo, no espaço destinado ao sujeito da pesquisa, para que possamos usar as informações que você venha a nos fornecer.

Os gastos necessários para sua participação na pesquisa serão assumidos pelos pesquisadores. Fica também garantida a indenização em caso de danos, comprovadamente decorrentes da participação na pesquisa, conforme decisão judicial ou extrajudicial.

Brasília, 1 
Apêndice 3 - Roteiro para Entrevista Semiestruturada - Enfermeiros

UNIVERSIDADE DE BRASÍLIA

Enfermeiro(a):

Setor:

Tempo de atuação no setor:

1. Fale sobre o que entende sobre a integralidade do cuidado.

2. Considerando a sua vida profissional e pessoal, fale sobre a sua relação com a religião/espiritualidade.

3. Você considera que a vivência da dimensão espiritual é importante para o paciente? Como? Por quê?

4. Como você lida com a necessidade espiritual do paciente no dia a dia?

5. Conte-me um caso e ou experiência de sua vivência nessa área.

6. Você acha que os pacientes gostariam de ter as suas necessidades espirituais contempladas no plano de cuidado?

7. E você? Considera que essas necessidades devem ser atendidas pela enfermagem? 
Apêndice 4 - Roteiro para Entrevista Semiestruturada - Pacientes

UNIVERSIDADE DE BRASÍLIA

FACULDADE DE CIÊNCIAS DA SAÚDE

PROGRAMA DE PÓS-GRADUÇÃO EM ENFERMAGEM

\section{Apêndice 4 - Roteiro para Entrevista Semiestruturada - Pacientes}

Paciente:

Data:

Sexo: ( ) M

( ) F Idade:

Setor:

Tempo de Internação:

Diagnóstico médico:

\section{Religião/doutrina/crença:}

( ) Ateu

( ) Sem religião, mas espiritualizado (acredita em Deus, mas não pertence a nenhuma religião)

( ) Católico

( ) Protestante

( ) Espírita

( ) Evangélico

( ) Budista

( ) Umbandista

( ) Judeu

( ) Muçulmano

( ) Outra:

1. Qual a importância da religiosidade/espiritualidade na sua vida?

2. Você utiliza as suas crenças religiosidade/espiritualidade no enfrentamento da sua doença?

3. Suas necessidades espirituais têm sido atendidas pela equipe de enfermagem?

4. Gostaria de compartilhar suas necessidades espirituais com os membros da equipe de saúde? Como? Por quê?

5. Você gostaria de compartilhar comigo alguma vivência e ou experiência que teve relacionando suas crenças no período de sua doença/ e ou sua vida? 